\title{
Geology and Water Resources of Owens Valley, California
}

United States Geological Survey Water-Supply Paper 2370-B

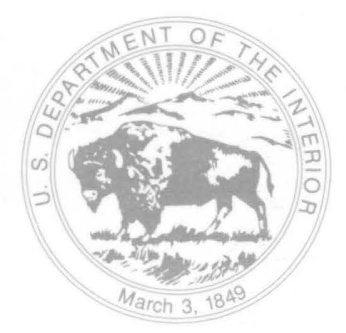


GEOLOGY AND WATER RESOURCES OF OWENS VALLEY, CALIFORNIA 


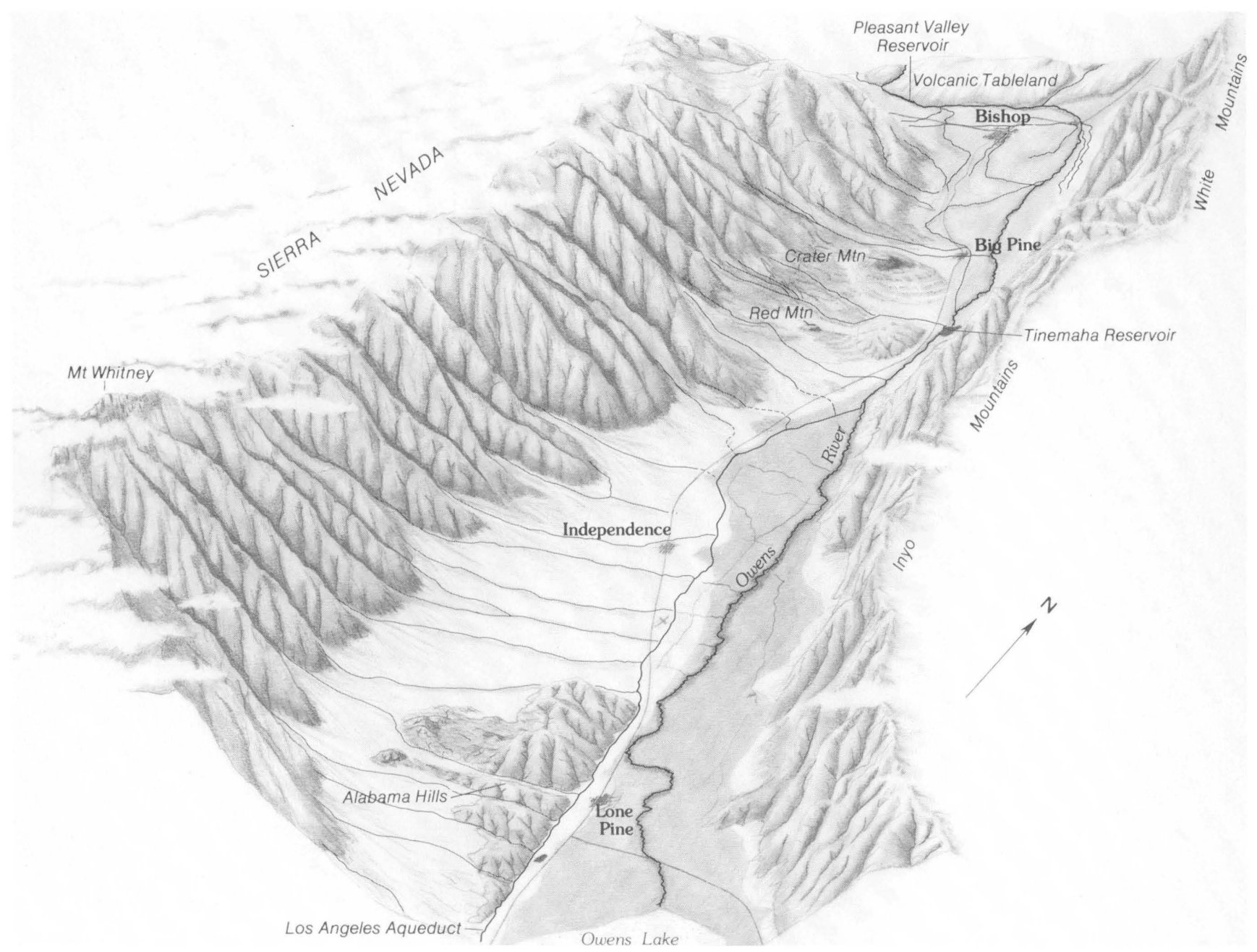

Vertically exaggerated perspective and oblique view of Owens Valley, California, showing the dramatic change in topographic relief between the valley and surrounding mountains. 
' Chapter B

\section{Geology and Water Resources of Owens Valley, California}

BY KENNETH J. HOLLETT, WESLEY R. DANSKIN, WILLIAM F. MCCAFFREY, and CARYL L. WALTI

Prepared in cooperation with

Inyo County and the

Los Angeles Department of Water and Power

U S. GEOLOGICAL SURVEY WATER-SUPPLY PAPER 2370

HYDROLOGY AND SOIL-WATER-PLANT RELATIONS IN OWENS VALLEY, CALIFORNIA 


\title{
U.S. DEPARTMENT OF THE INTERIOR
}

\author{
MANUEL LUJAN, JR., Secretary
}

\section{U.S. GEOLOGICAL SURVEY}

Dallas L. Peck, Director

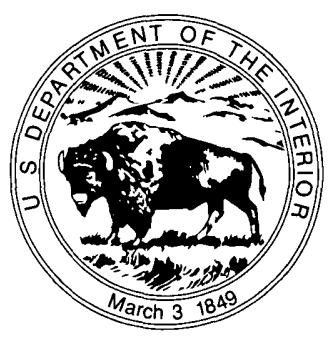

Any use of trade, product, or firm names

in this publication is for descriptive purposes only

and does not imply endorsement by the US Government

For sale by the

Books and Open-File Reports Section

U S Geological Survey

Federal Center, Box 25425

Denver, CO 80225

\section{Lıbrary of Congress Catalogıng-ın-Publıcatıon Data}

Geology and water resources of Owens Valley, Californı / by Kenneth J Hollett [et al]

p cm - (U S Geological Survey water-supply paper, 2370-B)

(Hydrology and soil-water-plant relations in Owens Valley, Calıfornıa, ch B) Includes biblıographical references

Supt of Docs no I 1913 2370-B

1 Geology-Calıfornı_-Owens River Valley 2 Water, UndergroundCalıfornı-Owens River Valley I Hollett, Kenneth J II Serıes III Series Hydrology and soıl-water-plant relatıons in Owens Valley, Calıfornı ch B QE90 09G46 1990

$$
5537^{\prime} 09794 ' 87-d c 20 \quad 90-13807
$$




\section{CONTENTS}

Abstract B1

Introduction B2

Purpose and scope $\mathbf{B 3}$

Physical settıng B3

Physiography $\mathbf{B 3}$

Clımate B5

Land and water use $\mathbf{B 5}$

Previous investigations B10

Acknowledgments $\quad$ B14

Geologic framework and its relation to the hydrologic system $\quad$ B14

Regional geologic settıng B14

Structure of Owens Valley B20

Bishop Basin B21

Owens Lake Basin B25

Hydrologic characteristics of geologic units B27

Bedrock B27

Valley fill B29

Depositional models B30

Alluvial fan deposits B31

Transition-zone deposits $\mathbf{B 3 3}$

Glacial and talus deposits $\mathbf{B 3 3}$

Fluvial and lacustrine deposits B34

Olıvine basalt of Bıg Pıne volcanıc field B35

Bishop Tuff B35

Water resources B36

Surface water B36

Source, routıng, and discharge $\mathbf{B 3 6}$

Tributary streamflow $\mathbf{B 3 6}$

Owens River and Los Angeles Aqueduct system $\quad$ B38

Lower Owens River B40

Canals and ditches B40

Water quality B41

Ground water B41

Aquifer system $\quad$ B42

Hydrogeologic framework $\mathbf{B 4 3}$

Source, occurrence, and movement of ground water $\quad \mathbf{B 4 7}$

Hydraulic characteristics of the hydrogeologic units $\quad \mathbf{B 4 7}$

Unit 1 characteristics B48

Unit 2 characteristics $\quad$ B51

Unit 3 characteristics $\quad$ B51

Faults B52

Water quality $\mathbf{B 5 3}$

Chemical quality of ground water for irrigation use $\mathbf{B 5 5}$

Chemical quality of ground water for public supply $\mathbf{B 5 6}$

Water budget $\mathbf{B 5 6}$

Precipitation and evapotranspiration $\mathbf{B 5 8}$

Tributary streams B59

Mountain-front recharge between tributary streams $\quad$ B61

Runoff from bedrock outcrops withın the valley fill $\quad \mathbf{B 6 2}$

Owens River and Los Angeles Aqueduct system $\quad$ B62

Lower Owens River B63

Lakes and reservoirs B64

Canals, ditches, and ponds $\quad$ B64 
Water resources-Contınued

Ground water-Contınued

Water budget-Contınued

Irrigation and watering of livestock $\quad \mathbf{B 6 6}$

Pumped and flowing wells B66

Summary $\quad$ B67

Springs and seeps $\quad$ B66

Underflow $\quad \mathbf{B 6 7}$

FRONTISPIECE

Vertically exaggerated perspective and oblique view of Owens Valley, Calıfornia, showing the dramatic change in topographic relief between the valley and surrounding mountains

PLATES

[Plates are in pocket]

1 Gravity profiles and geologic sections $A-A^{\prime}$ in Bishop, $B-B^{\prime}$ south of Bishop, $C-C^{\prime}$ near Big Pine, $D-D^{\prime}$ south of Tinemaha Reservoir, $E-E^{\prime}$ in Independence, $F-F^{\prime}$ in Lone Pine, $G-G^{\prime}$ south across Bishop, and $H-H^{\prime}$ southwest across Tinemaha Reservoir in Owens Valley, Calıfornı

2 Hydrogeologic sections $A-A^{\prime}$ in Bishop, $B-B^{\prime}$ south of Bishop, $C-C^{\prime}$ near Big Pine, $D-D^{\prime}$ south of Tinemaha Reservorr, $E-E^{\prime}$ in Independence, $F-F^{\prime}$ in Lone Pine, $G-G^{\prime}$ south across Bishop, and $H-H^{\prime}$ southwest across Tinemaha Reservoir in Owens Valley, Calıforna

FIGURES

1 Map showing location of Owens Valley and Mono Basın dranage areas and physiographic and cultural features $\mathbf{B} 4$

2 Photographs and computer-drawn views of landforms in Owens Valley, lookıng north along the axis, that emphasize the asymmetric geomorphic form of the valley B6

3 Map and graphs showing average annual precipitation for selected sites in the Owens Valley drainage basın $\mathbf{B 8}$

4 Graph showing average monthly arr temperatures at Bishop and Independence National Weather Bureau stations, 1931-85 B10

5 Map showıng distribution of land ownershıp in Owens Valley B11

6 Map showing distribution and areal coverage of sources of geologic, geophysic, and hydrologic data used in this report $\mathbf{B 1 2}$

7 Generalızed geologic map of the Owens Valley drainage basin B16

8 Diagram showing generalızed geologic column and hydrologic characteristics of the valley fill and bedrock units within the Bishop and Owens Lake Basins of the Owens Valley drainage basin area $\mathbf{B 1 8}$

9 Schematic block diagram of Owens Valley that illustrates the structural relation between the mountain blocks (horsts) and the valley trough (graben) B21

10 Map showing isostatic residual gravity anomalies, geologic structure, and inferred position of the structurally lowest part of the Owens Valley graben $\mathbf{B 2 2}$

11 Map showing structural division of Owens Valley into Bishop and Owens Lake Basins B24

12 Borehole geophysical logs of three wells in Bishop Basin and the geophysical correlation of major clay layers in the southern part of Bishop Basin B26

13 Photograph showing orientation of the Volcanic Tableland relative to the valley floor in the Bishop area $\mathbf{B 2 9}$ 
14 Schematic drawings of the generalized depositional models in the valley fill in Owens Valley $\mathbf{B 3 2}$

15 Photograph showing alıgnment of volcanic cones, rhyolitic dome, and springs along the faults in the Poverty Hills area of Owens Valley B36

16 Map showing Owens Valley draınage basin area and surface-drannage patterns for tributary streams, Owens River, and Owens River-Los Angeles Aqueduct system B37

17 Map showing areal extent of defined aquifer system, occurrence of unconfined and confined conditions, boundary conditions, configuration of potentiometric surface in hydrogeologic units 1 and 3, and direction of ground-water flow, spring $1984 \quad \mathbf{B 4 4}$

18 Map showing location of selected wells and springs sampled for water quality or used for analysis of aquifer characteristics, and approximate area of the Los Angeles Department of Water and Power well fields B49

19 Graph showing logarithmic plot of drawdown compared to $t / r^{2}$ for two observation wells south of Big Pine B52

20 Graph showing logarithmic plot of drawdown compared to time for an observation well south of Big Pine using match point for leaky confıned material B53

21 Trilınear diagram showing percentages of chemical constituents in well water and classification of major water types $\mathbf{B 5 5}$

22 Map showing water gains and losses to lower Owens River B65

TABLES

1 Approximate range of values of horizontal hydraulic conductivity and specific yield for subunits in the valley fill and bedrock in Owens Valley B30

2 Maxımum, mınımum, and mean annual discharge measured at base-of-mountains and Owens River-Los Angeles Aqueduct system gaging statıons for tributary streams in Owens Valley, water years 1935-84 B39

3 Maxımum, mınımum, and mean annual discharge of the Owens River-Los Angeles Aqueduct system and lower Owens River for selected periods of record B40

4 Chemical constituents and physical properties of water in Owens River downstream from Tinemaha Reservoir, water years 1974-85 $\mathbf{B 4 2}$

5 Chemical analyses of water from selected wells in Owens Valley B54

6 Ground-water budget of the Owens Valley aquifer system $\mathbf{B 5 8}$

7 Vegetation characteristics, water-level and precipitation data, and range in evapotranspiration estımates for selected sites in Owens Valley B60

8 Average annual rate of recharge between base-of-mountains and river-aqueduct gages for selected streams in Owens Valley $\mathbf{B 6 2}$ 


\title{
CONVERSION FACTORS
}

For readers who wish to convert measurements from the inch-pound system of units to the metric system of units, the conversion factors are listed below

\begin{tabular}{|c|c|c|}
\hline Multıply inch-pound unit & By & To obtain metric unit \\
\hline acre & 0405 & square hectometer $\left(\mathrm{hm}^{2}\right)$ \\
\hline acre-foot (acre-ft) & 0001233 & cubic hectometer $\left(\mathrm{hm}^{3}\right)$ \\
\hline acre-foot per year (acre-ft/yr) & 0001233 & cubic hectometer per year $\left(\mathrm{hm}^{3} / \mathrm{yr}\right)$ \\
\hline $\begin{array}{r}\text { acre-foot per year per mile } \\
{[(\text { acre-ft } / \mathrm{yr}) / \mathrm{ml}]}\end{array}$ & 00007663 & $\begin{array}{l}\text { cubic hectometer per year per kılometer } \\
{\left[\left(\mathrm{hm}^{3} / \mathrm{yr}\right) / \mathrm{km}\right]}\end{array}$ \\
\hline foot $(\mathrm{ft})$ & 03048 & $\operatorname{meter}(\mathrm{m})$ \\
\hline foot per day $(\mathrm{ft} / \mathrm{d})$ & 03048 & meter per day $(\mathrm{m} / \mathrm{d})$ \\
\hline foot per mile $(\mathrm{ft} / \mathrm{ml})$ & 01895 & meter per kılometer $(\mathrm{m} / \mathrm{km})$ \\
\hline foot per second $(\mathrm{ft} / \mathrm{s})$ & 03048 & meter per second $(\mathrm{m} / \mathrm{s})$ \\
\hline foot per year $(\mathrm{ft} / \mathrm{yr})$ & 03048 & meter per year $(\mathrm{m} / \mathrm{yr})$ \\
\hline square foot $\left(\mathrm{ft}^{2}\right)$ & 009294 & square meter $\left(\mathrm{m}^{2}\right)$ \\
\hline foot squared per day $\left(\mathrm{ft}^{2} / \mathrm{d}\right)$ & 00929 & meter squared per day $\left(\mathrm{m}^{2} / \mathrm{d}\right)$ \\
\hline cubic foot $\left(\mathrm{ft}^{3}\right)$ & 002832 & cubic meter $\left(\mathrm{m}^{3}\right)$ \\
\hline cubic foot per second $\left(\mathrm{ft}^{3} / \mathrm{s}\right)$ & 002832 & cubic meter per second $\left(\mathrm{m}^{3} / \mathrm{s}\right)$ \\
\hline gallon (gal) & 3785 & liter $(\mathrm{L})$ \\
\hline gallon per minute (gal/min) & 006308 & liter per second $(\mathrm{L} / \mathrm{s})$ \\
\hline inch (in) & 254 & millımeter $(\mathrm{mm})$ \\
\hline inch per year $(\mathrm{ln} / \mathrm{yr})$ & 254 & mıllımeter per year $(\mathrm{mm} / \mathrm{yr})$ \\
\hline mile $(\mathrm{ml})$ & 1609 & kllometer $(\mathrm{km})$ \\
\hline square mile $\left(\mathrm{ml}^{2}\right)$ & 2590 & square kılometer $\left(\mathrm{km}^{2}\right)$ \\
\hline pounds per square foot $\left(\mathrm{lb} / \mathrm{ft}^{2}\right)$ & 4882 & kılograms per square meter $\left(\mathrm{kg} / \mathrm{m}^{2}\right)$ \\
\hline
\end{tabular}

Temperature is given in degrees Fahrenheit $\left({ }^{\circ} \mathrm{F}\right)$, which can be converted to degrees Celsius $\left({ }^{\circ} \mathrm{C}\right)$ by the following equation

Temp ${ }^{\circ} \mathrm{C}=\left(\right.$ temp $\left.{ }^{\circ} \mathrm{F}-32\right) / 18$

Definitions

Rain year

Runoff year

Water year

Calendar year
July 1 through June 30

April 1 through March 31

October 1 through September 30

January 1 through December 31

\author{
Abbreviations used \\ $\mathrm{mg} / \mathrm{L}-$ milligram per liter \\ $\mathrm{mL}-$ milliliter \\ $\mathrm{mS} / \mathrm{cm}$-microsiemen per centımeter at $25^{\circ}$ Celsıus
}

\section{SEA LEVEL}

In this report, "sea level" refers to the Natıonal Geodetıc Vertıcal Datum of 1929 (NGVD of 1929)—a geodetıc datum derived from a general adjustment of the first-order level nets of both the United States and Canada, formerly called Sea Level Datum of 1929 


\title{
Geology and Water Resources of Owens Valley, California
}

\author{
By Kenneth J. Hollett, Wesley R Danskın, Wıllıam F McCaffrey, and Caryl L. Waltı
}

\begin{abstract}
Owens Valley, a long, narrow valley located along the east flank of the Sierra Nevada in east-central Calıfornı, is the main source of water for the city of Los Angeles The city diverts most of the surface water in the valley into the Owens River-Los Angeles Aqueduct system, which transports the water more than 200 miles south to areas of distribution and use Additionally, ground water is pumped or flows from wells to supplement the surface-water diversıons to the river-aqueduct system Pumpage from wells needed to supplement water export has increased since 1970, when a second aqueduct was put into service, and local concerns have been expressed that the ıncreased pumpage may have had a detrımental effect on the environment and the indıgenous alkalıne scrub and meadow plant communities in the valley The scrub and meadow communities depend on soil moisture derived from precipitation and the unconfined part of a multılayered aquifer system This report, which describes the hydrogeology of the aquifer system and the water resources of the valley, is one in a series designed to (1) evaluate the effects that groundwater pumpıng has on scrub and meadow communitıes and (2) appraise alternatıve strategies to mitıgate any adverse effects caused by, pumpıng

Two princıpal topographıc features are the surface expression of the geologic framework-the high, promınent mountaıns on the east and west sides of the valley and the long, narrow intermountain valley floor The mountaıns are composed of sedımentary, granıtıc, and metamorphıc rocks, mantled in part by volcanic rocks as well as by glacıal, talus, and fluvial deposits The valley floor is underlain by valley fill that consists of unconsolidated to moderately consolıdated alluvial fan, transition-zone, glacial and talus, and fluvial and lacustrine deposits The valley fill also includes interlayered recent volcanic flows and pyroclastıc rocks The bedrock surface beneath the valley fill is a narrow, steep-sided graben that is structurally separated Into the Bishop Basın to the north and the Owens Lake Basın to the south These two structural basıns are separated by (1) a bedrock high that is the upper bedrock block of an east-west normal fault, (2) a horst block of bedrock (the Poverty HIlls), and (3) Quaternary basalt flows and cınder cones that intercalate and Intrude the sedımentary deposits of the valley fill The resultıng structural separatıon

of the basıns allowed separate development of fluvial and lacustrine depositıonal systems in each basın

Nearly all the ground water in Owens Valley flows through and is stored in the saturated valley fill The bedrock, which surrounds and underlies the valley fill, is virtually impermeable Three hydrogeologic units compose the valley-fill aquifer system, a defined subdivision of the ground-water system, and a fourth represents the valley fill below the aquifer system and above the bedrock The aquifer system is divided into horizontal hydrogeologic units on the basıs of either (1) uniform hydrologıc characteristıcs of a specific lithologic layer or (2) distribution of the vertıcal hydraulic head Hydrogeologic unit 1 is the upper unit and represents the unconfined part of the system, hydrogeologic unit 2 represents the confınıng unit (or units), and hydrogeologic unit 3 represents the confined part of the aquifer system Hydrogeologic unit 4 represents the deep part of the ground-water system and lies below the aquifer system Hydrogeologıc unit 4 transmits or stores much less water than hydrogeologıc unıt 3 and represents either a moderately consolidated valley fill or a geologic unit in the valley fill defıned on the basıs of geophysıcal data

Nearly all the recharge to the aquifer system is from infiltration of runoff from snowmelt and rainfall on the Sierra Nevada In contrast, little recharge occurs to the system by runoff from the White and Inyo Mountains or from direct precipitation on the valley floor Ground water flows from the margins of the valley toward the center of the valley, the ground water then flows south to the termınus of the system at Owens Lake (dry) Ground water flows south from Bishop Basın to Owens Lake Basın through the "narrows" that constrict the flow opposite Poverty Hills The aquifer system in the northern part of Owens Lake Basın is divided into east and west halves by the barrier effect caused by the Owens Valley fault Discharge from the aquifer system is prımarıly by pumpage and evapotranspiration, and to a lesser extent by flowing wells, springs, underflow, and leakage to the Owens River-Los Angeles Aqueduct system Withdrawals from pumped or flowing wells are the largest component of discharge and account for about 50 percent of the outflow from the system Transpiration by scrub and meadow plant communities, and to a lesser extent by irrigated alfalfa pasture, accounts for about 40 percent of the system's discharge
\end{abstract}


Natural hydraulic conductivity ranges from less than 400 to about 12,000 feet per day in the basalt flows, the more permeable material in the aquifer system Where the basalts are fractured by explosıves and drillıng technıques, actual transmissivities can be greater than 1 million feet squared per day Hydraulic conductivities in sedimentary deposits of the aquifer system range from less than a few feet per day in lacustrıne clays to more than 300 feet per day ın gravel strıngers and beach deposits in the transition zone between alluvial fan deposits and fluvial and lacustrine deposits

Degree of confinement in the aquifer system generally increases to the south and east in both the Bishop and Owens Lake Basıns The vertıcal hydraulıc gradient across hydrogeologıc unit 2 and confınıng beds in hydrogeologıc units 1 and 3 is a function of (1) the asymmetric recharge and hydraulic head created by the domınant recharge from Sierra Nevada runoff and (2) the areal extent and thickness of the confınıng beds Although most of the pumpage is from hydrogeologic unit 3, some coincident drawdown has been recorded in nonpumped wells that tap unit 1 Drawdown in hydrogeologic unit 1 is a function of changes in (1) lateral flow through hydrogeologic unit 1, (2) upward flow of ground water through the confinıng beds, (3) downward leakage of water from hydrogeologic unit 1 to unit 3 through wells, (4) direct withdrawal from well intervals open to hydrogeologic unit 1 , and (5) ıncreased evapotranspıratıon

The water in the aquifer system is generally of excellent quality for public supply and irrigation, with the exception of water stored in thick sequences of lacustrıne sılts and clays near Owens Lake The water is principally a calcıum bicarbonate type, and dissolved-solıds concentrations range from approxımately 104 to 325 milligrams per liter Water in the lacustrıne sedıments of Owens Lake (dry) is a sodıum bıcarbonate type, and dissolved-solıds concentrations are about 5,400 milligrams per liter

\section{INTRODUCTION}

Owens Valley, a long, narrow valley located on the east flank of the Sierra Nevada in east-central Calıfornia (frontispiece), is the main source of water for the city of Los Angeles The city diverts most of the surface water of the valley into the Owens River-Los Angeles Aqueduct system (subsequently referred to in this report as "the riveraqueduct system"), which transports the water more than $200 \mathrm{mi}$ south to areas of distribution and use

Additionally, ground water is pumped or flows from wells and then is discharged into the river-aqueduct system Pumpage varies from year to year and is dependent on the avallability of surface-water supplies Since 1970, when a second aqueduct from Owens Valley to Los Angeles was put into service, additional ground water has been pumped as a result of the increased export capacity

Outflow of ground water also occurs naturally in Owens Valley The principal mechanısms include transpiration by indigenous alkalıne scrub and meadow plant communities (Sorenson and others, 1989, p C2), evaporation from soil in shallow-ground-water areas, and discharge from springs Approxımately 73,000 acres of the valley floor is covered by phreatophytıc (Dileanıs and Groeneveld, 1989, p D2) alkalıne plant communitıes These plant communıties have an annual evapotranspiration loss from the ground-water system of about 40 percent the annual natural recharge to the valley In the early 1970's, the phreatophytic plants covered about the same acreage, and conditıons were similar to those observed between 1912 and 1921 (Griepentrog and Groeneveld, 1981) In 1981, a loss of 20 to 100 percent of the plant cover on about 26,000 acres was noted (Griepentrog and Groeneveld, 1981) This reduction was postulated to be a response to the increased pumpage of ground water and changes in surface-water use Considerable public concern was expressed because of the environmental impact and the related loss of recreational activities and wildlife habitats

This study was undertaken as part of a much larger effort In 1982 the U S Geological Survey, in cooperation with Inyo County and the Los Angeles Department of Water and Power, began a series of comprehensive studies to define the ground-water system in Owens Valley and to determine the effects of ground-water withdrawals on native vegetation These studies are discussed more fully by Hollett (1987) and Danskın (1988) The results of the studies, as well as a comprehensive summary, are presented in a US Geological Survey Water-Supply Paper series as the interpretive products of the studies become avallable The series, "Hydrology and Soil-Water-Plant Relatıons in Owens Valley, Calıfornı," consists of eight chapters as follows

A A summary of the hydrologic system and soil-water-plant relations in Owens Valley, California, 1982-87, with an evaluation of management alternatives,

B Geology and water resources of Owens Valley, Calıfornia (this report),

C Estımatıng soil matrıc potentıal in Owens Valley, Calıfornia,

D Osmotic potential and projected drought tolerances of four phreatophytic shrub species in Owens Valley, Calıfornia,

E Estımates of evapotranspiratıon in alkalıne scrub and meadow communities of Owens Valley, Calıfornia, using the Bowen-ratio, eddycorrelation, and Penman-combınation methods,

$\mathrm{F}$ Influence of changes in soil water and depth to ground water on transpiration and canopy of alkalıne scrub communitıes in Owens Valley, Californıa,

G Vegetation and soll-water responses to precipitation and changes in depth to ground water in Owens Valley, Calıfornıa, and

$\mathrm{H}$ Numerical evaluation of the hydrologic system and selected water-management alternatives in Owens Valley, Calıfornıa 


\section{Purpose and Scope}

This report describes the geology and water resources of Owens Valley with an emphasis on the ground-water-flow system The development and use of the ground-water resources is best achieved through an understanding of the geologic framework and its effect on the response of the hydrologic system to climate, plant community water demand, and water-supply development This report provides the necessary conceptual geologic framework and description of the hydrologic system for the boundary and initial conditions used in the companion report on the numencal evaluation of the hydrologic system (chapter $\mathrm{H}$ )

The scope of this report includes a thorough literature search and compilation of published and unpublished geologic and hydrologic information to determine what additonal field studies were needed and to define the structural and geologic framework of the valley Additional background for the report included water-level measurements, streamflow records, water-quality data, pumping data, aquifer test data, drillers' logs, borehole geophysical logs, and reports from the cooperatıng agencies Prelımınary ground-water-flow models (Yen, 1985, Danskın, 1988, Guymon and Yen, 1990) were used to evaluate the adequacy of background data, guide the design of new field studies, and help identify the hydrologically sensitive parts of the conceptual model of the flow system New field studies, which included test drilling, examination of drill cuttıngs, surface and borehole geophysical surveys, and reconnaissance geologic mapping, were used to refine the hydrogeologic knowledge of the valley New water-level data, partıcularly multılevel hydraulıc-head measurements and pumping and aquifer test data, were used to improve the definition of the conceptual ground-water-flow system Data collected as a part of a separate study by the Los Angeles Department of Water and Power and Inyo County also were used to better define the ground-water system

\section{Physical Setting}

Owens Valley is within the Owens Valley drainage basin area (fig 1) and occupies the western part of the Great Basin section of the Basin and Range province (Fenneman, 1931, Fenneman and Johnson, 1946) The Great Basin section typically consists of linear, roughly parallel, north-south mountain ranges separated by valleys, most of which are closed drainage basins (Hunt, 1974) The Owens Valley ground-water basin extends from Hawwee Reservoir in the south, northward to include Round, Chalfant, Hammil, and Benton Valleys (fig 1) The Owens Valley drainage area, about 3,300 $\mathrm{ml}^{2}$, includes the mountain areas that extend from the crest of the Sierra Nevada on the west to the crest of the White and Inyo Mountains on the east Also included are part of Haiwee Reservorr and the crest of the Coso Range on the south and the crest of the volcanic hills and mountains that separate Mono Basin and Adobe Valley from Long and Chalfant Valleys and the Volcanic Tableland (fig 1) The drainage area includes Long Valley, the headwaters area of the Owens River (fig 1)

\section{Physiography}

Physiographically, Owens Valley contrasts sharply with the prominent, jagged mountains that surround it (fig 2) These mountains - the Sierra Nevada on the west and the White and Inyo Mountains on the east-rise more than $9,000 \mathrm{ft}$ above the valley floor The valley, characterized as high desert rangeland, ranges in altitude from about 4,500 $\mathrm{ft}$ north of Bishop to about 3,500 $\mathrm{ft}$ above sea level at Owens Lake (dry)

The valley floor is characterized by alkalıne scrub and meadow plant-covered flat terrain, incised by one major trunk stream, the Owens River, which meanders south through the valley Numerous tributaries drain the east face of the Sierra Nevada and have formed extensive coalesced alluvial fans along the west side of the valley These fans form prominent alluvial aprons that extend east nearly to the center of the valley (fig 2) In contrast, the tributary streams and related alluvial fans are solitary forms with no contınuous apron on the east side of the valley Consequently, the Inyo and White Mountains rise abruptly from the valley floor (fig 2) As a result of this asymmetrical alluvial fan formation, the Owens River flows on the east side of the valley

Owens Valley is a closed drannage system Prior to the construction of the Los Angeles Aqueduct, water that flowed from the mountains as a result of precipitation was transported by the tributary streams to the Owens River in both Long and Owens Valleys and then south to Owens Lake, the natural termınus of the drainage system The granitic and volcanic Coso Range, which has a poorly defined circular form, unlıke the linear forms of the Sierra Nevada or White and Inyo Mountains (Duffield and others, 1980), forms a barner at the south end of Owens Valley (fig 1) The Coso Range prevents downvalley streamflow at Owens Lake (dry) and blocks any significant natural ground-water outflow from the lower end of the valley Prior to 20th-century development in Owens Valley, Owens Lake was a large body of water that covered more than $100 \mathrm{mi}^{2}$ and exceeded a depth of $20 \mathrm{ft}$ Diversion of streamflow for irngation uses in the early 1900's and to the nver-aqueduct system after 1913, however, altered the water budget of the lake Evaporation now exceeds inflow except in very wet years, and the lake is presently (1988) a playa

The river-aqueduct system in the Owens Valley drainage area is defined for purposes of this report as (1) the Owens River from its headwaters in Long Valley to the intake of the Los Angeles Aqueduct, (2) Mono Craters Tunnel and streamflow diverted from Mono Basin, (3) the Los Angeles Aqueduct from the intake to Hawwee Reservorr, and (4) all reservoirs along the defined system (fig 1) The actual Owens River between the aqueduct intake and 


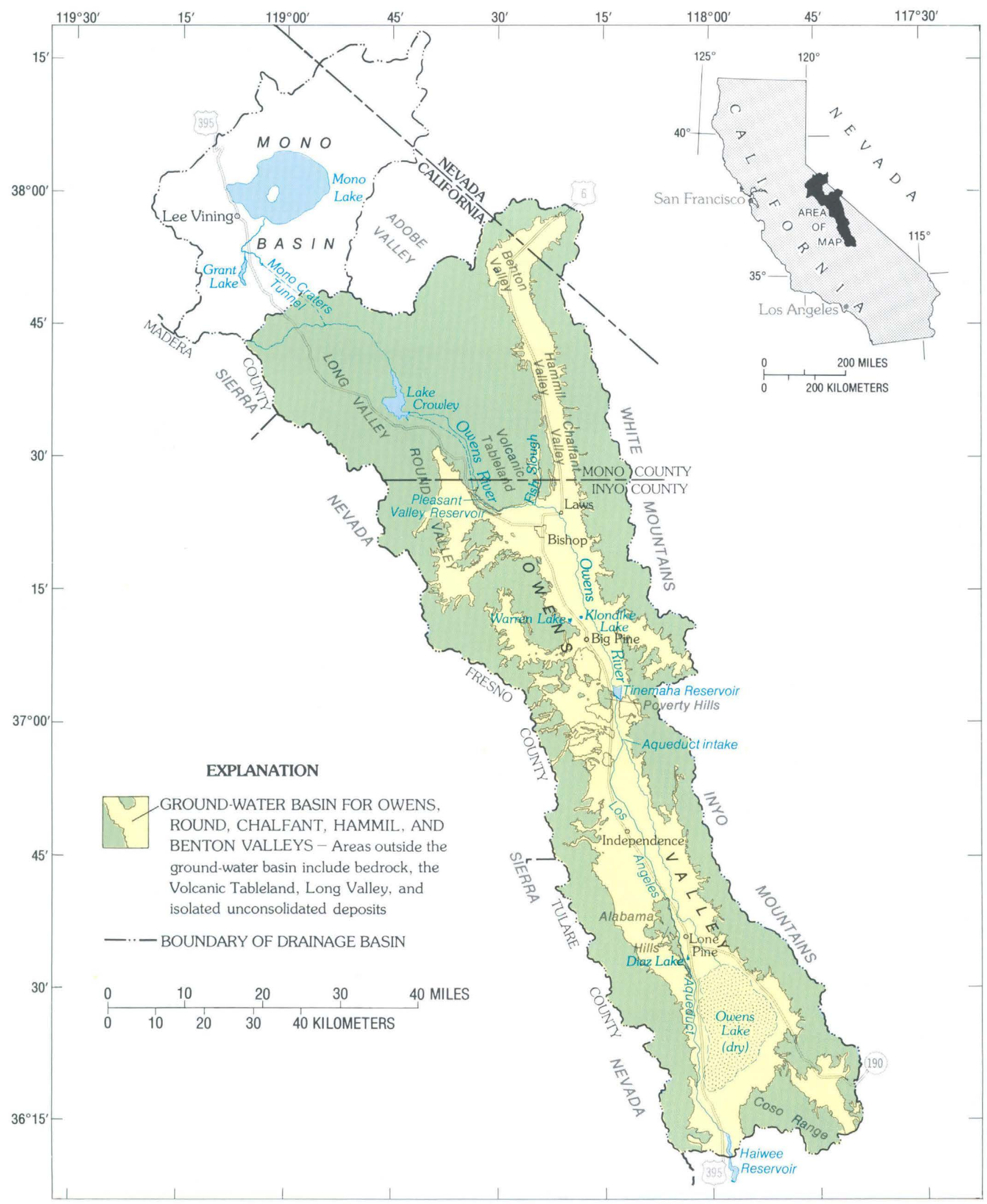

Figure 1. Location of Owens Valley and Mono Basin drainage areas and physiographic and cultural features. 
Owens Lake (dry), which is informally referred to as the "lower Owens River," is not a part of the river-aqueduct system Flow in the Owens River upstream of the aqueduct intake (fig 1) is an integral part of the river-aqueduct system and is controlled by releases from Pleasant Valley and Tinemaha Reservoirs (fig 1) Flow in the lower Owens River is dependent on releases from the river-aqueduct system or discharge from the ground-water system

There are several reservoirs along the course of the river-aqueduct system These water bodies, principally Grant Lake, Lake Crowley, and Pleasant Valley, Tinemaha, and Haiwee Reservoirs ( $f_{1} g$ ), are used primarıly to regulate flows and to store water for the river-aqueduct system

\section{Climate}

The climate in Owens Valley is greatly influenced by the Sierra Nevada Precipitation is derived chiefly from moisture-laden airmasses that originate over the Pacific Ocean and move eastward Because of the orographic effect of the Sierra Nevada, a rain shadow is present east of the crest, precipitation in the valley and on the White and Inyo Mountains and Coso Range is appreciably less Consequently, the climate in the valley is semiarid to arid and is characterized by low precipitation, abundant sunshine, warm temperatures, frequent winds, moderate to low humidity, and high potential evapotranspiration

About 60 to 80 percent of the average annual precipitation in the drainage area falls as snow or rain in the Sierra Nevada, primarily durng the period October to April A lesser amount falls durnng summer thunderstorms Average annual precipitation at the crest of the range generally exceeds $40 \mathrm{in}$, whereas on the valley floor the average annual precipitation is approximately 5 to 6 in (Groeneveld and others, 1986a, b, Duell, 1990) (fig 3) Conversely, the White and Inyo Mountains and Coso Range receive approximately 7 to $14 \mathrm{in} / \mathrm{yr}$ Graphs of average annual precipitation for selected sites in the drainage area show the large vanability in precipitation from site to site and year to year (fig 3) The lines of equal precipitation (fig 3), however, represent an average of more than 50 years of partial and contınuous record and represent the spatial distribution of average annual precipitation for the period of record (Los Angeles Department of Water and Power, 1972, 1976, 1978, 1979, National Weather Bureau, written commun , 1983, Duell, 1990)

Air temperature in the valley varies greatly Contınuous records from 1931 to 1985 at Bishop and Independence National Weather Bureau stations indicate that average monthly air temperature ranges from near freezing in the winter to more than $80^{\circ} \mathrm{F}$ in the summer (fig 4) Da1ly changes in temperature, however, can span more than $50^{\circ} \mathrm{F}$ Measured winter temperatures fall as low as $-2^{\circ} \mathrm{F}$, whereas summer temperatures have been measured at $107^{\circ} \mathrm{F}$, typ1cal of a semiarid to arid climate The average monthly air temperatures are generally 1 to $3^{\circ} \mathrm{F}$ cooler in the Bishop area than in the Independence area but the seasonal pattern and amplitudes are similar (fig 4)

Wind direction generally fluctuates north and south along the center of the valley Studies by Duell (1990) during the years 1984 through 1985 indicated that windspeeds ranged from zero to more than $30 \mathrm{~m} / \mathrm{h}$ However, windspeed was found to be highly variable in the valley and no seasonal trend was evident

Moisture content and relative humidity of air are $1 \mathrm{~m}$ portant factors in energy transport Actual water-vapor content in air can be expressed in terms of vapor density In Owens Valley, average vapor density in 1984 was about $45 \mathrm{~g} / \mathrm{m}^{3}$ (grams per cubic meter), and one-half-hour average vapor density ranged from $05 \mathrm{~g} / \mathrm{m}^{3}$ (during winter months) to $174 \mathrm{~g} / \mathrm{m}^{3}$ (in August) (Duell, 1990) Relative humıdity generally ranges from 6 to 100 percent and averages less than 30 percent durnng the summer months and more than 40 percent durng the winter months (Duell, 1990)

Estımates of average annual evapotranspiration for 1984 and 1985, which were calculated from site-specific micrometeorological data, ranged from 12 in in alkalıne scrub plant communities to 41 in in alkalıne meadow plant communities (Duell, 1990) Plant studies by Groeneveld and others (1986a, b) indicated that estımates of transpiration by porometry methods nearly equal but are less than the average annual evapotranspiration estımated by micrometeorological methods They further concluded that transpiration, not evaporation, accounts for most of the water lost from the scrub and meadow plant communities of Owens Valley on the basis of their studies and the one by Duell (1990) The evapotranspiration rate is approximately twice the annual precipitation rate from scrub plant communities and eight times the rate for meadow plant communities

\section{Land and Water Use}

Most of the land in the Owens Valley drainage basin area is owned by either the US Government or the Los Angeles Department of Water and Power (fig 5) Significantly less land is owned by municipalities or private citizens U S Government lands, etther Forest Service or Bureau of Land Management, are generally located in the mountains and along the edge of the mountains or on the Volcanic Tableland (fig 5) Of the 307,000 acres owned by the Los Angeles Department of Water and Power in Owens Valley and Mono Basin drainage basins, most of the land $(240,000$ acres) is located on the valley floor of Owens Valley

The major activities in the valley are livestock ranching and tourism About 190,000 acres of the valley floor is leased by the Los Angeles Department of Water and Power to ranchers for grazıng and about 12,400 additional acres is leased for growing alfalfa pasture Access to most lands in the mountains and valley is open to the public, and tens of thousands of people each year utilize the many natural recreational benefits such as huntıng, fishıng, skıng, and camping 


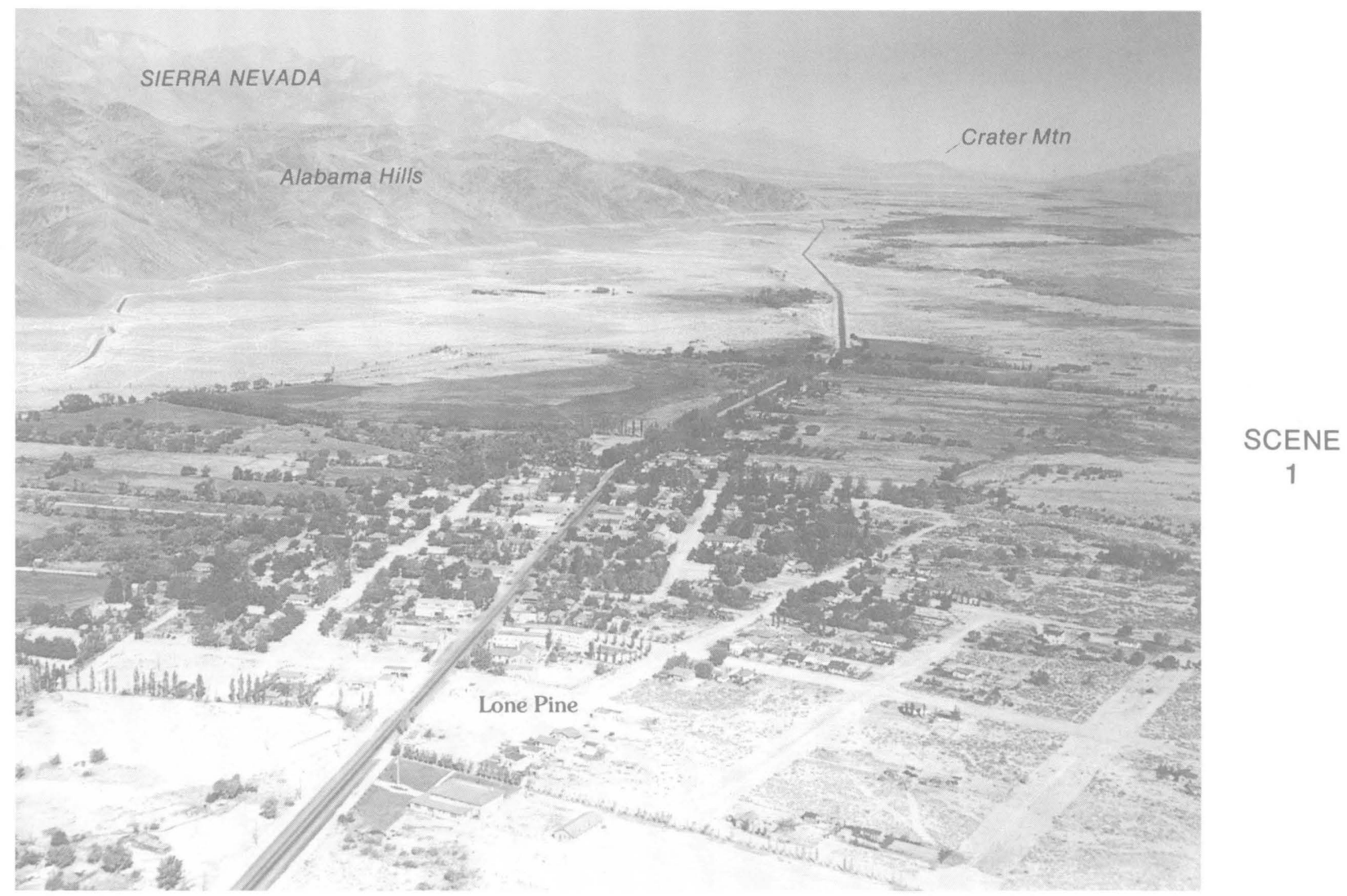

Figure 2. Landforms in Owens Valley, looking north along the axis, that emphasize the asymmetric geomorphic form of the valley (photographs by Spence Air Photo Company, August 1931, by permission of Geography Department, University of California, Los Angeles).

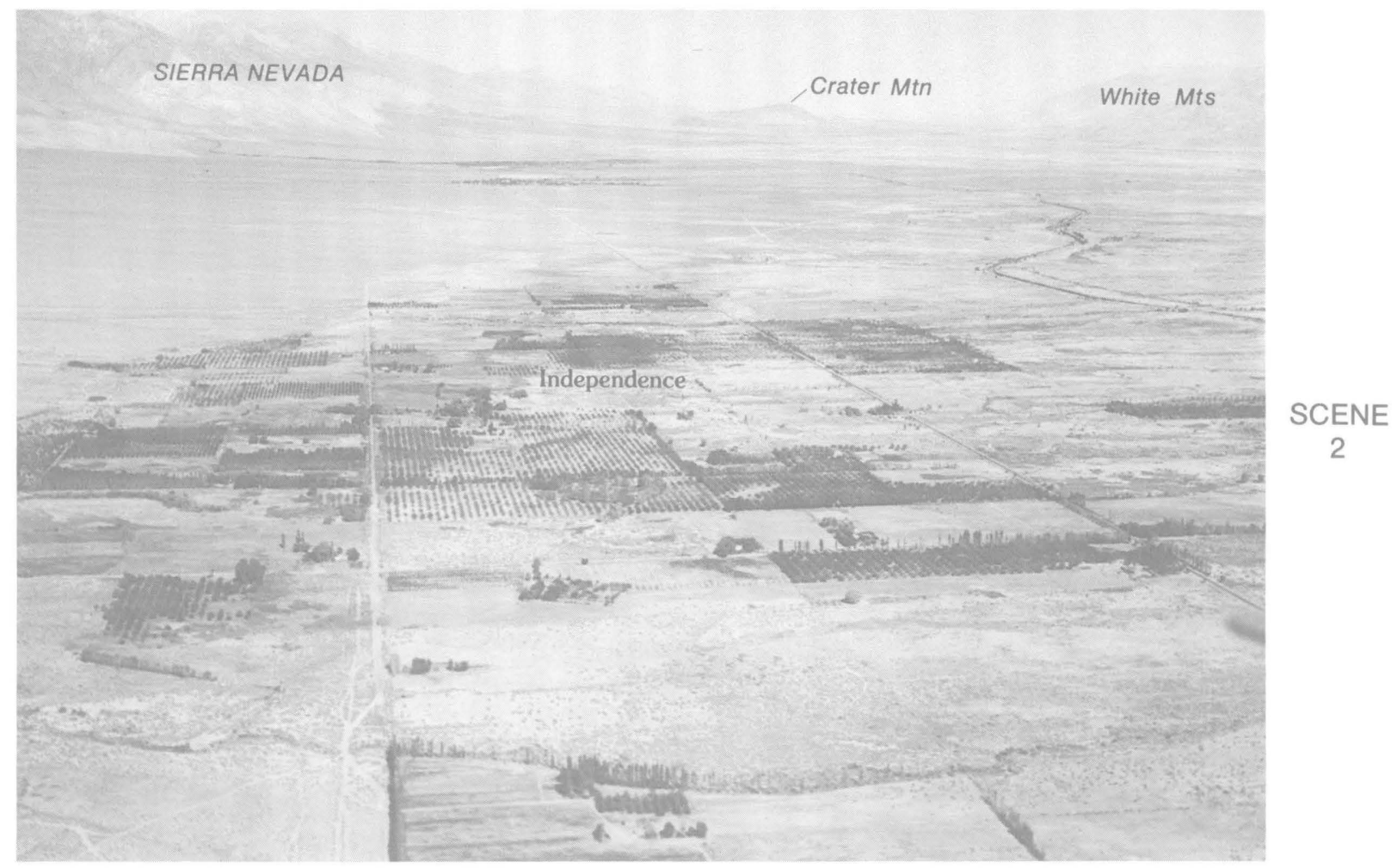

Figure 2. Continued. 


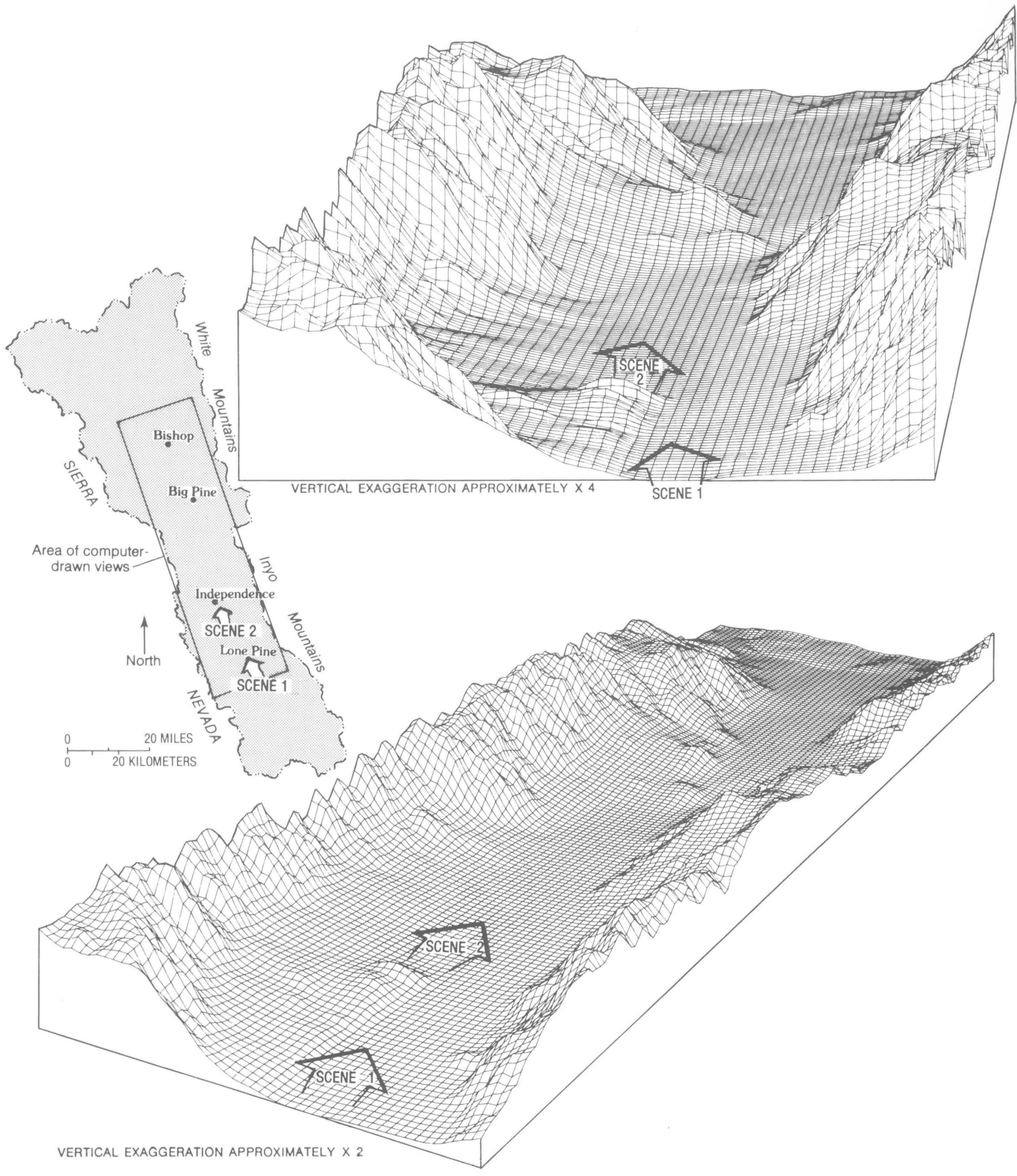

Figure 2. Continued. 


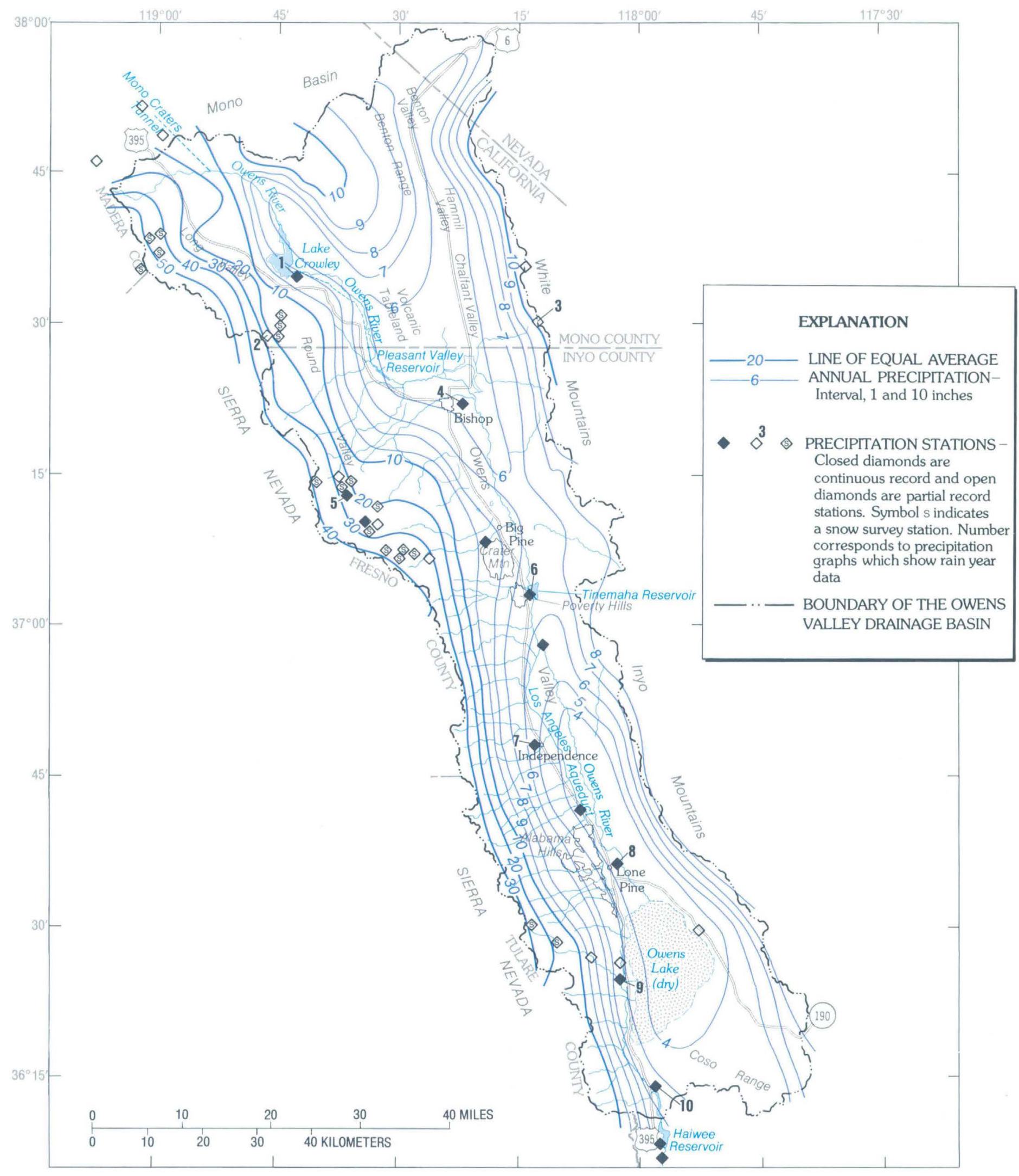

Figure 3. Average annual precipitation for selected sites in the Owens Valley drainage basin (data from Los Angeles Department of Water and Power, written commun., 1986; map modified and updated from Stetson, Strauss, and Dresselhaus, consulting engineers, written commun., 1961). 
Water used within the valley is available either from surface-water diversions or ground-water pumping. About $1,200-2,000$ acre- $\mathrm{ft} / \mathrm{yr}$ of ground water is supplied to the four major towns in the valley-Bishop, population 8,700; Big Pine, population 700; Independence, population 700; and Lone Pine, population 1,200. Other invalley use of water is for Indian reservations, stockwater, and irrigation of pastures, and for cultivation of alfalfa. Fish Springs and Blackrock fish hatcheries (fig. 5) rely on ground water. The Mount Whitney fish hatchery (fig. 5) uses surface water diverted from tributary runoff from the Sierra Nevada. A number of private wells in the valley, which are not maintained or monitored by the Los Angeles Department of Water and Power, are used mostly for domestic water supply, primarily at Mount Whitney fish
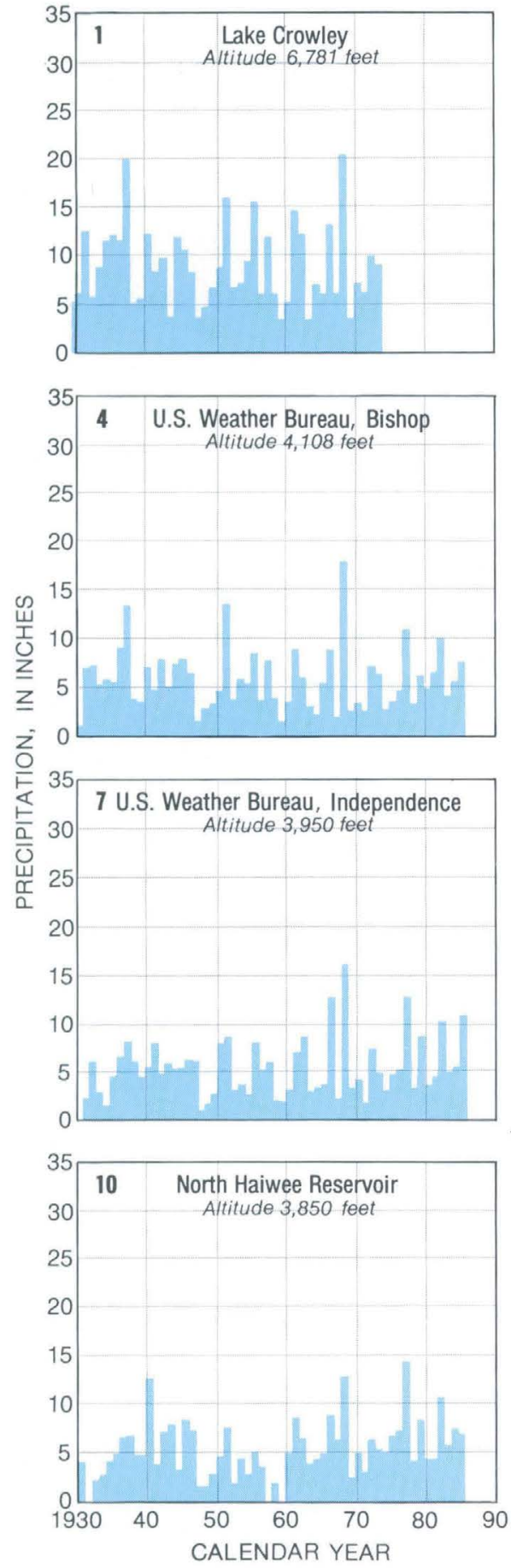

Figure 3. Continued.
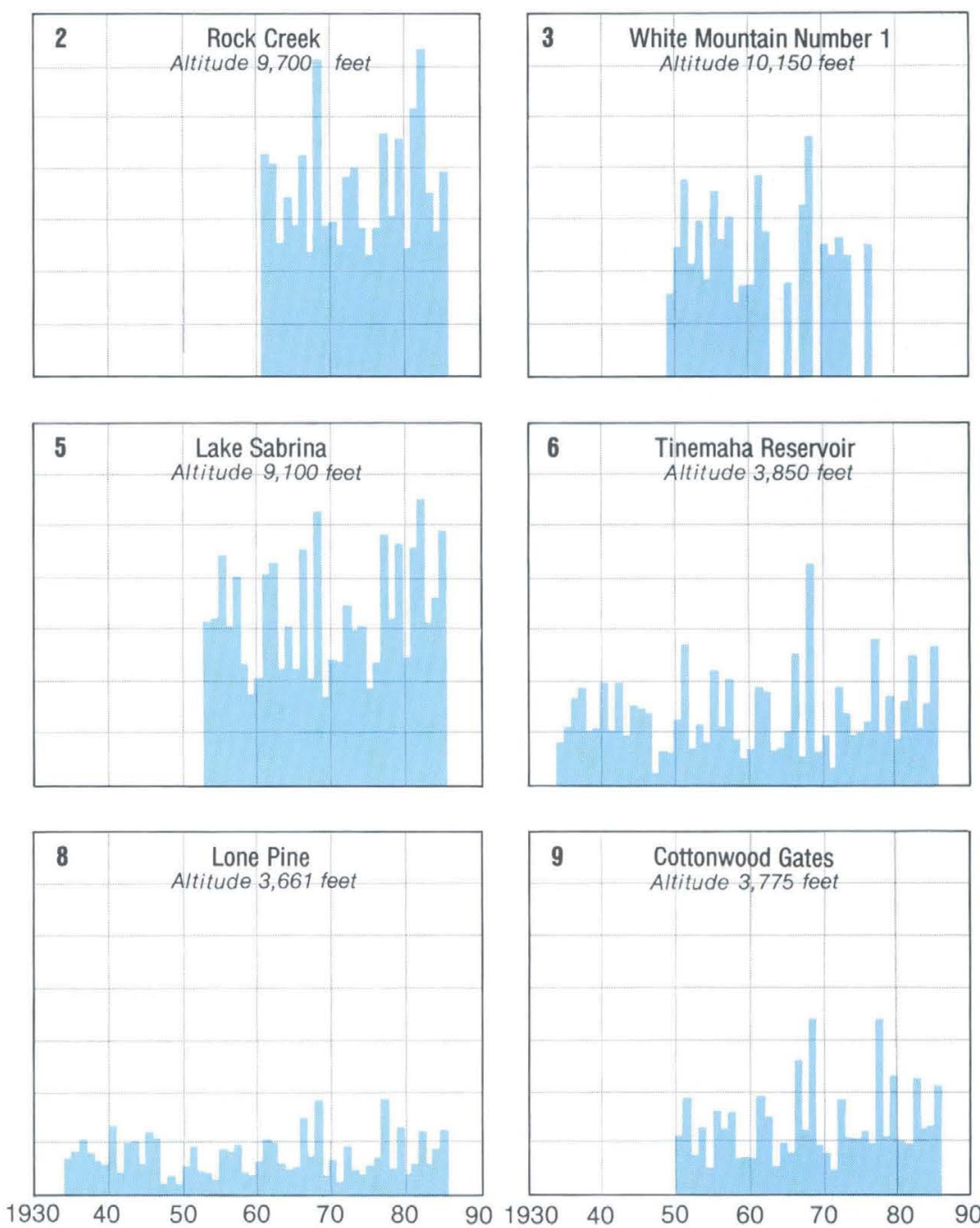

CALENDAR YEAR 
hatchery, isolated ranches, in Bishop, and on the four small Indian reservations in the valley The reservations are about 1 $\mathrm{mi}^{2}$ or less in size and are located near Bishop, Big Pine, north of Independence, and Lone Pine (fig 5)

\section{Previous Investigations}

The geology and hydrology of Owens Valley have been studied extensively since the late 1800's (fig 6) Because of extensive faulting, glaciation, volcanısm, and the presence of economic minerals and geothermal resources, the geologic history of the area has been a subject of contınuing interest and debate

Investigations prior to 1900 generally examined the geologic structure of the valley and proposed a geologic history for some of the major features (Walcott, 1897) At the turn of the century, the number of geologic investigations increased These were related to quantification and understanding of mineral occurrence and to the regional geology (G E Balley, 1902, Spurr, 1903, Trowbridge, 1911, Gale, 1915, Knopf, 1918, Hess and Larsen, 1921) As an economic resource, tungsten contınued to be the subject of further geologic studies in the Bishop mining district from 1934 to 1950 (Lemmon, 1941, Bateman and others, 1950) During the late 1950's and early 1960 's, there was a resurgence in geological investigations, both detailed and regional studies These studies were aimed at further mineral assessment, understanding crustal evolution and tectonics, and evaluation of geothermal resources along the eastern front of the Sierra Nevada As a result of these numerous studies, geologic quadrangle maps were completed for nearly all parts of the Owens Valley drainage basin area (fig 6) In addition, comprehensive regional structural and geo-

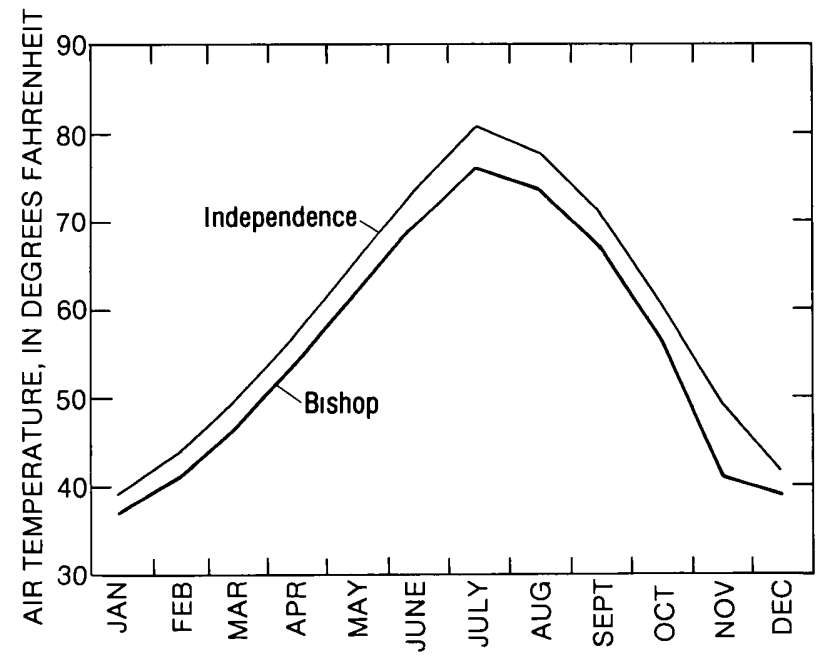

Figure 4. Average monthly air temperatures at Bishop and Independence Natıonal Weather Bureau statıons, 193185 (Los Angeles Department of Water and Power, written commun , 1985, as modified by Duell, 1990) physical studies of the Owens Valley region (Pakıser and others, 1964) and the Bishop and Volcanic Tableland area (Bateman, 1965) were conducted Numerous small scale, topical studies, primarily by universities, concerning geologic history and stratigraphy also have been completed The geological investigations in the Owens Valley region have generally been supported by strong public interest in volcanic hazards and geothermal energy assessment, plate tectonic implications of the Sierra Nevada, recent volcanism, and seismicity Selected discussions on regional tectonism in the Owens Valley region can be found in Oliver (1977), Stewart (1978), Prodehl (1979), and Blakely and McKee (1985)

Hydrologic investigations have paralleled geologic studies since the early 1900's because of the abundance of water in an otherwise arid region W T Lee (1906) and C H Lee (1912 and 1932) conducted prelımınary hydrologic investigations and documented conditions in part of Owens Valley prior to the diversion of surface water to Los Angeles, which began in $1913 \mathrm{CH}$ Lee (1912) divided Owens Valley on the basis of topography into four groundwater regions Long Valley, Bıshop-Bıg Pine, Independence, and Owens Lake Conkling (1921) summarized the avallability and use of water in Mono Basin and Owens Valley in order to evaluate the potential export of water from Mono Basin to Owens Valley Tolman (1937) recognized that the north and south parts of Owens Valley displayed different hydrogeologic characteristics He conceptually modeled the hydrologic relation of the ground-water flow from the alluvial fans to lacustrine sediments, and he noted that members of the Bishop Tuff buried in the sediments near Bishop were important water-bearing formations

As demand for water in Los Angeles increased, the Los Angeles Department of Water and Power collected large quantities of data on streamflow and ground-water pumpage throughout much of the valley Although most of these data have not been published, four summaries are avallable including three versions of an environmental impact report (Los Angeles Department of Water and Power, 1972, 1976, 1978, 1979) and reports associated with the construction and maintenance of the aqueduct (Los Angeles Board of Publıc Service Commissioners, 1916, Los Angeles Department of Water and Power, written commun, 1913-87) Calıfornia Department of Water Resources (1960) attempted to calculate the quantity of water in the valley that could be used for various recreational activities D E Williams (1969) investigated methods for increasing ground-water storage and developed a mathematical ground-water-flow model for a part of the south half of Owens Valley P B Willams (1978) used a regression model to analyze the relation between water-level declınes, precipitation, and ground-water pumpage Hardt (1980) summarized current understanding of the multilayer, ground-water system in the valley and answered hydrologic questions that remained unresolved Griepentrog and Groeneveld (1981) investigated the 


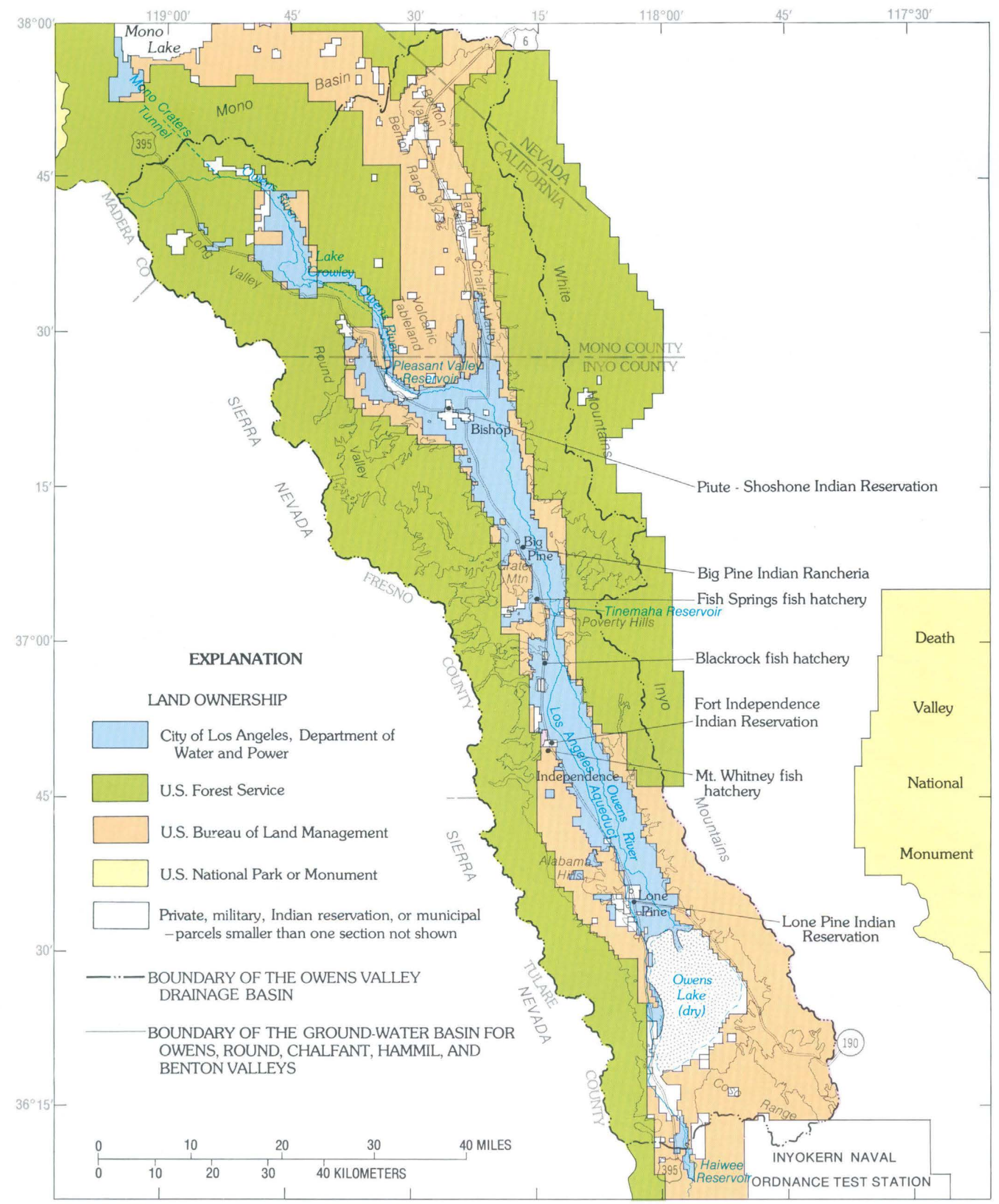

Figure 5. Distribution of land ownership in Owens Valley. Only major parcels are shown. Isolated, privately owned parcels less than one section (640 acres) are not shown (modified from U.S. Bureau of Land Management, 1976a, b, c and 1978a, b, c). 


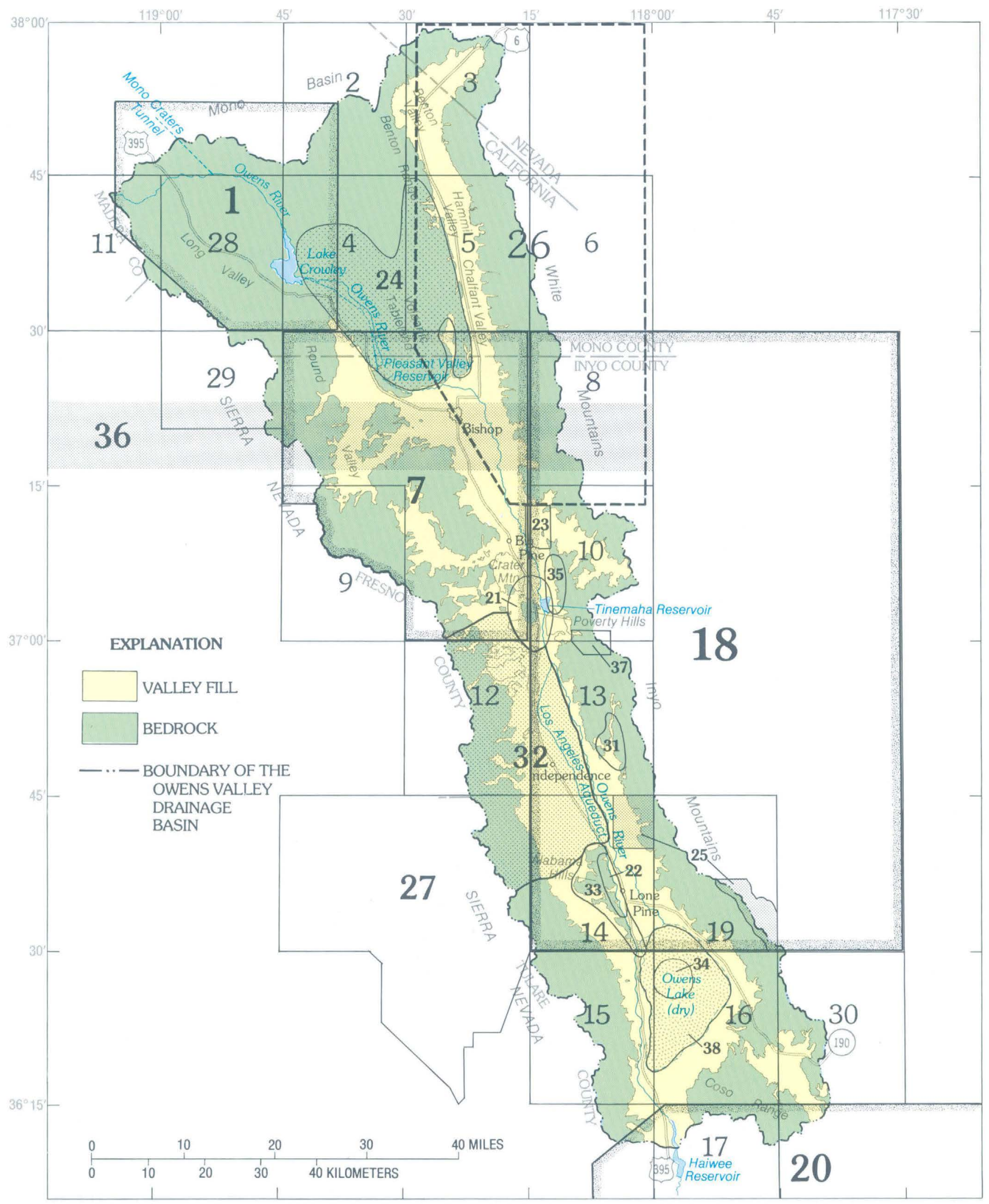

Figure 6. Distribution and areal coverage of sources of geologic, geophysic, and hydrologic data used in this report. 
hydrology of the valley and the impacts of recent waterlevel declines on the valley plant communities ,

Yen (1985) and Guymon and Yen (1990) used a deterministic-probabilistic analysis of the simulated groundwater-flow system to evaluate what effect uncertainty in model parameters may have on computed hydraulic heads An (1985) and Nork (1987) both studied the various factors that control water-table fluctuations in the valley For a more complete discussion of previous hydrologic investıga- tıons as well as a prelımınary evaluation of the groundwater-flow system of the valley, the reader is directed to Danskın (1988)

Investıgations of water quality have been included as sections in other reports but have not been as prominent as studies of water quantity This lack of attention probably results because both the surface and ground water are generally of good quality A few exceptions exist and these will be addressed in the sections of this report on water quality

EXPLANATION FOR FIGURE 6 - Contınued

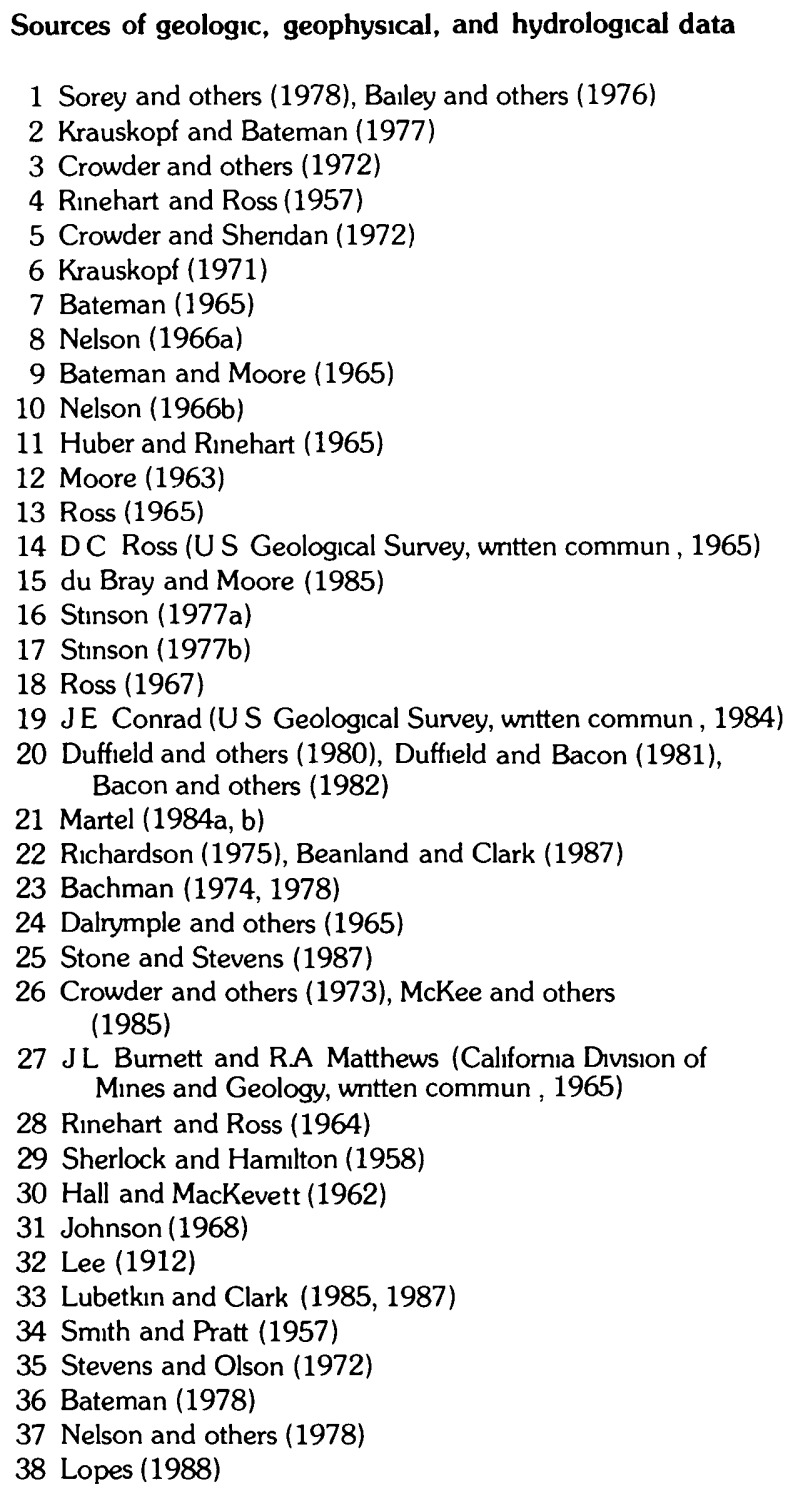

Sources of geologic, geophysical, and hydrological data

1 Sorey and others (1978), Balley and others (1976)

2 Krauskopf and Bateman (1977)

3 Crowder and others (1972)

4 Rinehart and Ross (1957)

5 Crowder and Shendan (1972)

6 Krauskopf (1971)

7 Bateman (1965)

8 Nelson (1966a)

9 Bateman and Moore (1965)

10 Nelson (1966b)

11 Huber and Rinehart (1965)

12 Moore (1963)

13 Ross (1965)

14 DC Ross (US Geologıcal Survey, written commun, 1965)

15 du Bray and Moore (1985)

16 Stınson (1977a)

17 Stinson (1977b)

18 Ross (1967)

19 JE Conrad (U S Geological Survey, written commun, 1984)

20 Duffield and others (1980), Duffield and Bacon (1981), Bacon and others (1982)

21 Martel (1984a, b)

22 Richardson (1975), Beanland and Clark (1987)

23 Bachman $(1974,1978)$

24 Dalrymple and others (1965)

25 Stone and Stevens (1987)

26 Crowder and others (1973), McKee and others (1985)

$27 \mathrm{JL}$ Burnett and RA Matthews (California Division of Mines and Geology, written commun, 1965)

28 Rinehart and Ross (1964)

29 Sherlock and Hamilton (1958)

30 Hall and MacKevett (1962)

31 Johnson (1968)

32 Lee (1912)

33 Lubetkın and Clark $(1985,1987)$

34 Smith and Pratt (1957)

35 Stevens and Olson (1972)

36 Bateman (1978)

37 Nelson and others (1978)

38 Lopes (1988)

\section{Additional information that includes all or a large part of} Owens Valley

Bateman (1961)

Bateman and others (1963)

Bateman and Merram (1954)

Bateman and Wahrhaftıg (1966)

S L Beanland (Univ of New Zealand, written commun, 1986)

Beaty (1963)

Birman (1964)

Blackwelder (1928, 1954)

Blakely and McKee (1985)

Bryant (1984)

California Division of Mines and Geology (1982)

Chapman and others (1973)

Christensen (1966)

Cleveland (1958)

Conklıng (1921)

Conrad and McKee (1985)

Conrad and others (1987)

Dalrymple (1963, 1964a, b)

Evernden and Kustler (1970)

Gale (1915)

Gillespie (1982)

Govannettı (1979a, b)

Gnepentrog and Groeneveld (1981)

Jennings (1975)

Kane and Pakıser (1961)

Knopf (1918)

Langenhe1m and others (1982a, b)

Lee (1906)

Lemmon (1941)

Los Angeles Department of Water and Power $(1972,1976$, 1978, 1979)

McKee and others (1985)

Moore and Dodge (1980)

Nelson (1962)

Oliver and Robbins (1982)

Pakıser and others (1964)

Ross $(1962,1969)$

DB Slemmons and others (University of Nevada, written commun, 1970)

Spurr (1903)

Trowbndge (1911)

US Geological Survey (1983a, b, c)

Van Wormer and Ryall (1980)

Walcott (1897)

Willams $(1966,1969,1970)$

Figure 6. Contınued 


\section{Acknowledgments}

The authors are grateful to many individuals of the Inyo County Water Department and of the Los Angeles Department of Water and Power, who alded immeasurably in all phases of the study Specifically, Melvin L Blevins, John F Mann, Jr , Eugene L Coufel, and Russell H Rawson, representıng the Los Angeles Department of Water and Power, and Gregory L James, William R Hutchison, and Thomas $\mathrm{E}$ Griepentrog, representıng the Inyo County Water Department, were particularly helpful These individuals, and their many associates, supplied logistical and data support, as well as detalled information on the culture, history, and hydrology of the valley Much of this information was based on personal expenence and knowledge gained from many years in the valley The authors also express their appreciation to Fredenck Fisher, U S Soll Conservation Servıce, Sarah Beanland, New Zealand Geological Survey, Allen Gillespie, Unıversity of Washıngton, Lester Lubetkın, U S Forest Service, Craig dePolo, University of Nevada, and Peter Weigand, Robert Howard, and Susan Benham, Calıfornıa State Unıversıty, Northridge, for contributıng geologic information, much of which is in preparation and unpublished In addition, U S Geological Survey colleagues Richard J Blakely, James Conrad, Malcolm M Clark, Donald Ross, and Edwin $\mathrm{H}$ McKee added greatly to our understanding of the geologic and geophysical characteristics of Owens Valley

\section{GEOLOGIC FRAMEWORK AND ITS RELATION TO THE HYDROLOGIC SYSTEM}

The geologic framework-the interrelation of the various sediments and rocks- $1 \mathrm{~s}$ defined by the form and development of the structural valley, as well as its lithology, and by the placement of volcanic rocks and depositional environments of the sediments withın the valley The crystallıne granitıc, metamorphic, volcanıc, and sedımentary rocks surround and underlie the valley

In the Owens Valley drainage basin area, two princ1pal topographic features represent the surface expression of the geologic framework - the mountain ranges, and the long, narrow intermountain valley floor The Sierra Nevada to the west consists primarily of uplifted, faulted, and exhumed batholithic granitic and associated metamorphic rocks These granitic rocks are locally mantled by volcanic rocks and glacial and alluvial deposits (figs 7 and 8) The White and Inyo Mountains to the east consist of tilted and faulted Paleozoic sedimentary rocks that have been intruded by granitic plutons and are mantled in places by volcanic and metamorphic rocks and by Holocene sediments For purposes of this report, the rocks of the Sierra Nevada, White and Inyo Mountains, and Coso Range will be referred to as the "bedrock"
The Volcanic Tableland at the north end of the study area consists of layers of volcanic tuff and ash, many of which were welded during deposition and later vertically faulted The Volcanic Tableland geomorphically separates Round Valley from Chalfant, Hammil, and Benton Valleys, the three northern surface expressions of Owens Valley (fig 1) The welded tuff of the Volcanic Tableland is virtually impermeable and caps valley sediments, thus, for purposes of this report, it is included as part of the bedrock

The valley floor is underlain by thick sequences of unconsolidated to moderately consolidated alluvial fan, transition-zone, glacial and talus, and fluvial and lacustrine deposits intercalated with and overlain by Quaternary volcanic rocks Collectively, the deposits and volcanıc rocks are termed the "valley fill"

The geologic framework determines and controls many hydrologic characteristics of the surface- and ground-waterflow systems Structural deformation, volcanism, and erosion determine the geometry of the mountain ranges as well as the extent and depth of the valley The lithology and structure strongly control the permeability and storage characteristics of the rocks Specifically, these geologic factors can be related to the hydrologic system in the following manner

1 The altitude, surface area, and slope of the mountains are the important physıgraphic factors that determıne the amount of precipitation that will be avallable to the surface-water system or to recharge the ground-water system For closed-basin systems, virtually all streamflow and recharge to the ground-water system result from runoff of rain and snowmelt from the surrounding highlands, in Owens Valley the runoff recharge is predominantly from the Sierra Nevada

2 The quantity of ground water that is stored and flows in the saturated materials is largely a function of the areal extent, thickness, and type of sedimentary deposits that underlie Owens Valley

3 The rocks of the mountains and hills that structurally confine the valley fill may transmit water to the groundwater system through fractures, faults, or solution openings in carbonate rocks The quantity of water from this source, however, is considered insignificant compared to the quantity of water infiltratıng from streams or the quantity of ground-water underflow through the volcanic rocks or sedimentary deposits

\section{Regional Geologic Setting}

The earliest known geologic history in the Owens Valley region is recorded in the rocks of surrounding mountains and has been summarized in numerous references cited in figure 6 and in the geologic column in figure 8 Outcrops of marine sedimentary rocks in the White and Inyo Mountains and mountain ranges to the east (fig 8) support the 
interpretation that this region was on the margin of an ancestral Pacific Ocean continental shelf during the late Precambrian and Paleozoic Era During the middle and late Paleozoic, the marine sediments were folded and faulted by the Antler and Sonoma orogenies (Russel and Nokleberg, 1977, McKee and others, 1982, Langenheim and others, 1982a) Deformation contınued into the Mesozoic with the onset of the Nevadan orogeny and the intrusion of the Sierra Nevada batholith The early Cenozorc Era was a period of both regional uplift and erosion that may account for the absence of rocks of this age in Owens Valley

Basin and Range faultıng, which followed early Cenozoic uplift and erosion in the late Tertiary, produced the present Owens Valley structure Evidence of Basin and Range faultıng in the western part of the Great Basin section has been studied in areas about $60 \mathrm{mi}$ north of Owens Valley in the Carson, Smith, and Mason Valleys (Gilbert and Reynolds, 1973) Other evidence has been found in Death Valley (Schweig, 1986) and in the vicinity of the Nevada Test Site north of Las Vegas (Ekren and others, 1968) Evidence found as a part of these studies indicates two different epısodes of faulting, distinguished by different regional fault orientations An early episode, which occurred during the Miocene and Pliocene, produced northeast- and northwest-trending faults This early episode of faulting is not readily apparent in Owens Valley because it may be concealed by recent volcanic rocks and extensive sediments The northwest-trending faults located near Poverty Hills and in the White and Inyo Mountains (fig 7) may be remnants of this earlier episode of faulting (Cleveland, 1958, Martel, 1984a, b, this study) Bateman (1965), however, attributed some of the northwest-trending faults in the White and Inyo Mountains to pre-Basin and Range faultıng Stud1es by dePolo and dePolo (1987) showed that northwesttrending fault systems are still seismically active in the Bishop area Other indirect evidence of the earlier episode is found in the Coso Formation of late Tertiary age (Schultz, 1937) and the lake deposits of the Waucobi Embayment (Walcott, 1897) which were deposited in basins that were precursors to the present Owens Valley (Bachman, 1978, Bacon and others, 1982) The configuration of these precursory basins is still unknown

The later epısode of Basın and Range faultıng is characterized by north-south-trending normal faults that delineate the edges of the mountain ranges and valleys in the western part of the Great Basin section This later episode occurred about 13 million years ago in Death Valley, $50 \mathrm{mi}$ east of Owens Valley, and gradually migrated westward reachıng Owens Valley between 3 and 6 million years ago (Schwerg, 1986) Radıometric ages of faults that cut volcanic rocks along the Sierra Nevada (Dalrymple, 1964a, b), the dating and correlation of rocks in the Coso Range and southern Inyo Mountains (Giovannettı, 1979a, b, Duffield and others, 1980, Bacon and others, 1982), and the datıng and depositional trend of the Waucobi Lake deposits in the
Waucobı Embayment (Hay, 1964, Bachman, 1974, 1978) (fig 7), all indicate that the north-trending normal faults that form Owens Valley are younger than 6 million years old On the basis of the age of formation, Owens Valley is one of the youngest valleys in the Basin and Range province Recent seismicity and surface disruption along the major faults in the valley demonstrate that Owens Valley is stıll tectonically active (Kahle and others, 1986, Lienkaemper and others, 1987, dePolo, 1988)

Uplift and tiltıng of the Sierra Nevada by Basin and Range faultıng brought increased elevation and subsequent alpine glaciation during the Pleistocene and Holocene to tributaries of the Owens River (Blackwelder, 1931, Sharp and Birman, 1963, Gillespie, 1982) Glacial advances in the Sierra Nevada have been dated at 32 million years (Dalrymple, 1964a, b) to as recent as 400 years ago (Gillespie, 1982) Some Pleistocene glaciers extended to the mountain front, pushing moraines onto the edge of Owens Valley, but neoglacial (late Holocene) activity has been confined to the higher canyon altitudes Periods of glaciation have produced abundant glacial deposits The largest accumulations of glacial deposits in the Owens River drainage basin are located in the canyons west of Big Pine and Bishop (fig 7) Streams have breached the Pleistocene moraines, and debris ranging in size from boulders to glacial flour is transported into Owens Valley, where it forms part of the valley fill

Contemporaneous with Basın and Range faultıng, glaciation, and the development of the graben that underlies Owens Valley was the deposition of Quaternary and Tertiary sediments and volcanic material during the past 6 million years Owens Valley is the present terminus for the Owens River drainage basin area and final depository of sediments eroded from the surrounding highlands During the pluvial stages of the Pleistocene, Owens Valley was integrated into a more extensive Owens River drainage system This Pleistocene drainage system included at various times, Mono, Adobe, Long, Indian Wells, Searles, Panamint, and Death Valleys-which now lie adjacent to and north, east, and south of Owens Valley (G E Barley, 1902, Gale, 1915, Meinzer, 1922, Blackwelder, 1931, 1954, Mayo, 1934, Miller, 1946, Hubbs and Miller, 1948, Putnam, 1950, Feth, 1964, Snyder and others, 1964, Williams and Bedinger, 1984, Jannik and others, 1987) Owens Valley, located at the base of many glaciers in the Sierra Nevada, was a sed1ment trap for the Pleistocene Owens River drainage basın area The present Owens Lake is a remnant of the more extensive Pleistocene Lake Owens, which occupıed Owens Valley during pluvial stages Downstream from Lake Owens, in the Pleistocene drainage system, lakes in Indian Wells, Searles, and Death Valleys received the overflow from Owens Valley (Gale, 1915, Jannik and others, 1987) Smith (1979) and Smith and others (1983) correlated the pluvial stages of Lake Searles with the Sierra Nevada glacial stages Although Lake Searles completely dried at tımes, the dryıng 


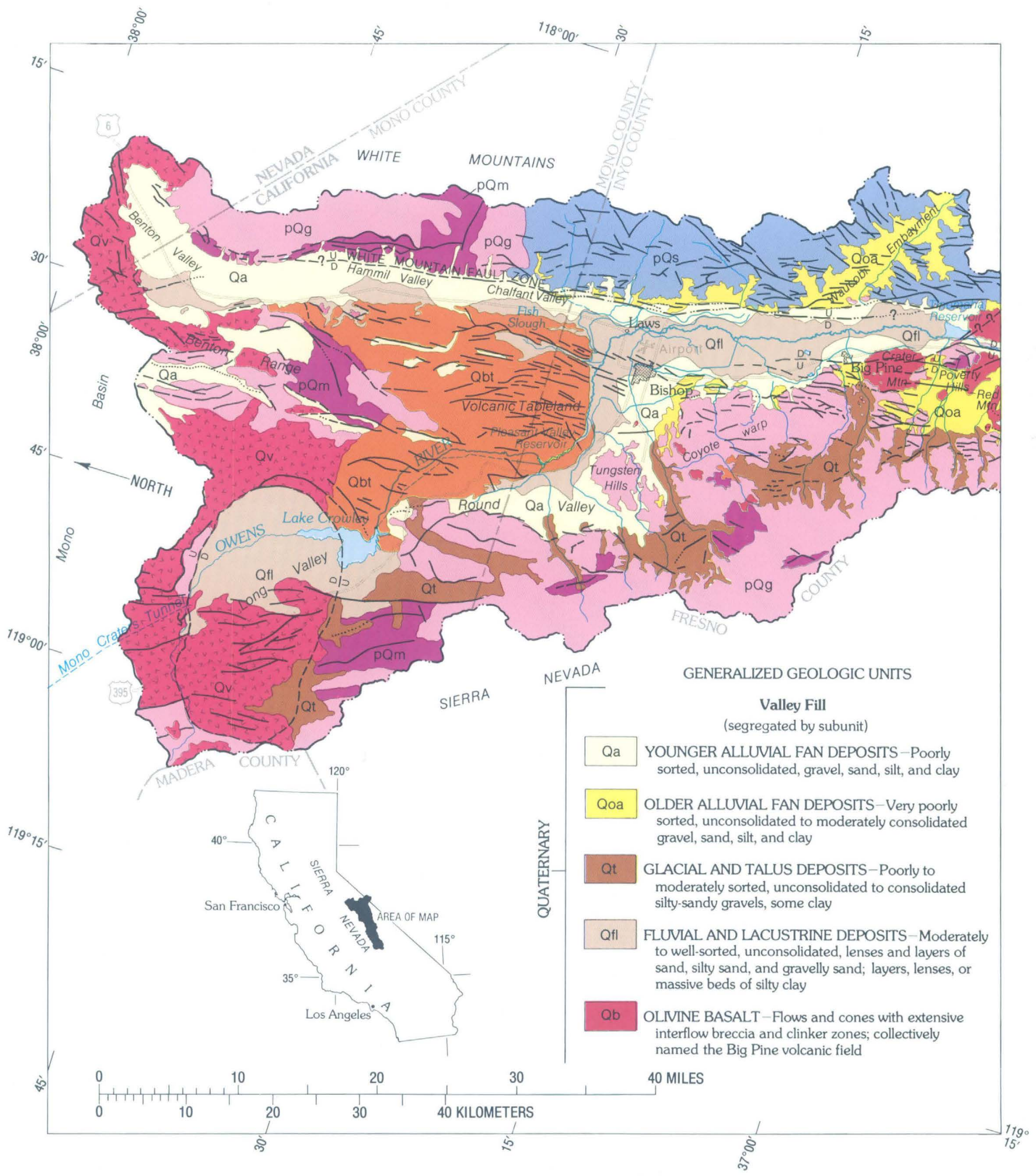

Figure 7. Generalized geologic map of the Owens Valley drainage basin (geology compiled from sources shown in fig. 6 and this study). 


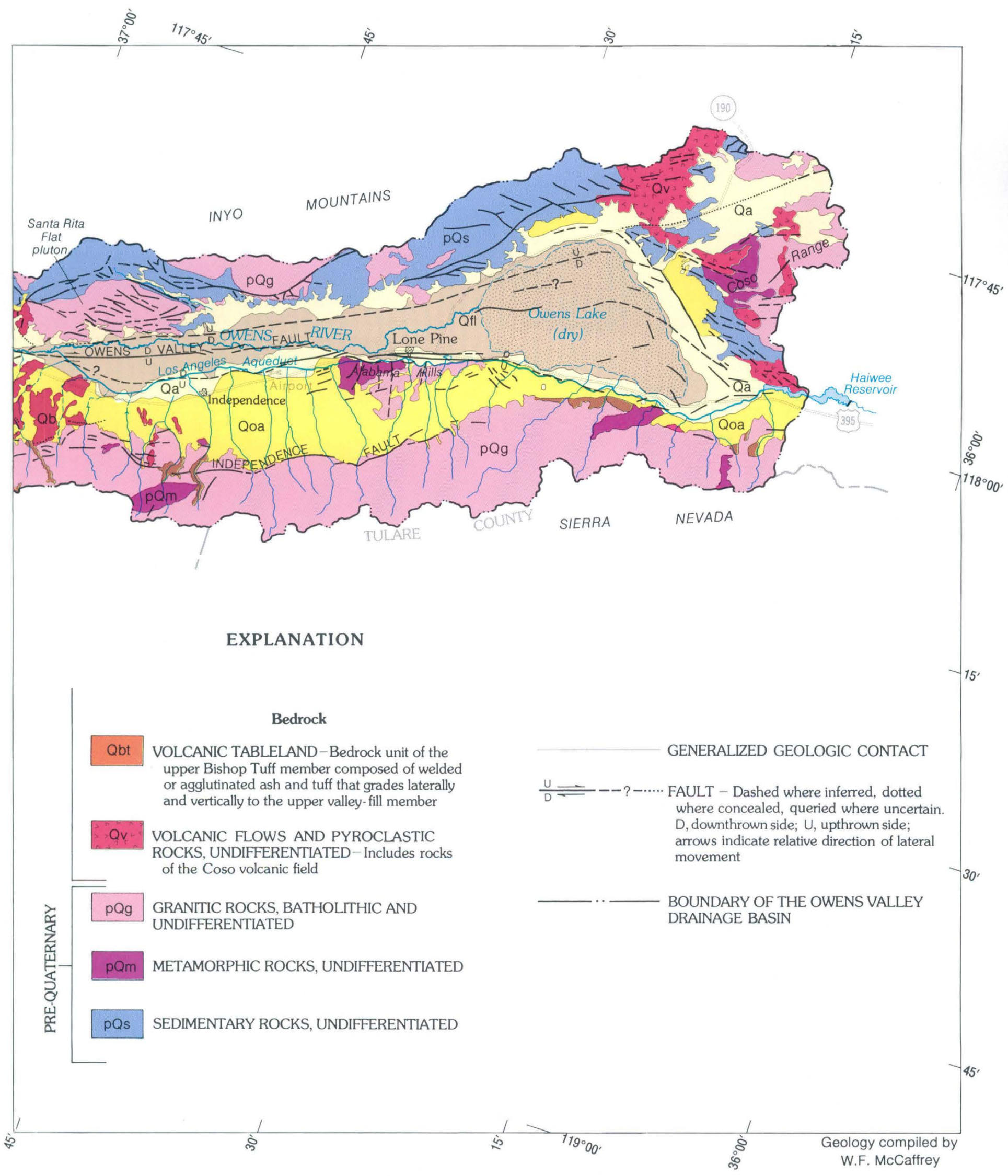

Figure 7. Continued. 
of Lake Owens during the middle through late Pleistocene is considered unlikely owing to the absence of any evaporites in a 920-foot-long core from the Owens Lake playa (Smith and Pratt, 1957). The water level in Lake Owens probably fluctuated numerous times, as indicated by the variation in overflow to Lake Searles (Jannik and others, 1987) and from the location of lake margin sediments in the vertical geologic record in the valley.

The water-level fluctuations in Lake Owens caused broad shifts in the depositional environment across the gentle slope of the valley floor. W.T. Lee (1906) suggested that Lake Owens once extended as far north as Bishop.
Pleistocene beach terrace levels from Lake Owens, however, do not support W.T. Lee's (1906) single-lake hypothesis. The altitude of terrace levels has been mapped at 3,790 ft (C.H. Lee, 1912); 3,790 and 3,800 ft (Knopf, 1918); 3,753 $\mathrm{ft}$ (Lubetkin and Clark, 1985); and 3,860 ft above sea level (S.L. Beanland, New Zealand Geological Survey, oral commun., 1985). A geologic reconstruction of the alluvial fan surface at Haiwee Reservoir is about $3,865 \mathrm{ft}$ above sea level prior to downcutting of the gorge by the Pleistocene Owens River. The surface altitude of this alluvial fan agrees well with beach terrace levels measured by S.L. Beanland (University of New Zealand, oral commun., 1985) and may

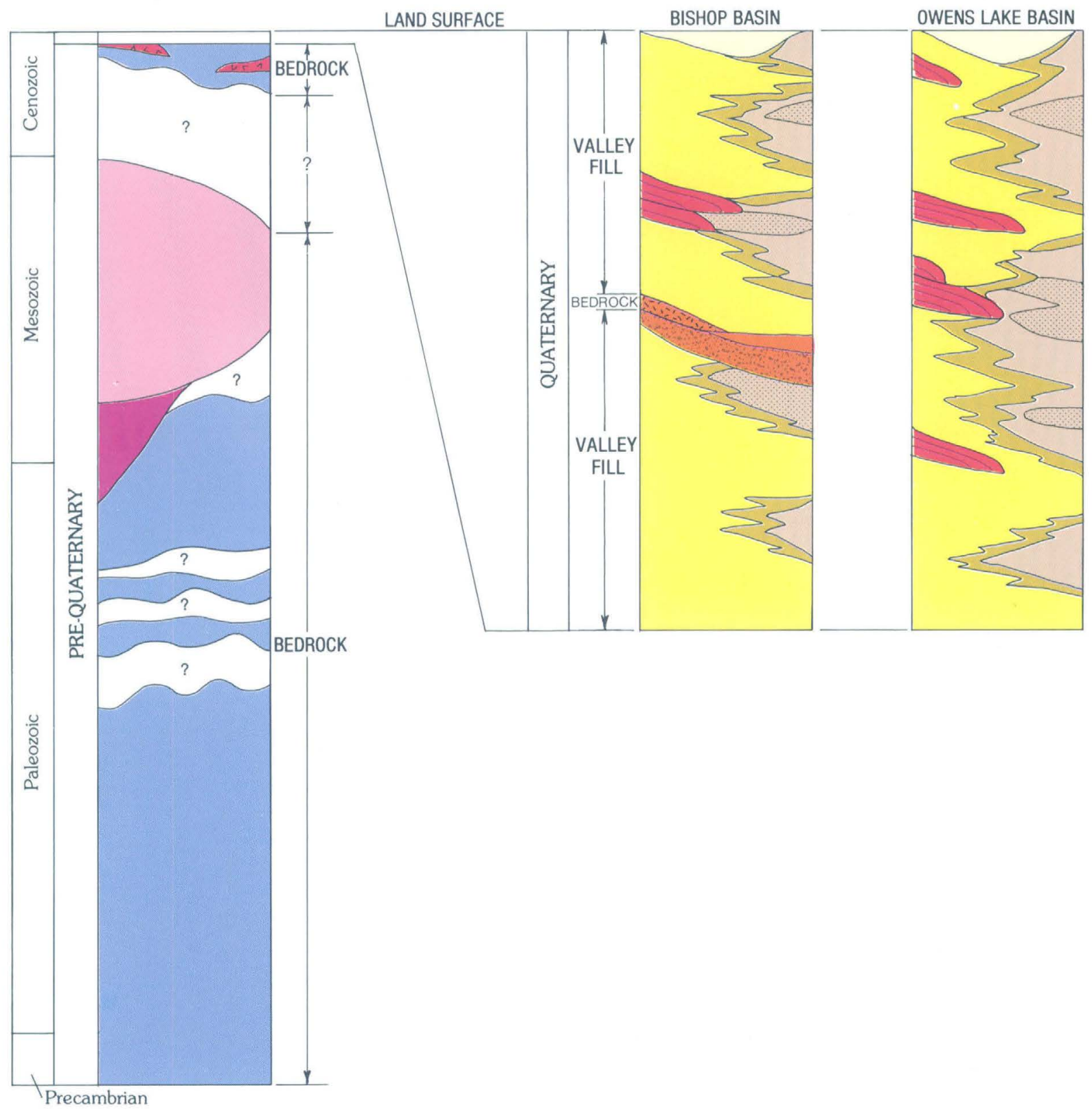

Figure 8. Generalized geologic column and hydrologic characteristics of the valley fill and bedrock units within the Bishop and Owens Lake Basins (see fig. 11) of the Owens Valley drainage basin area. 
represent the highest level of Lake Owens that was present in the valley before spilling and downcutting of the gorge at Haiwee Reservoir. The lowest natural outlet of Pleistocene Lake Owens or the present Owens Lake is controlled by the altitude of the base of the Owens River in the gorge at Haiwee Reservoir. Prior to construction of the reservoir, topographic surveys of the gorge measured the highest base of the river in the gorge at 3,755 $\mathrm{ft}$ above sea level (Los

\section{EXPLANATION \\ QUATERNARY VALLEY FILL \\ (Segregated by subunit)}

YOUNGER ALLUVIAL FAN DEPOSITS - Poorly sorted clays and sands, some pebbles and cobbles. Generally low storage and low hydraulic conductivity

OLDER ALLUVIAL FAN DEPOSITS-Very poorly sorted, consisting of clays to boulders in discontinuous lenses. Parts are moderately consolidated. Low storage and hydraulic conductivity

FLUVIAL AND LACUSTRINE DEPOSITS-SILT AND CLAY BEDS AND LENSES-Lacustrine and flood-plain deposits. Extensive lacustrine and flood-plain deposits along the axis of the valley. Undifferentiated. Lenses are discontinuous, but a series of overlapping lenses act as a single bed of low conductivity

FLUVIAL AND LACUSTRINE DEPOSITS-MODERATELY TO WELL-SORTED SANDS - Lacustrine and river-channel origin. Generally moderate to low storage and hydraulic conductivities, depending on the amount of clay or silt present

OLIVINE BASALT - Includes flows and cones with clinker zones, flow breccia, and pyroclastic beds. Flows interbed with valley-fill deposits. Very anisotropic, low storage, and very high hydraulic conductivity. High secondary permeability caused by fractures and joints

TRANSITION - ZONE DEPOSITS-GRAVELS OF BEACHES AND RIVER CHANNELS-Moderately to well sorted, forming lenses and stringers. Beach deposits originate within the transition area between alluvial fan deposition and fluvial-lacustrine deposition where alluvial deposits have been reworked and are moderately to well sorted. Deposits within this zone generally have moderate to high storage and hydraulic conductivities

BISHOP TUFF-Upper member composed of friable ash, pumice, and tuff. Moderate storage and hydraulic conductivity

BISHOP TUFF - Lower basal member composed of pumice, generally high storage and hydraulic conductivity

\section{QUATERNARY BEDROCK}

VOLCANIC TABLELAND - Part of upper member of the Bishop Tuff and composed of welded or agglutinated ash and tuff. Low storage and hydraulic conductivity except where jointed or faulted, which creates moderate to high secondary permeability

\section{PRE-QUATERNARY BEDROCK}

VOLCANIC ROCKS, UNDIFFERENTIATED - Composed of basalt, rhyolite, and volcanic rocks of intermediate composition

GRANITIC ROCKS, UNDIFFERENTIATED -Varying in composition from granite to diorite

METAVOLCANICS AND METASEDIMENTARY ROCKS, UNDIFFERENTIATED-Metamorphic rocks derived from other bedrock deposits

SEDIMENTARY ROCKS, UNDIFFERENTIATED-Composed of limestones, dolomites, and shales. Sandstones and conglomerates locally contact metamorphosed

Figure 8. Continued. 
Angeles [city of] Board of Public Service Commissioners, 1916, pl 11) The altitude of the natural outlets of Lake Owens and Owens Lake probably ranged between 3,755 to $3,865 \mathrm{ft}$ above sea level But even at the highest level, the lake did not extend north of Poverty Hills and into the north half of the valley, which are at higher altitudes Minor fluctuations of water level below the altitude of the outlet as indicated by water-level fluctuations recorded in Searles Lake (Smith and others, 1983) would cause broad northsouth shifts in the depositional environment across the valley floor at the north end of Lake Owens

\section{Structure of Owens Valley}

Owens Valley is a downdropped block of bedrock (graben) that is bounded on the west and east by steep mountain blocks (horsts) of virtually impermeable bedrock (fig 9) These bedrock blocks were faulted, tilted, rotated, and warped, then sculptured by erosion and partly buried by sediments and volcanic rocks This type of structural valley form is typical of the Basin and Range province Various models of Basin and Range structural form and evolution have been presented by Gilbert (1938), Nolan (1943), Roberts (1968), Stewart (1971, 1978), Anderson and others (1983), and Allmendinger and others (1987) The generally accepted models of Basın and Range formation involve a series of structurally complex grabens (basins or valleys) separated by horsts (mountain blocks), together which create a linear arrangement of valleys or basins and mountain ranges The structure of Owens Valley strongly affects ground-water storage and flow

The shape of the graben beneath Owens Valley (fig 9) has been inferred primarily from geophysical studies (Pakıser, 1960, Kane and Pakıser, 1961, Pakıser and others, 1964, Blakely and McKee, 1985, this study) Gravity, seismic refraction, aeromagnetic, and vertical electric surveys are the principal geophysical methods that have been used to define the form and depth of the buned bedrock surface, the extent and distribution of major normal faults, and concealed unconsolidated sediments Pakıser and others (1964) used gravity and seismic refraction methods to do an extensive analysis of the regional structure of the valley Their analysis served as the background for this study Recent geophysical studies by Blakely and McKee (1985) expanded the geophysical data base of Pakıser and others (1964) by adding more than 400 new gravity stations in the White and Inyo Mountains, editıng the combined data set, and adjusting the data to a common gravity base This data set also was adjusted for the regional gravity field by using an Airy isostatic model (Simpson and others, 1983) to produce an isostatic residual gravity anomaly for each station More than 6,700 points from this data set (R J Blakely, U S Geological Survey, written commun, 1985) were gnidded and contoured (fig 10), and selected profiles modeled two-dimensionally, for the structural analysis in this study
The use of a contoured spatial distribution of isostatic residual gravity anomalies enables the investigator to 1solate density inhomogeneities and contrasts created by less dense valley fill in contact with more dense bedrock When contoured, the anomalies give a three-dimensional approximation of the bedrock surface Typically, complete Bouguer residual gravity maps have been used to model the depth of bedrock However, because of the extreme topographic relief in some mountainous areas, such as the area surrounding Owens Valley, smaller gravity anomalies that represent subtle geologic changes in the near surface can be masked by long-period anomalies that arise from isostatic compensation of topography (Jachens and Griscom, 1986) Isostat1cally compensated gravity anomaly data were used in this study to better understand the geologic structure and depth to bedrock in Owens Valley

The isostatic residual gravity anomaly map of the Owens Valley drainage basin area reflects the general shape of the structural valley as well as the orientation of many of the major faults (fig 10) The faults that are shown overlaid on the gravity map coincide with steep gradients of horizontal change in gravity in the zone between the more dense bedrock of the mountains and the less dense valley fill Hachures on closed contours indicate the direction of lowest gravity Generally the deepest parts of the basin are identified by the lowest, closed gravity lines and are bounded by steep normal faults that delineate the side of the valley graben The inferred position of the lowest parts of the graben are illustrated by bold lines (fig 10) The intense low shown in the northwest part of the drainage basin area represents the Long Valley caldera (fig 10)

The Poverty Hills, located just south of Big Pine (figs 1,7 , and 10), were interpreted by Pakiser and others (1964) as a gravity slide block resting atop valley-fill sediments The slide block interpretation may allow for a potentially significant quantity of ground water to move through the valley-fill sediments beneath the structure Martel (1984a, b) reinterpreted the structure of Poverty Hills as a bedrock horst uplıfted by differentıal, left-lateral, strıke-slıp movement of the Owens Valley fault (figs 7 and 10) This reinterpretation suggests a bedrock core beneath Poverty Hills-an interpretation that is supported by the geologic and geophysical interpretations of this study The virtually impermeable bedrock horst of Poverty Hills acts as a barrier that diverts ground-water flow around the hills

The Alabama Hills, located west of Lone Pine (figs 1,7 , and 10), also represent an erosional remnant of the granitic bedrock and are a part of the Sierra Nevada batholith Previous investigators (Pakiser and others, 1964, Richardson, 1975) postulated that the north end of the hills was truncated by a west-trending normal fault, with the north side down Beanland and Clark (1987), when mapping Quaternary faults near the Alabama Hills, observed no evidence of a major fault at the north end of the hills Gravity data (fig 10 ) support the interpretation of Beanland 
and Clark and further suggest that the Alabama Hills extend northward in the subsurface as a bedrock block, east side down (figs. 7, 9, and 10). The east margin of this block can be traced as a nearly continuous series of normal faults (east side down), north to the Poverty Hills (figs. 7 and 10 and pl. 1). The east margin of the buried bedrock block is coincident with a few springs and lineaments that may represent older surface ruptures found between the Alabama Hills and Independence.

The graben that underlies Owens Valley can be divided into two structural basins (fig. 11) - Bishop Basin and Owens Lake Basin - on the basis of geophysical and structural information. The extent and orientation of each basin is defined by the deepest part of the graben (fig. 10) and the major faults that offset bedrock blocks to form the graben (figs. 7 and 10 and pl. 1). Bishop Basin is displaced east relative to Owens Lake Basin (fig. 11).

\section{Bishop Basin}

Bishop Basin is bounded on the east by the White Mountain fault and on the west by the Coyote warp section of the Sierra Nevada (fig. 7). The warp is a broad flexural surface resulting from a distributive system of faults along the eastern Sierra Nevada north of Big Pine (Knopf, 1918; Pakiser and others, 1964; Bateman, 1965). The warp extends beneath the valley fill toward Bishop (Pakiser and others, 1964). A discontinuous series of faults in the unconsolidated valley-fill sediments extends along the east flank of the warp toward Fish Slough (fig. 7; Bryant, 1984; this study). This discontinuous trend of fault segments may be the result of a deeper buried fault zone. North of the Poverty Hills (Martel, 1984a, b) the Owens Valley fault (fig. 7) steps to the west and is located along the west margin of the valley, where it is concealed by the valley fill east of the Coyote warp and north of Big Pine.

Pakiser and others (1964) inferred that the northern limit of the Owens Valley graben (Bishop Basin of this study) is buried beneath the Bishop Tuff, the nearly horizontal layers of tuff and ash that make up the Volcanic Tableland. This inference is supported by recent geophysical and geologic information (figs. 7, 10, and 11). Bishop Basin and Long Valley do not appear to be connected by a relict valley beneath the Volcanic Tableland as postulated by the California Department of Water Resources (1960). Instead, Long Valley and Bishop Basin are separated by a granitic ridge that trends

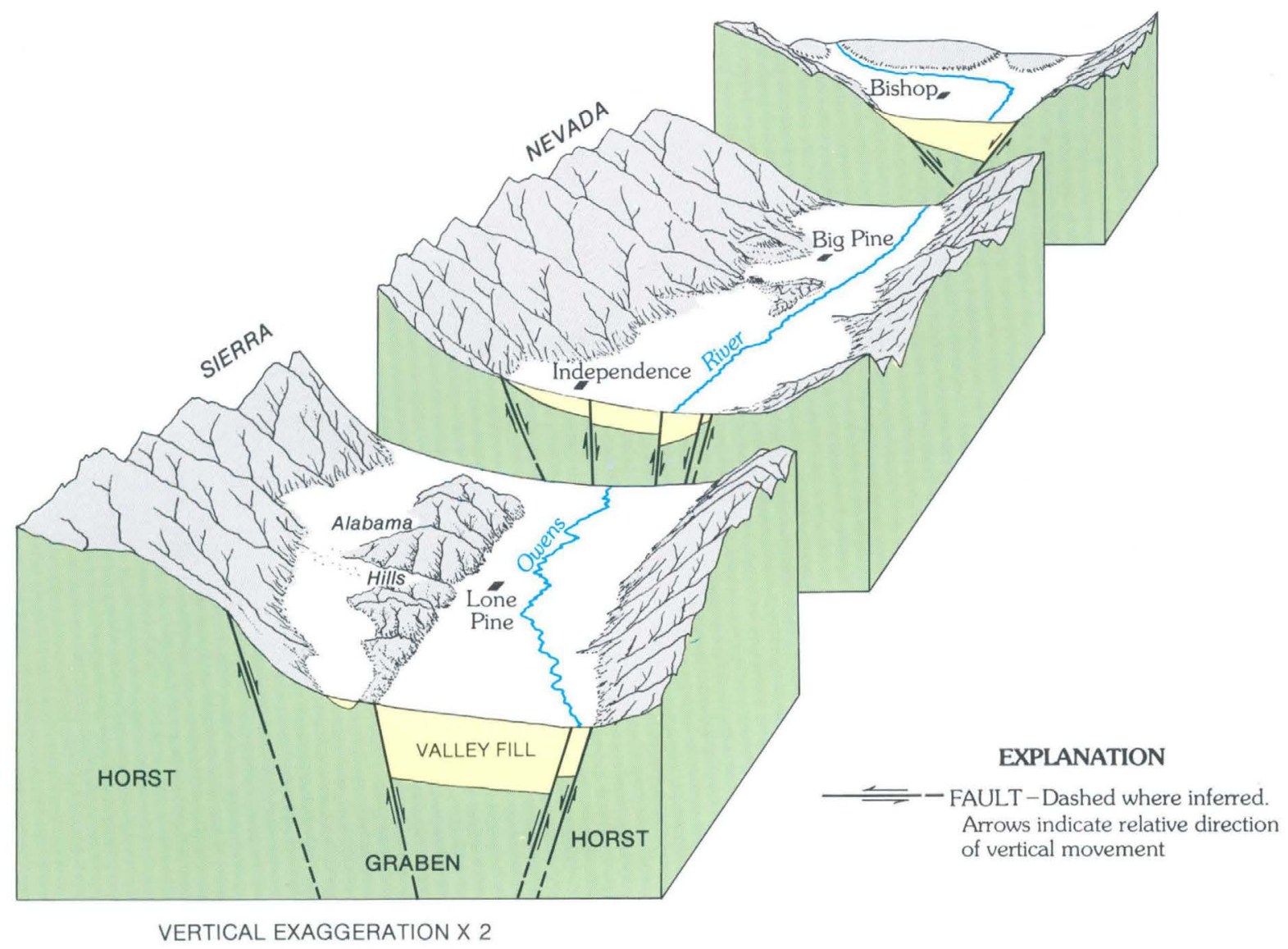

Figure 9. Schematic block diagram of Owens Valley that illustrates the structural relation between the mountain blocks (horsts) and the valley trough (graben). 


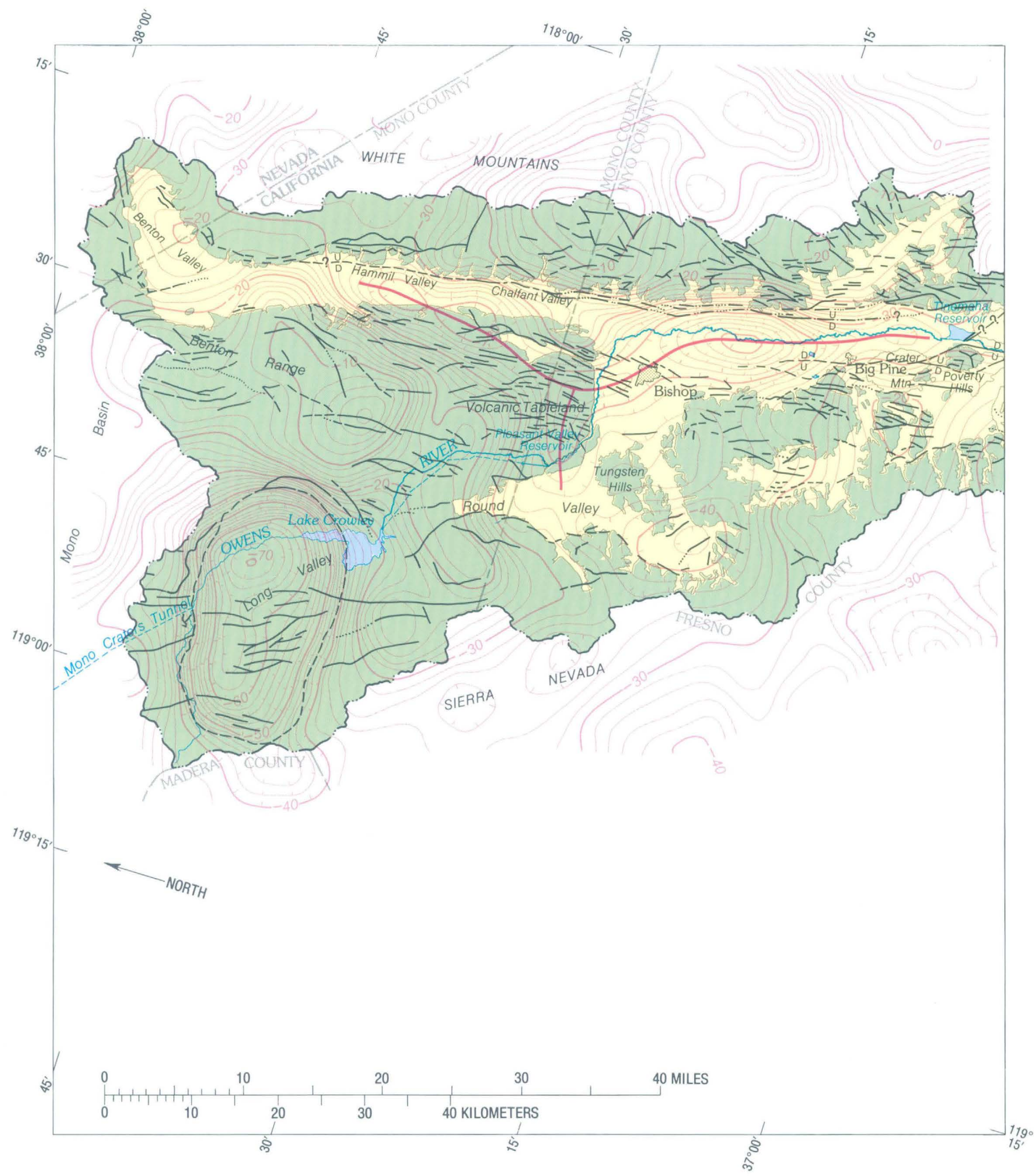

Figure 10. Isostatic residual gravity anomalies, geologic structure, and inferred position of the structurally lowest part of the Owens Valley graben. 


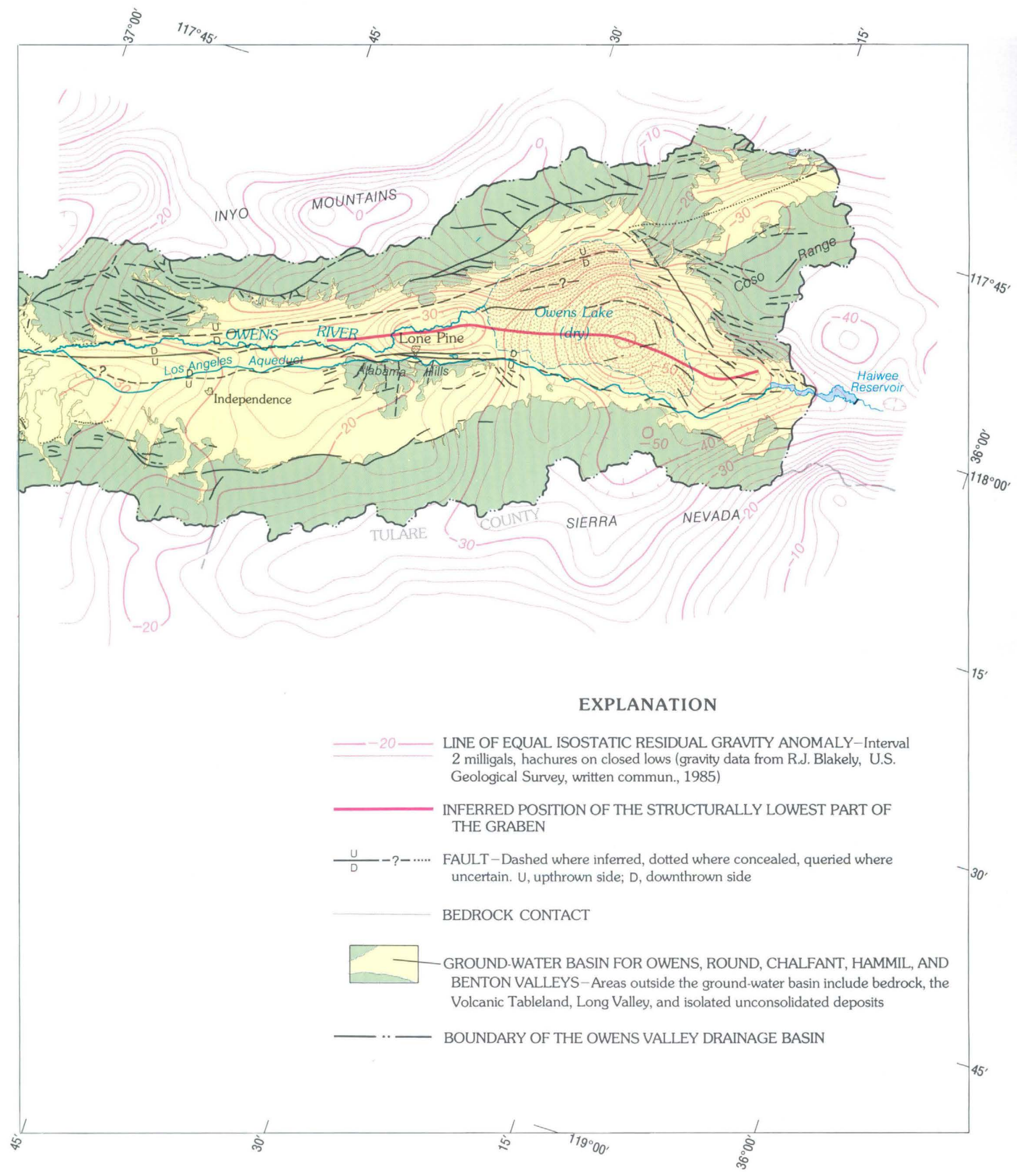

Figure 10. Continued. 


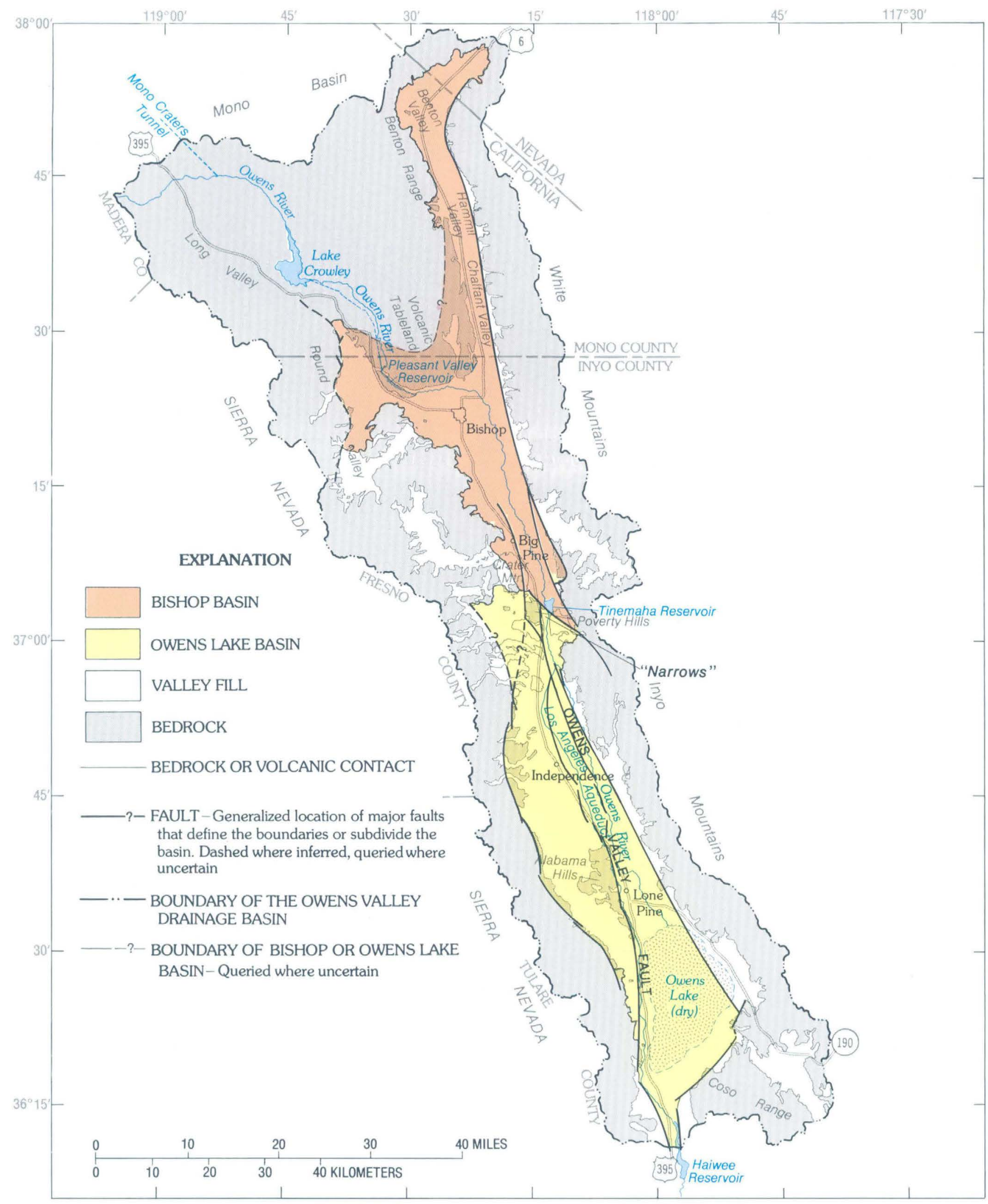

Figure 11. Structural division of Owens Valley into Bishop and Owens Lake Basins, hydrologically connected through the geomorphic "narrows" east of and adjacent to Poverty Hills. 
northeast to southwest from the south end of the Benton Range to the Sierra Nevada (unit pQg, fig 7) This ndge is exposed in the Owens River gorge that cuts the Volcanic Tableland between Lake Crowley and the Bishop area Near the bottom of the gorge, granitic rocks are directly overlain by basalt and tuff East of the exposure, the ndge is buried beneath the Volcanic Tableland The position of the ndge where buried has been delineated by the abrupt change in the gravity gradient (fig 10)

Beneath the Volcanic Tableland, Bishop Basin bifurcates along the buried granitic nidge to form Round Valley to the west and Chalfant, Hammil, and Benton Valleys to the east A zone of north- to northeast-trending discontinuous faults along Fish Slough north of Bishop (figs 1 and 7) mark the east side of the subsurface extension of Chalfant, Hammil, and Benton Valleys, which is buried beneath the Volcanic Tableland (fig 7) Farther east the valleys are bounded by the White Mountains along the White Mountain fault (fig 7) Round Valley is bounded on the north, west, and south by granitic rocks of the Sierra Nevada batholith

The southern limit of Bishop Basin is marked by an inferred normal fault that crosses the valley in a northwestsoutheast direction across the north side of Poverty Hills (Cleveland, 1958, C M dePolo, University of Nevada, written commun, 1986, this study, figs 7, 10, and 11) The bedrock offset along this fault is north side down and is concealed by recent sediments and interstratified basalt flows of the Big Pine volcanic field This normal fault is a part of the southern structural terminus of the Bishop Basin, which forms a bedrock high between the Bishop Basin and the Owens Lake Basin to the south

The bedrock high, adjacent and to the east of Poverty Hills, virtually isolated the depositional system of the Bishop Basin from that of the Owens Lake Basin during much of the time Owens Valley was being filled with sedıments Graben subsidence was contemporaneous with fluvial and shallow lake deposition in both basins untıl middle-to-late stages of valley formation When deposition exceeded graben subsidence, the bedrock high or ridge was buried and the two basins acted as one Following burial of the ridge, interbasin fluvial deposition contınued untıl interrupted by the Big Pine volcanic episode This volcanic episode extruded surface flows, cinder cones, and dikes of basalt, presumably along the cross-cutting faults in the Poverty Hills area These volcanic extrusions interrupted the surface drainage between basins and formed a lake or series of lakes in Bishop Basin

The numerous epısodes of lacustrine sedimentation in the southern part of the Bishop Basin have formed extensive layers of clay in the stratigraphic sequence of the valley fill Some layers, such as the blue and green clay located in the southern part of the Bishop Basin, are laterally extensive (fig 12) The lower blue clay is in contact with the green clay, and together they form a single layer of bluegreen clay (as they will be referred to subsequently in this report) The blue-green clay, for example, extends and thins from the "narrows" to about Big Pine (figs 11 and 12) The blue-green clay is not found in the sediments south of the "narrows" The basalt flows that formed a dam to downvalley streamflow at the "narrows" were probably later breached by the ancient Owens River Alternatıng beds of lacustrine clay and fluvial sands and gravels in the stratigraphic sequence at the "narrows" (fig 12) suggest that the process of blockage and breaching may have occurred several times The surface and near-surface fluvial sediments at the "narrows," just prior to construction of Tinemaha Reservoir, reflect a breached condition and indicate that the hydraulic connection between the Bishop and Owens Lake Basins has been present during recent tıme Less than 1,500 $\mathrm{ft}$ of valley fill underlies the "narrows," Including intercalated volcanic flows (pl 1, section $H-H^{\prime}$ ) This thickness contrasts markedly with the more than $4,000 \mathrm{ft}$ of valley fill found in the deepest part of Bishop Basin north of Big Pine The deepest part of Bishop Basin is indicated by the pronounced gravity low in figure 10

The northern extension of the valley graben under Chalfant, Hammıl, and Benton Valleys is partly isolated from the deepest part of Bishop Basın by a bedrock slump block A high, isolated gravity anomaly depicted in the contoured gravity northeast of Bishop and west of the White Mountain fault zone defines the extent of the buried slump block of the bedrock that partially obstructs the south end of the Chalfant Valley (fig 10) The isolated gravity high was first recognized by Pakıser and others (1964) and postulated as a slump block by Bateman (1965) Recent vertical electric sounding data seem to support the theory of a slump block and indicate that the top surface of the block is about $1,200-1,400 \mathrm{ft}$ below land surface A pronounced alluvial fan has formed westward across the slump block The protrusion of the buried slump block at the south end of Chalfant Valley, conjunctive with the overlying fan, probably deflects deep ground waterflowing south along Chalfant, Hammil, and Benton Valleys to the Bishop Basin-farther west beneath the southeastern part of the Volcanic Tableland near Fish Slough This is west of where underflow would be expected on the basis of present topography

\section{Owens Lake Basin}

Owens Lake Basın extends from the "narrows" near Poverty Hills south to the Coso Range (fig 11) The east margin of the basin is delineated by a fault zone that consists of a 2-mile-wide belt of west-side-down normal faults present along the Inyo Mountains The fault zone is described more fully by Langenheım and others (1982a, b) The west side of the basin is bounded by a fault zone that trends north-south along the east side of the Sierra Nevada This fault zone, partly described by Pakıser and others (1964), is a complex system of faults and downdropped blocks wedged between the Sierra Nevada escarpment and 

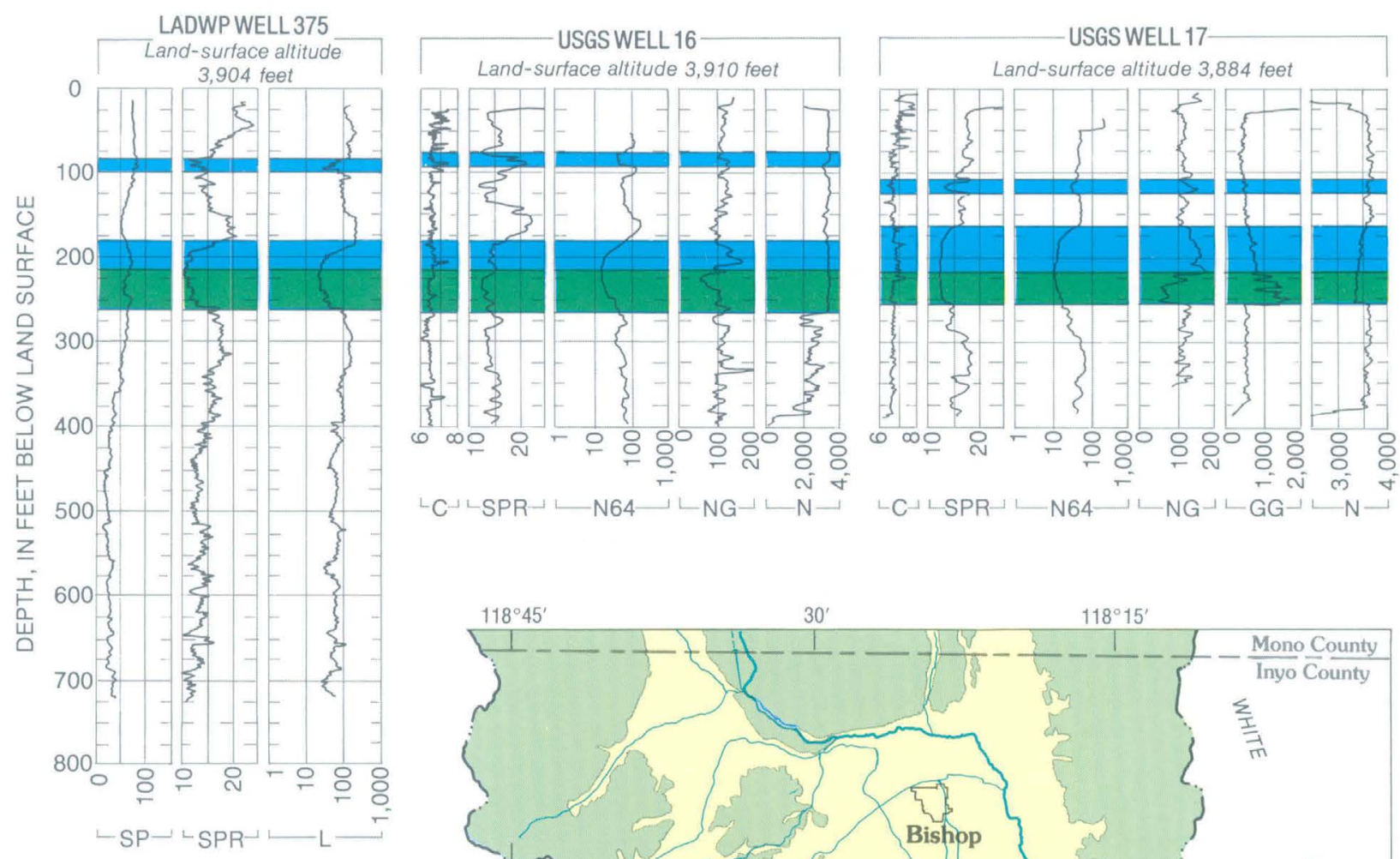

\section{EXPLANATION}

\begin{tabular}{cl}
\hline & VALLEY FILL \\
& BEDROCK \\
& TYPES OF GEOPHYSICAL LOGS \\
SP & Spontaneous potential, in volts \\
SPR & Single point resistance, in ohms \\
C & Caliper, in inches \\
L & 6-foot lateral resistivity, in ohm-meters \\
N64 & 64-inch normal resistivity, in ohm-meters \\
NG & Natural gamma, in counts per second \\
GG & Gamma-gamma, in counts per second \\
N & Neutron, in counts per second \\
& CLAY UNITS-Part of the fluvial and \\
& lacustrine deposits in figures 7 and 8
\end{tabular}

Blue clay Blue-green clay

WELL AND SITE NUMBER -

-16 U.S. Geological Survey (USGS) well and site number

O375 Los Angeles Department of Water and Power (LADWP) well and site number

\section{BOUNDARY OF THE OWENS VALLEY DRAINAGE BASIN}

Figure 12. Borehole geophysical logs of three wells in Bishop Basin and the geophysical correlation of major clay layers in the southern part of Bishop Basin. 
the Owens Valley fault (figs 7 and 11) The Sierra Nevada escarpment has normal east-side-down displacement with no appreciable strike-slip movement (Gillespıe, 1982)

North of the Alabama Hills, the Owens Valley fault is in close proximity to the axis of the valley (fig 7) and effectıvely divides the northern part of the Owens Lake Basin into east and west ground-water-flow systems The Owens Valley fault forms the west side of the valley graben (figs 7 and 9 and pl 1, section $E-E^{\prime}$ ) West of the Owens Valley fault, the bedrock rises in a series of blocks before being exposed in the Sierra Nevada (fig 9) Displacement on the Owens Valley fault is right lateral coupled with minor east-side-down normal movement (Bateman, 1961, Ross, 1962, Lubetkın, 1980, Martel, 1984a, b, Lubetkın and Clark, 1985, 1987, Beanland and Clark, 1987) Pakıser and others (1964) interpreted the Owens Valley fault as a left-lateral strike-slıp fault More current studies (Lubetkın and Clark, 1985, Beanland and Clark, 1987) demonstrated that late Quaternary movement along the Owens Valley fault has been dominantly right lateral with lesser amounts of normal displacement occurring near the Alabama Hills Right-lateral strike slip along the Owens Valley fault is consistent with relative movement determined for faults in valleys to the east of Owens Valley (Stewart, 1967, Wright and Troxel, 1967, Casteel, 1986)

The deepest, widest part of the valley graben underlies the Owens Lake (dry) Between the Alabama Hills and the fault zone along the west margin of the Inyo Mountains, the bedrock floor of the graben dips to more than $8,000 \mathrm{ft}$ below the dry lakebed (figs 7, 9, and 10) To the north, the sides of the graben converge, and the width of the graben diminishes almost to extınction in the "narrows" near the Poverty Hills The floor of the graben rises south to north to less than 1,500 $\mathrm{ft}$ below land surface in the "narrows"

\section{Hydrologic Characteristics of Geologic Units}

The pre-Quaternary bedrock, which consists of granitic, metamorphic, and sedımentary rocks that surround and underlie Owens Valley, has significantly smaller quantities of water than the more porous and hydraulically conductive valley fill Where fractures or dissolution of bedrock matenal are present, some water can be stored or transmitted, but this source of water is difficult to locate and develop and would likely yield minımal quantities of water to wells Because the geologic units of the bedrock do not store or transmit large quantities of water, they form the structural boundary of the groundwater-flow system

Quaternary volcanic rocks constitute a unique geologic unit in the valley (figs 7 and 8) These volcanic rocks can be considered a part of the valley fill or the bedrock, depending on their hydraulic characteristics, their hydraulic connection to the saturated valley fill, or stratigraphic relation to either the valley fill or the bedrock Although generally classified as crystallıne rocks, volcanic rocks commonly contain extensive interflow brecciation, fractures, and lava tubes that can transmit large volumes of water to wells (Wood and Fernandez, 1988) There are three sequences of Quaternary volcanic rocks in Owens Valley the Pleistocene Bishop Tuff, olivine basalts of the Big Pine volcanic field, and the Coso volcanic field (Pakıser and others, 1964) Volcanic rocks in the Big Pine volcanic field and the buried parts of the Bishop Tuff in the Bishop Basin are included with the valley fill (fig 7) The volcanic rocks of the Coso Range volcanic field and the exposed part of the Bishop Tuff that makes up the Volcanic Tableland are included with the bedrock (fig 7)

The Quaternary valley fill consists of the sedımentary deposits and volcanic rocks that fill the valley between the bedrock mountains and hills, cover the lower mountain slopes, and fill the mountain valleys and canyons Sedimentary deposits make up the largest part of the valley fill They range in thickness from a few feet on the margins of the valley, to nearly $1,500 \mathrm{ft}$ in the "narrows," to more than $4,000 \mathrm{ft}$ in the depositional center of the Bishop Basin, and to more than $8,000 \mathrm{ft}$ beneath Owens Lake (dry) The valley fill is subdivided on the basis of mode of deposition The following descriptions of the bedrock, the volcanic rocks, and the valley fill emphasize their hydrologic characteristics

\section{Bedrock}

The bedrock of Owens Valley consists of pre-Quaternary granitic, metamorphic, sedimentary, and to a lesser extent, pre-Quaternary and Quaternary volcanic rocks The combined granitic and metamorphic rock assemblage is referred to as crystalline bedrock Granitic plutons of the Sierra Nevada batholith form the core of the Sierra Nevada and Coso Range (Moore, 1963, Bateman and others, 1963, Rinehart and Ross, 1964, Bateman, 1965, Bateman and Wahrhaftig, 1966, Duffield and others, 1980, Duffield and Bacon, 1981) Additionally, plutons of the Sierra Nevada batholith underlie large areas of the White and Inyo Mountains (Knopf, 1918, Nelson, 1966a, b, Crowder and others, 1972, 1973, Crowder and Sheridan, 1972, Sylvester and others, 1978, Blakely and McKee, 1985, McKee and others, 1985) The plutons vary in composition from gabbro to quartz monzonite, with quartz dionte makıng up the bulk of plutonic rock Correlation of the plutons across Owens Valley (Ross, 1962) implies that the granitic rock is contınuous across the valley beneath the valley fill

A regional system of conjugate joints is present in most granitic rocks of the Sierra Nevada (Bateman, 1965) The joints trend either northwest or northeast and are most conspicuous in areas of low relief because of a greater rate of weathering along fractures Ross (1969) recorded a similar pattern in the Santa Rita Flat pluton, located about $5 \mathrm{ml}$ east of Poverty Hills in the Inyo Mountains (fig 7) The granitıc rocks of the Sierra Nevada batholith have low porosity and hydraulıc conductivity, except along fractures and joint inter- 
sections where weathered rock and alluvial deposits are present Locally, fractures are interconnected hydraulically in the granitic rocks and thus provide a means for some water production from wells and for small quantities of recharge to the valley fill The quantity of recharge through the granitic rocks, however, is insignificant relative to recharge through the alluvial fans and stream channels in the valley

Metamorphic rocks are present in both the Sierra Nevada and White Mountains (Moore, 1963, Rinehart and Ross, 1964, Bateman, 1965, Crowder and Sheridan, 1972, Richardson, 1975, Elliott and McKee, 1982, McKee and others, 1982) The metamorphic rocks, of sedimentary and volcanic ongin, consist of slate, phyllite, schist, metaquartzite, metaconglomerate, marble, hornfels, and altered tuffs, breccias, and latite flows The metamorphic rocks in the Sierra Nevada occur as roof pendants, parts of which crop out in the downdropped foothills within Owens Valley (Moore, 1963, Rinehart and Ross, 1964, Bateman, 1965, Richardson, 1975) Equivalent metasedımentary rocks are present in the White and Inyo Mountains (Rinehart and Ross, 1964, Ross, 1965) The correlation of the limited exposures of metasedımentary rocks across Owens Valley suggests that there is a continuity in parts of the bedrock underlying the valley fill $A$ belt of metamorphic rocks in the White Mountains crosses the range near White Mountain Peak and crops out along the White Mountain fault zone (Crowder and Shendan, 1972, McKee and others, 1982) McKee and others (1982) considered these metamorphic rocks to be allochthonous, having been thrust to their present location prior to the plutonic intrusions

The metamorphic rocks of both ranges are dense and have low porosity Foliation and shearing in some locations may increase secondary porosity and hydraulic conductivity, but the limited areal and vertical extent of these rocks reduces the chance of significant recharge to the groundwater system No wells are known to have been developed in the metamorphic rocks of the valley

The lithology, stratigraphy, and distribution of the Proterozoic and Paleozoic sedımentary rocks were extensively described by Kırk (1918), Nelson (1962, 1966a, b), Merriam (1963), Bateman (1965), Ross (1965, 1969), Crowder and others (1972), Crowder and Sheridan (1972), Stınson (1977b), Langenheim and others (1982a), McKee and others (1982), Conrad and McKee (1985), and JE Conrad (U S Geological Survey, written commun, February 1986), they are mapped as undifferentıated sedımentary rocks in figure 7 The dominant sedımentary rocks are marine shale, siltstone, sandstone, limestone, and dolomite, which are well indurated and, relative to the valley fill, are significantly less permeable These sedimentary rocks have been locally metamorphosed where in contact with plutonic rocks (Mernam, 1963, Ross, 1965, McKee and others, 1982, 1985, Conrad and McKee, 1985) The sedımentary rocks are fractured by numerous high- and low-angle faults and may contain small quantities of water along interconnected fractures No known wells have been developed in the sedimentary rocks in the drainage basin area

The Volcanic Tableland, north of Bishop (fig 7), was formed by the Bishop Tuff, which is described by Gilbert (1938) as a pumice and welded ash that onginated in the Long Valley area The Volcanic Tableland consists primarily of an agglutinated member, a welded ash that was fused during implacement (Bateman, 1965) The welded member grades laterally and vertically to an unconsolıdated member The unconsolidated member becomes more prevalent at the distal margins of the Bishop Tuff near Bishop and Laws and is the dominant member buried in the valley fill in the Bishop Basin (Bateman, 1965) This eastern part of the tableland has been mapped by Bateman (1965) as dominantly unconsolidated tuff Most of the Bishop Tuff is underlain by a basal member composed of air-fall pumice that probably was deposited prior to the release of the superheated ash that formed the welded tuff (Bateman, 1965) Bateman (1965, p 155) also recognized that the downward-finıng, horizontally layered sequences of the basal pumice member probably indicate that it was deposited in standing water, supporting the contention of this study that a large lake was present part of the time in the Bishop area during formation of the valley Deposition of the Bishop Tuff predates the collapse of the Long Valley caldera and has been dated at about 09 to 07 million years B P (R A Balley and others, 1976) The mineralogy and petrology of the Bishop Tuff is discussed in more detall by Shendan (1965)

The Volcanic Tableland consists dominantly of the welded member of the Bishop Tuff Except where fractured or composed of consolidated tuff, the tableland is virtually impermeable and therefore has been included as a geologic unit in the bedrock In parts of the tableland, the Bishop Tuff lies in contact with crystalline bedrock This is evident along the north margin of the Bishop Basin, as evidenced in the sequence mapped by Gilbert (1938) in the gorge cut into the tableland by the Owens River The welded and impermeable tuff of the tableland contınues south and east and overlies valley fill of the Bishop Basin (fig 11 and pl 1) The exposed tuff of the tableland generally termınates in abrupt bluffs along the southwest, south, and east margins of the tableland (fig 13) and along Fish Slough Along the south margin of the tableland, the Owens River has eroded through the tuff sequence (pl 1, section $G-G^{\prime}$ ), exposing the basal pumice layer and the underlying valley fill As evidenced from drillers' logs, the Bishop Tuff is present almost $8 \mathrm{~m}$ south, buried in the valley fill as a nearly contınuous bed of unconsolidated tuff and white pumice (pl 1, section $A-A^{\prime}$ ) The unconsolidated tuff and pumice have hydraulic conductivities comparable to fluvial and lacustrine sand in the valley fill (table 1) Recharge of precipitation and runoff through exposed parts of the unconsolidated tuff member is likely, particularly along the Owens River north of Bishop and in the unconsolidated tuff 
east of Fish Slough. Recharge to the valley fill through the welded tuff that composes most of the tableland is unlikely, except along fractures and faults, in the Owens River gorge, and through erosional windows in the tableland.

The Coso volcanic field, at the south end of Owens Valley in the Coso Range and Inyo Mountains, consists of a series of flows and pyroclastic deposits that range in composition from rhyolite to basalt. The field was formed from a series of vent eruptions atop the Coso Range and constitutes a volcanic cap on the mountains (Duffield and Bacon, 1981; Bacon and others, 1982). No wells are known to be present in these volcanic rocks, and their hydrologic characteristics are unknown.

\section{Valley Fill}

The major source of ground water in Owens Valley is from the unconsolidated and moderately consolidated Quaternary sedimentary deposits and interstratified volcanic rocks that fill the valley. The predominant source of the deposits is from the surrounding mountains, in particular the Sierra Nevada. Glaciation of the Sierra Nevada produced abundant sediments that were transported into and deposited in Owens Valley. Perennial streams in the Sierra Nevada have replaced the glaciers and continue to erode the bedrock and transport glacial, alluvial, and colluvial debris from the steep canyons into the valley. Ephemeral streams and debris flows transport a much lesser amount of sediments from the White and Inyo Mountains to the valley floor.

The valley fill is primarily a heterogeneous mixture of unconsolidated to moderately consolidated gravel, sand, silt, and clay that has been entrained, transported, and deposited in the valley by running water, glaciation, and mass wasting. The processes of entrainment, transportation, and deposition are responsible for the lateral and vertical distribution of the valley-fill deposits and, consequently, the hydrologic characteristics of those deposits. Changing depositional environments during the filling of the valley have created a complex arrangement of irregular overlapping and interfingering lenses and layers of fluvial, lacustrine, alluvial fan, littoral, deltaic, colluvial, and glacial deposits. Each depositional sequence has produced a characteristic sediment texture-an orientation, sorting, and grading of sediment grains-that determines the hydrologic characteristics of a particular lens, layer, or body

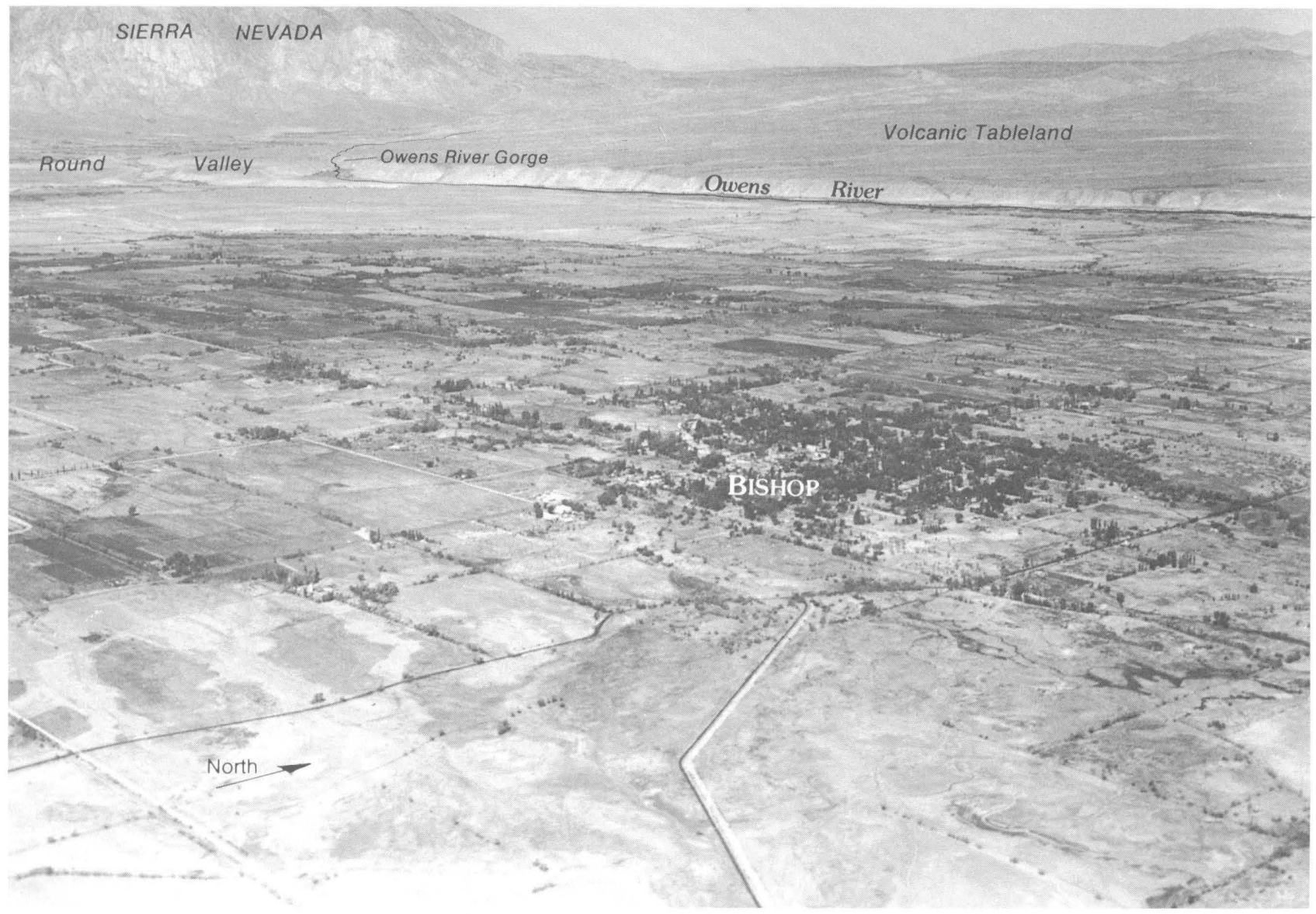

Figure 13. Orientation of the Volcanic Tableland relative to the valley floor in the Bishop area (photographs by Spence Air Photo, August 1931, by permission of the Geography Department, University of California, Los Angeles). 
Table 1. Approxımate range of values of horızontal hydraulic conductivity and specific yıeld for subunits in the valley fill and bedrock in Owens Valley

[Values modified from Davis (1969), Freeze and Cherry (1979), Lohman (1979), and this study --, no data <, less than]

\begin{tabular}{|c|c|c|c|}
\hline Subunits & Typical materials & $\begin{array}{l}\text { Horizontal } \\
\text { hydraulic } \\
\text { conductivity } \\
\text { (feet per day) }\end{array}$ & $\begin{array}{l}\text { Specific } \\
\text { yield }\end{array}$ \\
\hline Alluvial fan deposits . & Mixed clay, silt, sand, and gravel & $10-100$ & $005-015$ \\
\hline Do $\ldots \ldots \ldots \ldots \ldots \ldots$ & Sand and gravel $\ldots$. . . & $20-150$ & $010-025$ \\
\hline Transition-zone deposits . . . . . & Sandy gravel and gravel . . . . . & $50-300$ & $010-030$ \\
\hline Glacial deposits $\quad \ldots \ldots$ & Mixed sand, silt, clay, and gravel & $<10-70$ & -- \\
\hline Talus deposits $\ldots \ldots \ldots \ldots$ & Sand and gravel $\quad \ldots \ldots \ldots \ldots$ & $90-160$ & -- \\
\hline Fluvial and lacustrine deposits . . & Silty clay to clay $\ldots .$. & $0001-30$ & $<001-005$ \\
\hline Do $\ldots \ldots \ldots$.... & Mixed silt, sand, and gravel & $10-120$ & $010-020$ \\
\hline Do $\ldots \ldots .$. & Sand $\quad . \quad$. & $20-150$ & $010-025$ \\
\hline Do $\ldots \ldots \ldots$. . . & Gravel $\ldots \ldots \ldots$. $\ldots$ & $70-250$ & $015-025$ \\
\hline $\begin{array}{l}\text { Olivine basalt of Big Pine } \\
\text { volcanic field. }\end{array}$ & $\begin{array}{l}\text { Brecciated and fractured lava- } \\
\text { flow rocks. }\end{array}$ & $400-12,000$ & $005-030$ \\
\hline Do $\ldots \ldots \ldots \ldots \ldots$ & Dense lava flows . $\ldots \ldots$. & $000003-0000003$ & $<001$ \\
\hline Bishop Tuff $\ldots \ldots \ldots \ldots \ldots$ & Friable ash, pumice, and tuff $\ldots \ldots$ & $20-150$ & $<005-015$ \\
\hline Volcanic Tableland . . . . . . . . & Welded tuff $\ldots \ldots \ldots \ldots \ldots$ & $00001-0.000001$ & $<001$ \\
\hline
\end{tabular}

of sediment Later reworkıng and redeposition of some parts of the valley fill by fluvial and beach processes has further complicated interpretation of the sedımentary sequences Thus, correlation of textural or sedimentary sequences in the valley fill is difficult Even correlation of lithologic data among nearby wells in a given area is difficult

In order to better understand and define the complex interrelation of the many sedımentary sequences in the valley fill, subsurface data from well logs and borehole and surface geophysical methods were correlated to modes of deposition These modes were further correlated to depositional subunits (facies) by use of specific depositional models that explain, in a predictable manner, the modes of sedimentation in the valley fill On the basis of textural, hydrologic, and hydraulic characteristics and modes of deposition, the valley-fill deposits were subdivided into the following depositional subunits younger and older alluvial fans, transition zone between fluvial and lacustrine deposits and alluvial fans, glacial and talus deposits, fluvial and lacustrine deposits, and two intercalated volcanic rock subunits-the olivine basalt of the Big Pine volcanıc field and the Bishop Tuff (pl 2) The hydrologic characteristics of specific textural parts of each subunit (lenses, beds, layers, and massive beds of gravel, sand, silt, or clay) were averaged, using thickness and areal extent of the textural parts to develop composite (vertically averaged) hydraulicproperty values for each particular subunit (table 1) These composite values were verified, to a limited extent, by hy- draulıc coefficients estımated from aquifer tests and single-well pumping tests

\section{Depositıonal Models}

Models of depositional patterns proposed by Miall $(1981,1984)$ provided the basis for the depositional models developed for the valley-fill deposits A number of modes of deposition similar to those described by Miall (1981) are found in the valley No one mode of deposition is dominant, however, because of the abrupt fluctuations from one depositional environment to another caused by climatic changes and tectonic events Miall (1981) superimposed a number of tectonic settıngs on his depositional models, of which only one, that of a "pull-apart" basin, was prominent in the Owens Valley The modes of deposition identified in the valley fill were used to better define the distribution of hydraulic characteristics of the various depositional subunits This technique was particularly useful in areas of the valley where aquifer or single-well pumping-test data were limited but where the depositional subunits were readily definable

The depositional models of Miall $(1981,1984)$ describe the proximal, medial, and distal parts of a generalized paleo-drainage system Streamflow and, consequently, the sedımentary depositional patterns have been simplified 
to either transverse (perpendicular) or longitudinal (parallel) relative to the structural trend of the valley Those specific environments that contributed to the various patterns of deposition in the valley fill of Owens Valley are (1) transverse alluvial fans, (2) either transverse or longitudinal low-sinuosity fluvial (low degree of meanderıng), (3) long1tudinal high-sınuosity fluvial (high degree of meandering) with associated flood plain, (4) longitudinal river-dominated delta, (5) longitudinal littoral beach and bar, and (6) lacustrine The depositional subunits in Owens Valley result from contemporaneous environmental processes that have operated across both modern and relict surfaces of the valley The depositional subunits in the valley fill were defined on the basis of drill hole, geophysical, and geomorphic information and were divided into three generalızed depositıonal models to and in defining the hydrologic regimes and the distribution of hydraulic characteristics The models are 11lustrated in figure 14 and briefly described below

Model 1 Alluvial fan to fluvial and lacustrine plain to trunk river - This model consists of a single fan or apron of coalesced alluvial fans that build out onto a fluvial or lacustrine plain and are incised by a single, meandering trunk river The alluvial fan(s) are deposited transverse to the axis of the valley and the trunk stream The lacustrine sediments exposed at the surface were deposited during the last high lake level during the Pleistocene Holocene alluvial fans have buried the ancient lake shore Fluvial erosion and deposition dominate the model Low-sinuosity tributary streams incise the alluvial fans, redeposit material at the toe of the fans, and intersect the trunk stream transversely Terraces in the center of the valley are moderately developed by the trunk stream, and the coincident delta is small and localized This depositional model describes the present condition in Owens Valley

Model 2 Alluvial fan to lake - The depositional pattern in this model is a single fan or apron of coalesced alluvial fans deposited transverse to a lake margin Medial alluvial fan material is deposited by tributary streams and sheetwash at the margin of the lake Fine material is transported out into the lake, where it settles Well-sorted medium to coarse sand and gravel form longitudinal beach and bar deposits along the lake margin This model represents the depositional system as it probably was in the valley during the last pluvial period of the Pleistocene

Model 3 Alluvial fan to trunk river to lake margin with localized river-dominated delta - This model depicts a single fan or apron of coalesced alluvial fans that build onto a river-dominated flood plain incised by a gradational lowto high-sinuosity trunk stream that flows to a lake Delta buildup is locally dominant but not vertically extensive Fluctuations in lake level, coupled with tectonic activity, produce alternating vertical sequences of coarse sediments associated with distal alluvial fan and transition-zone deposits and fine lacustrine deposits near the toe of the alluvial fans This depositional pattern is representative of the transition period that occurred between deposition of deposits that are represented by models 1 and 2

\section{Alluvial Fan Deposits}

Alluvial fan deposits interfinger with the west and east sides of the valley-center fluvial and lacustrine deposits through the transition zone (pl 1) The valley alluvial fan deposits have been described by a number of investigators (W T Lee, 1906, Trowbridge, 1911, C H Lee, 1912, Knopf, 1918, Beaty, 1963, Bateman, 1965, Ross, 1965, Gillespie, 1982) A description of the morphologic and lithologic differences between the various types and ages of fans in the valley by Trowbridge (1911), Knopf (1918), and Gillespie (1982) was used as the basis for fan characterization in this report (fig 7) The alluvial fans in Owens Valley are characterized as older or younger on the basis of surface morphology and degree of induration The older alluvial fans are dissected and entrenched by modern stream channels and overlain in part by younger alluvial fans These older fans are more indurated and therefore less permeable than the younger fans The entrenchment of tributary streams in older alluvial fans along the Sierra Nevada has resulted in the formation of younger alluvial fans and a shift in deposition away from the mountains (Gillespie, 1982) The younger alluvial fans are deposited over the margin of older fluvial and lacustrine deposits Buried beneath the younger fans are older fan deposits that, in parts of the valley, are in contact with transition-zone deposits

The older alluvial fans are composed of a mixture of fine to very coarse colluvium transported by debris flows from the mountain valleys to the heads of the alluvial fans (Blackwelder, 1928, Beaty, 1963, Trowbridge, 1911) The result is an extremely heterogeneous, poorly sorted, deposit with a matrix of silt and clay that is distributed in a radial pattern away from the canyon mouth and laps onto the valley floor Sections of the older alluvial fans along the Sierra Nevada are exposed in the banks of tributary streams that incise the fans Outcrops and logs from drill holes that penetrate the alluvial fans indicate that the older alluvial fan deposits are poorly sorted and display indefinite bedding The older alluvial fan deposits are moderately consolidated, but the extent of consolidation is not uniform throughout the fan The consolidation does, however, produce hydraulic conductivities and specific yields in the older alluvial fan deposits that are lower than those in the younger alluvial fan deposits

The younger alluvial fans, located primarily along the west side of the valley, tend to be better sorted and have better defined beddıng than the underlyıng, older alluvial fans This difference may be partly due to more mudflow deposits within the younger alluvial fan material, which are typical in alluvial fan formation described by Rachockı (1981) The younger alluvial fans are unconsolidated and, where saturated, yield more water to wells than the older 


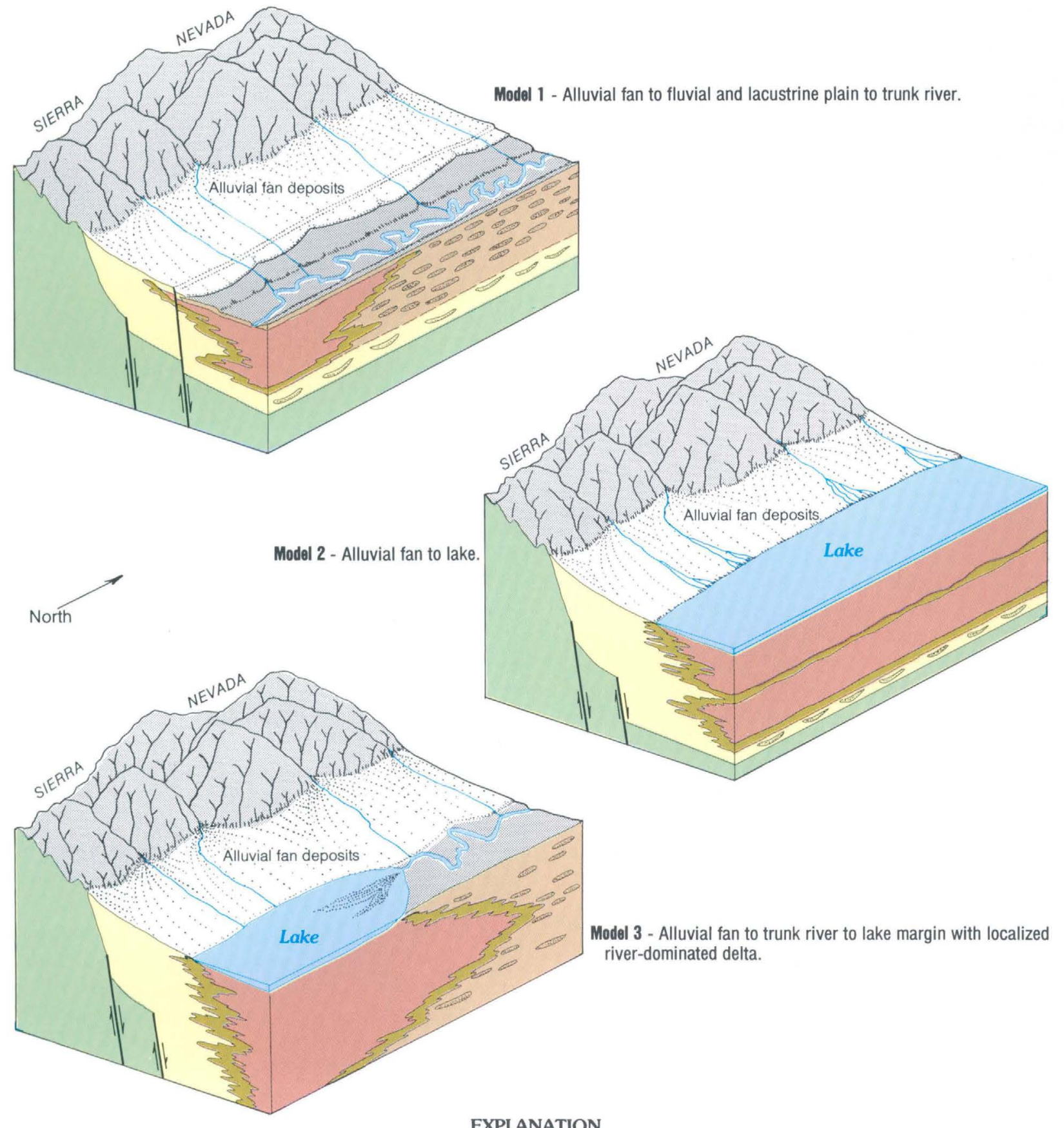

EXPLANATION

(Drawings are greatly simplified-glacial and talus deposits and volcanic rocks are not shown)

ALLUVIAL FAN DEPOSITS,
UNDIFFERENTIATED - Includes younger
and older fan deposits, transverse cut-andchannel deposits indicated by lens symbol

\section{TRANSITION-ZONE DEPOSITS-}

Includes beach and bar deposits
FLUVIAL AND LACUSTRINE

\section{DEPOSITS-}

Lacustrine deposits-Includes deltaic deposits

Fluvial deposits - Includes channel gravels and overbank deposits

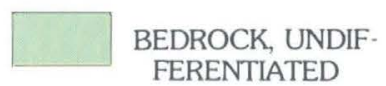

FERENTIATED

\section{FAULT - Arrows}

indicate relative vertical movement

Figure 14. Schematic drawings of the generalized depositional models in the valley fill in Owens Valley. 
alluvial fan deposits Because the younger alluvial fans are moderately layered, horizontal hydraulic conductivity is generally greater than the vertical conductivity The approximate ratios, however, have not been determined On the basis of aquifer tests in similar material in Arizona (Hollett and Marie, 1986), the ratio of horizontal to vertical hydraulic conductivity is estimated to be between 10 and 20 to 1 Owing to the poorly sorted alluvial fan deposits, the horizontal hydraulic conductivity is low, it ranges from 1 to $30 \mathrm{ft} / \mathrm{d}$ but may be as high as $100 \mathrm{ft} / \mathrm{d}$ in localized areas (table 1) Specific yield is generally less than 015

The younger, undissected and older, dissected alluvial fans along the White and Inyo Mountains (fig 7) generally have sımılar hydrologic characteristics to those of the older alluvial fans of the Sierra Nevada The older, dissected allu-vial fans of the White Mountains in the Bishop Basin east of Big Pine (Waucobı Embayment) are typically fault terminated at the base of the mountains (fig 7) The older alluvial fan remnants on the upthrown bedrock block are dissected by intermittent streams Faults, which have juxtaposed finer Waucobi Lake deposits with the older alluvial fans in the Waucobi Embayment, deflect ground water that flows toward the center of the valley etther to the surface as springs or deeper into the valley fill beneath confining beds in a manner similar to that of the longitudinal faults observed on the west side of the Owens Lake Basin A few springs near the mouth of the Waucobi Embayment have been observed, but the discharge either evaporates rapidly or returns to the valley fill on the west side of the fault

\section{Transition-Zone Deposits}

Along the margin of the valley floor in both the Bishop and Owens Lake Basins, a transition zone of longitudinally onented lenses of coarse sediment is present in the subsurface between the fluvial and lacustrine and alluvial fan deposits (pl 1) This zone is well developed in the subsurface on the west side of the valley along the toes of the coalesced alluvial fans (pl 1) A limited and less extensive transition zone probably occurs along the east margin of the valley, but the data are limited or not definitive The transition zone is recognized in well records and logs by stringers of well-sorted sandy gravel or cobble layers These layers are characterized by better sortıng, farly contınuous north to south correlation, and greater hydraulic conductivity than the poorly sorted alluvial fan sedıments that are deposited transversely (Trowbridge, 1911, Gillespie, 1982) or the basin-center fluvial and lacustrine deposits (fig 8 and table 1 ) The continuity of the transition zone is interrupted by transverse cut-and-fill deposits left by recent and ancient tributary streams and deltas common to alluvial fans described by McPherson and others (1987) Layering in the transition zone also is enhanced by silty-clay and clay lenses derived from mud flows that typically occur in formation of alluvial fans (Rachock1, 1981) The north-tosouth onentation of the transition-zone deposits suggests that they are a combination of beach, bar, or river-channel sediments As beach sediment, these deposits delineate the ancient lake margin in depositional models 2 or 3 If fluvial sediments, they would best fit either depositional models 1 or 3 Knopf (1918) and Lubetkın and Clark (1985) reported beach sedıments in the valley fill of Owens Lake Basin Knopf (1918) described a 10-foot-high surficial bar in the Owens Lake Basın that consists of well-rounded, shingled, and honzontally stratıfied gravel Beach sediments also have been reported in other lake basins in the Pleistocene Owens River drainage system (Russell, 1889, Mayo, 1934, Blackwelder, 1954, Hunt and Mabey, 1966, Smith, 1979) Hunt and Mabey (1966) described nearshore gravel bars in Death Valley as being $20 \mathrm{ft}$ high, $500 \mathrm{ft}$ wide, and 025 to $050 \mathrm{ml}$ long

In parts of the valley, the longitudinal transition zones can be identıfied by a discontınuous line of springs, particularly along the west margins near the toes of alluvial fans These springs were first noted by C H Lee (1912) Some of the springs and seeps probably are caused by an abrupt decrease in honzontal hydraulıc conductivity such as will occur from transition zone sandy gravel or highly permeable volcanic rocks to lacustrine silt and clay Abrupt changes in horizontal hydraulic conductivity also can occur between materials in the valley fill that are juxtaposed one to another by displacement along faults Hydraulic conductivity of sandy-gravel stringers in the transition zone generally ranges from 50 to $300 \mathrm{ft} / \mathrm{d}$ and in olivine basalts of the Big Pine volcanic field from 400 to $12,000 \mathrm{ft} / \mathrm{d}$, in lacustrine silt and clay, the hydraulic conductivity ranges from 0001 to $30 \mathrm{ft} / \mathrm{d}$ (table 1) These abrupt changes in hydraulic conductivity force ground water moving from the mountain areas either to the surface or to flow beneath the lacustrine clay layers Hunt (1974) observed a similar phenomenon in Death Valley

The most prominent line of springs in the valley is evident along the west side of the valley on a line that extends from north of Alabama Hills to near Poverty Hills South of Independence, most of the springs overlie the valley side of a sandy-gravel transition zone or are associated with longitudinal normal faults North of Independence and south of Poverty Hills, springs and seeps are associated with abrupt changes in hydraulic conductivity where basalt flows are juxtaposed by lacustrine clay layers or along normal faults where fluvial and lacustrine deposits are juxtaposed In each case, the occurrence and onentation of springs and seeps aided in identifying subsurface horizontal changes in hydraulic conductivity, owing to structure or change in depositional subunits

Glacıal and Talus Deposits

Alpine glaciation of the Sierra Nevada during and since the Pleistocene has left extensive glacial deposits in 
the form of moraines in the tributary-stream valleys (Moore, 1963, Bateman, 1965, Gillespie, 1982) (fig 7) A few moraines extend onto the heads of the alluvial fans, but extensive moraines that protrude from the mountain front, common in Round Valley and areas farther north, are noticeably absent in the Owens Lake Basin The moraines consist of poorly sorted, unstratıfied drift Runoff that infiltrates the moraines which mantle the heads of the fans either provides base flow to perennial streams or recharge to the alluvial fan No wells are known to tap these glacial deposits

Talus is found as small isolated patches of coarse sand and angular blocks of varied sizes, some as large as boulders, at the base of steep canyon walls or at scattered locations along the base of the Sierra Nevada The deposits generally lie on the heads of alluvial fans or are buried by subsequent alluvial deposition The talus deposits are generally unsaturated, and any infiltratıng water flows rapidly through the loosely packed coarse material to the adjacent stream, moraine, or alluvial fan

\section{Fluvial and Lacustrıne Deposıts}

The fluvial and lacustrine deposits of Owens Valley constitute most of the valley fill along the axis of the valley (fig 7 and pl 1) These deposits consist of interbedded gravel, sand, silt, and clay whose form is controlled by either depositional model 1,2 , or 3 Beds commonly interfinger or are present as lenses within other beds Exposures of these beds and lenses are seen in the banks of the incised channel of the Owens River and are most prominent in the Owens Lake Basın Exposures in the Bishop Basın are lımited to isolated banks and terraces along the river Additional data for the surface geology were derived from soll pits and auger holes Interpretation of the shallow beds was extended into the subsurface by the use of well logs and borehole and surface geophysical data

The fluvial and lacustrine deposits incorporate all or part of the lacustrne and valley-fill deposits of Knopf (1918), lacustrine deposits of Marliave (1934), the valley fill of Ross (1965) and Nelson (1966a, b), the alluvium, the terrace gravel, and the few small sand dunes associated with the terrace gravel west of Bishop of Bateman (1965) The older alluvium and terrace gravel described by Bateman (1965) are generally crudely stratıfied layers of poorly sorted sand and cobbles Bateman reported that gravel of the older terrace alluvium is coarser than the present channel gravel of the Owens River and suggested that the gravel was deposited by the large, fast-flowing rivers of the Pleistocene Generally, the gravel de-posits grade from coarse texture in the Bishop Basin to finer texture in the Owens Lake Basin Sedıment at the surface in the Bishop and Big Pine areas is mainly sand and silty-sand fining to a sandy-silt and clay in the Independence area
Few contınuous beds or lenses of simılar texture in the fluvial and lacustrine deposits can be reliably correlated over large distances, indicatıng that the beds and lenses are generally lenticular This lenticular form is repeated continuously, both vertıcally and areally, across the valley and produces a characteristic interfingering and overlapping form in most areas These characteristics are generally the result of either meandering channels of depositional model 1 or shallow, lacustrine-delta sequences of model 3 Depositional model 2 usually produces massive silt and clay beds with intercalated lenses of bar sand and gravel

In one part of the fluvial and lacustrine deposits a massive clay layer can be correlated over a large area of the valley Lacustrine blue and green clay layers in the subsurface south of Big Pine extend over most of the southern part of the Bishop Basin (fig 12) These clay beds represent depositional model 2 in the southern part of the Bishop Basin and were defined on the basis of characteristic borehole geophysical signatures and megascopic textural and color characteristics of drill cuttıngs in hand specimen The green clay is not found in the fluvial and lacustrine deposits of the Owens Lake Basın south of the "narrows" The blue and green clays were deposited as a part of the fluvial and lacustrine deposits in the Bishop Basin in a lake that was dammed by an episode of volcanic eruptions from the Big Pine volcanıc field and, to a lesser extent, by structural offsets created by faulting The lower blue clay is in contact with the green clay in Bishop Basin, and together they form a single bed of blue-green clay about $100 \mathrm{ft}$ thick beginning at a depth of about $175 \mathrm{ft}$ below land surface (fig 12) The upper and lower blue clay layers can be distınguished from a green clay layer by higher natural gamma intensities The different gamma intensities probably are the result of different states of radioactive decay of the radiogenic minerals in the blue and green clays General thickenıng of the blue clay to the west suggests a young source rock in the Sierra Nevada Thickening green clay to the east, however, suggests a source in the older more radiogenically depleted olıve-green Paleozoic marine shales of the White Mountains The blue and blue-green clay layers are contınuous throughout the southern part of Bishop Basin and are distınguishable from other valley-fill material by their geophysical signatures and geological characteristics These layers thin to the north from the "narrows," opposite Poverty Hills

The hydrologic character of the heterogeneous fluvial and lacustrine deposits in the Bishop Basin is highly variable An analysis of nıne well logs that include depths ranging from 200 to $700 \mathrm{ft}$ of the fluvial and lacustrine deposits in the Bishop Basin indicates that about 21 percent of the deposits were described as "gravel" beds These gravel beds are principally fluvial The average thickness of these gravel beds is $14 \mathrm{ft}$, the most common thickness is $3 \mathrm{ft}$ The thickness of gravel beds ranged from 2 to $74 \mathrm{ft}$ With exception of some massive beds of clay and intercalated volcanic rocks 
in the Bishop Basin (pl 1), zones of overlapping and isolated lenses of silty-clay and clay generally are present throughout the sand and gravel of the fluvial and lacustrine deposits The combined effect of the layered gravel and sand with interlayered silty-clay and clay lenses produces a heterogeneous subunit with horizontal hydraulic conductivities that range from 70 to $120 \mathrm{ft} / \mathrm{d}$ in the Bishop Basin Vertical hydraulic conductivities range from one-tenth to one-thirtieth the horizontal conductivities in the subunit

In Owens Lake Basin, well and borehole geophysical logs indicate that the layered sediment generally consists of alternatıng gravel, sand, silty-clay, and clay beds and lenses similar to the layered sequences in the Bishop Basin However, the overall grain size of the subunit in the Owens Lake Basin is finer than in the Bishop Basin Peat also has been noted in the subunit by some drillers in logs of wells east of Independence Peat probably is associated with a depositional pattern similar to models 1 or 3 Hydraulic conductivities of fluvial and lacustrine deposits in the Owens Lake Basin range from $100 \mathrm{ft} / \mathrm{d}$ in moderately to well-sorted sand and gravel to less than $30 \mathrm{ft} / \mathrm{d}$ in poorly sorted sands and silts Massive clay beds in the Owens Lake Basin are generally associated with long periods of lacustrine deposition (model 2), such beds are the thick sequences of bedded clays associated with Pleistocene Lake Owens and Holocene Owens Lake A log for an 823-foot-deep Lone Pine Station (rallroad) well located east of Lone Pine that intersects these clay beds (section $F-F^{\prime}, \mathrm{pl} 1$ ) records only one 6-foot-thick bed of "gravel with mixed sand and clay" A 920-foot drill core in Owens Lake (dry) records no gravel for its entire length (Smith and Pratt, 1957) In the analysis of the 920-foot Owens Lake core, clay accounted for 48 percent of the beds with an average thickness of $15 \mathrm{ft}$ and 22 percent was sand with an average bed thickness of $11 \mathrm{ft}$ The most frequently occurring bed thickness for both clay and sand was $3 \mathrm{ft}$

\section{Olıvıne Basalt of Bıg Pıne Volcanıc Field}

The olıvine basalt of Big Pine volcanıc field, and parts thereof, has been described by numerous investigators (W T Lee, 1906, Knopf, 1918, Mayo, 1934, Moore, 1963, Pakıser and others, 1964, Bateman, 1965, D E Williams, 1966, 1969, Gillespie, 1982) It is composed of olivine basalt lava flows and cinder cones that have generally erupted along faults (figs 7 and 15) One rhyolitic dome (fig 15) is present within the volcanic field west of the Poverty Hills and is more lithologically similar to the Bishop Tuff than the olivine basalt of the Big Pine volcanic field This dome is of limited surface extent and does not constitute a significant subunit of the valley fill It probably acts more as a slight deflector of ground water that flows downgradient west of the Poverty Hills

On the basis of weathering patterns, the olivine basalt flows and cinder cones of the Big Pine volcanic field have a Holocene appearance, but generally they are of Pleistocene age and have large sections partly buried by older alluvial fan deposits (pl 1 , sections $C-C^{\prime}, D-D^{\prime}$, and $H-H^{\prime}$ ) The buried and saturated basalt flows in the valley are highly transmissive and are the most permeable subunit in the ground-water system The movement of ground water in the flows is facilitated by extensive clinker zones, flow-top rubble, flow breccia, pyroclastic beds, lava tubes, and shrinkage cracks (Wood and Fernandez, 1988) The burned flows overlap one another and form a discontınuous horizontal network of flows in the subsurface (sections $C-C^{\prime}$, $D-D^{\prime}$, and $H-H^{\prime}, \mathrm{pl}$ 1) The vertical distribution and character of the flows are less well known On the east side of the valley, the buried basalts were extruded along fault zones that cut the upper slopes of the older alluvial fans and flowed downslope toward the valley center forming a series of overlapping tongues of volcanic rock The lava flows, which are interlayered with the valley-fill deposits, receive their recharge in the upper slopes of the alluvial fans and provide a conduit for rapid movement of ground water toward the valley center Wells that principally tap volcanic flows of the Big Pine volcanic field are capable of yielding thousands of gallons per minute for sustained periods with minimal drawdown Hydraulic conductıvities for the saturated olivine basaltic rocks in the Big Pine volcanic field range from about $400 \mathrm{ft} / \mathrm{d}$ to $12,000 \mathrm{ft} / \mathrm{d}$ and average about 3,000 $\mathrm{ft} / \mathrm{d}$ (table 1)

\section{Bishop Tuff}

South of the Volcanic Tableland, the Plesstocene Bishop Tuff is interstratified with the fluvial and lacustrine beds in the Bishop Basin Bateman (1965) suggested that the buried tuff is composed of the basal pumice and overlying unconsolidated tuff members Bateman (1965) described in detall the subsurface structure and distribution of the Bishop Tuff The tuff lies at increasing depths southward in the Bishop Basin and progressively thins to the south as well as to the east and west margins of the basin (pl 1, sections $A-A^{\prime}$ and $G-G^{\prime}$ ) Northwest of Bishop and south of the Owens River, the basal pumice and unconsolidated tuff members are overlain by coarse fluvial terrace gravel, and the consolıdated tuff is noticeably absent (Bateman, 1965) This relation suggests that a part of the thinning of the Bishop Tuff in the Bishop Basin is erosional rather than depositional The "hard tuff" member described by some well drillers in the Bishop Basın may be the erosional remnant of the welded tuff or erosional mounds of welded tuff similar to those mapped on the surface of the Volcanic Tableland (Bateman, 1965) The hydraulic properties of the basal pumice and unconsolidated tuff layers are believed to be similar to the fluvial and lacustrine sand deposits (table 1) and are considered to be good aquifer materials (Tolman, 1937, Bateman, 1965) 


\section{WATER RESOURCES}

\section{Surface Water}

\section{Source, Routing, and Discharge}

The primary source of surface water in Owens Valley is precipitation that falls on the slopes of the Sierra Nevada, forming small rivulets which in turn form tributary streams. These streams flow down mountain canyons, across the alluvial fans, and out onto the valley floor. In the Bishop Basin, the tributary streams are captured by the trunk stream of the valley, the Owens River, which has its headwaters in Long Valley. In the Owens Lake Basin, the streams are diverted into the Los Angeles Aqueduct about 2 mi west of the natural channel of the lower Owens River. The combined waters of the river-aqueduct system and the diverted tributary streams are routed south out of the valley through Haiwee Reservoir. Any water remaining in the lower Owens River flows into Owens Lake (dry) and evaporates. The
Owens Valley drainage basin area, its tributaries, and the river-aqueduct system are shown in figure 16.
Tributary Streamflow

Many of the natural channels of tributary streams have been modified by the Los Angeles Department of Water and Power for operation of the river-aqueduct system. Nearly all streams have had diversion structures installed, and some streams, such as Goodale Creek, have had parts of their natural channels straightened. Other streams, namely Bishop Creek, Thibaut Creek, Division Creek, and Coldwater Canyon Creek, are diverted to pipes for much of their length. In the Bishop Basin, most of the tributary streamflow that reaches the valley floor is diverted to canals that distribute water for agricultural uses, wildlife habitat areas, or ground-water recharge. Excess water is returned to the canals and eventually to the Owens River. Approximately $5 \mathrm{mi}$ downstream (south) of Tinemaha Reservoir, the Los Angeles Department of Water and Power

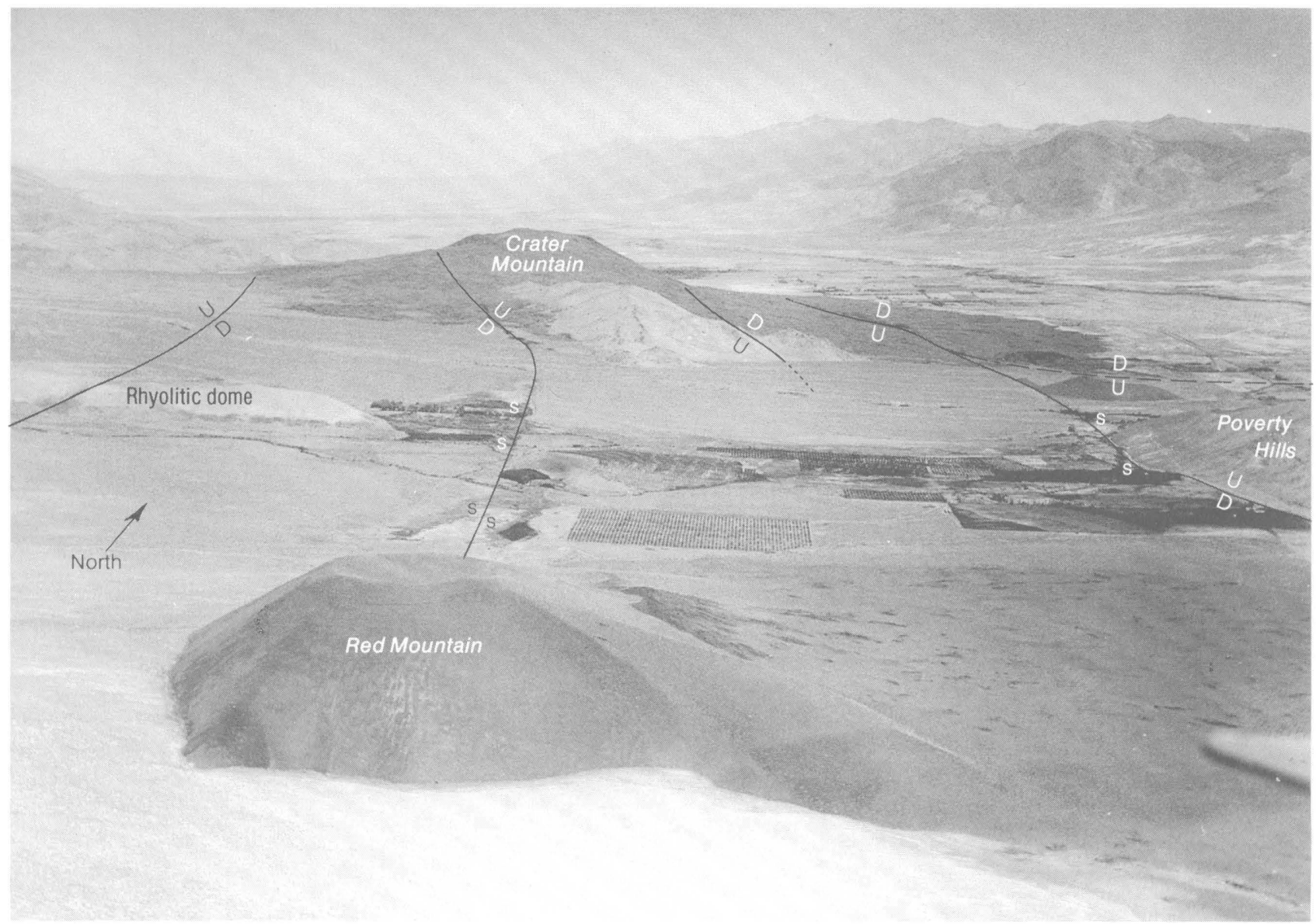

Figure 15. Alignment of volcanic cones (Crater and Red Mountains), rhyolitic dome, and springs (s) along the faults in the Poverty Hills area of Owens Valley. Relative direction of vertical movement on faults is shown as downthrown side (D) and upthrown side (U) (photographs by Spence Air Photo, August 1931, by permission of the Geography Department, University of California, Los Angeles). Faults dotted where inferred. 


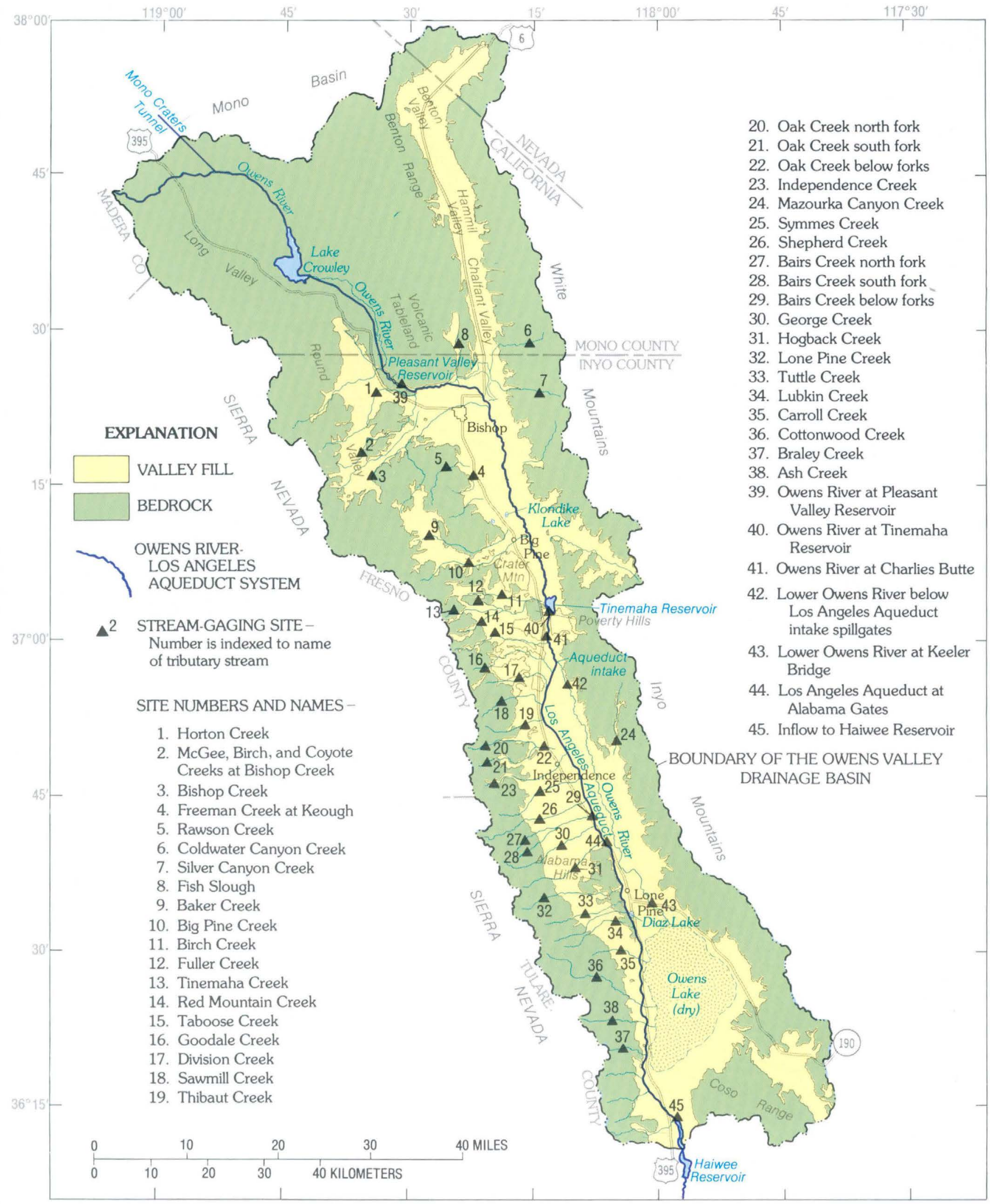

Figure 16. Owens Valley drainage basin area and surface-drainage patterns for tributary streams, Owens River, and Owens RiverLos Angeles Aqueduct system. 
diverts nearly all streamflow into the Los Angeles Aqueduct The upstream end of the Los Angeles Aqueduct is referred to as the intake Any water not diverted into the aqueduct continues to flow east of the aqueduct in the natural channel of the lower Owens River In years of average runoff, little or no surface water flows to the lower Owens River Durnng wet years when surface water is abundant, tributary streamflow exceeds the capacity of the river-aqueduct system, and some of the tributary streamflow either is diverted onto the alluvial fans to recharge the ground-water system or is allowed to contınue flowing across the valley floor toward the lower Owens River

Tributary streamflow in Owens Valley is gaged contınuously by the Los Angeles Department of Water and Power at more than 60 sites on 34 tributaries On many of the tributaries, at least two sites are gaged Typically, one gage is located at the base of the mountains, and the other is located close to the river-aqueduct system The location of gages at the base of the mountains and a selected few at the nver-aqueduct system are shown in figure $16 \mathrm{~A}$ complete record at these sites, except for occasional short gaps, 1s avallable for water years 1934-87 (Los Angeles Department of Water and Power, written commun, 1987) A 50year period of record, water years 1935-84, was used for the analyses in this report and in the related numerical evaluation of the hydrologic system (W R Danskın, U S Geological Survey, written commun , 1988)

Table 2 summarızes maxımum, mınımum, and mean annual discharge at the base-of-mountains and nver-aqueduct sites for contınuously gaged tributanes withın Owens Valley Between the two sites, the tributary streams generally lose water' as a result of streambed leakage, diversions of streamflow onto the alluvial fans, and, to a lesser extent, evapotranspiration from areas along the stream channel Several streams also receive water from pumped wells just upstream of the river-aqueduct site, and a few streams receive water from springs, canals, or diversions from other streams Some streams may gain water in lower reaches because of local seepage of ground water caused by faults, shallow bedrock, or changes in the hydraulic characteristics of the depositional material Although discharge at the baseof-mountains and river-aqueduct sites is gaged contınuously and well pumpage is metered, other gains to or losses from tributary streams generally are not measured or are not measured contınuously

Mean annual discharge for tributaries measured at baseof-mountains gaging stations ranged from 51 to 67,748 acre- $\mathrm{ft}$ (table 2) Individual tributanes having the greatest flow include Bishop, Big Pine, Cottonwood, Independence, and Lone Pine Creeks Mean annual discharge for most streams was about 6,000 acre-ft Maxımum and minımum mean annual discharge values given in table 2 illustrate the general range of flow conditions duning the 50-year period of record, but these annual values can mask periods of even higher or lower flows occurring within a single year The extreme variability in streamflow among the tributanes is a result of differing dranage basin area, quantities of precipitation per area, and rates of infiltration

Owens River and Los Angeles Aqueduct System

The river-aqueduct system extends from Mono Basin to Haiwee Reservorr (fig 1) Stream-discharge data for selected stations along the river-aqueduct system between Pleasant Valley Reservorr and Haiwee Reservorr are summarized in table 3

At the northernmost point of the river-aqueduct system in Mono Basin, streams flowing out of the Sierra Nevada are diverted into a concrete-lined channel The diverted water is routed to Grant Lake in Mono Basin and eventually is conveyed to the Owens River in Long Valley through the Mono Craters Tunnel, an 11 3-mile-long tunnel (figs 1 and 16) The mean annual discharge through the tunnel is about 72,000 acre-ft At the end of the Mono Craters Tunnel, water from Mono Basin joins the upper reach of the Owens River and together flows about $12 \mathrm{ml}$ to Lake Crowley, also known as Long Valley Reservoir Lake Crowley, which is the largest reservoir in the river-aqueduct system, regulates the flow of water through a pipeline that connects Lake Crowley in Long Valley with Pleasant Valley Reservoir in Owens Valley (fig 16) The natural channel of the Owens River through the Volcanic Tableland is used infrequently to convey flood waters or to divert water during maintenance of the pipeline Three hydroelectric plants located along the pipelıne generate electricity as a result of a drop in altitude of $1,600 \mathrm{ft}$ from Long Valley to Owens Valley The mean annual discharge of the Owens River at Pleasant Valley Reservour was 271,871 acre-ft for water years 1935-84 (table 3) Maxımum and mınımum annual flows were 444,436 and 165,634 acre-ft, respectıvely

Pleasant Valley Reservorr regulates flow to the natural channel of the Owens River downstream from the spillgates of Pleasant Valley Dam The Owens River contınues south, gaining water from tributary streams and from pumped and flowing wells, before discharging into Tinemaha Reservorr at the south end of Bishop Basin The mean annual discharge of the Owens River at Tinemaha Reservoir was 354,537 acre-ft for water years 1935-84 Flow in the Owens River resumes south of the reservoir and contınues for approximately $5 \mathrm{mi}$ until virtually all water is diverted into the unlıned channel of the Los Angeles Aqueduct Flowing along the toes of the western alluvial fans, the aqueduct gains additional water from streams and wells At Alabama Gates, on the north side of Alabama Hills, the aqueduct changes to a concrete-lined channel, and the mean annual discharge was 369,603 acre-ft for water years 1945-84 By the time the aqueduct reaches Hawwee Reservoir, at the southern boundary of the study area, mean annual discharge is 391,023 acre-ft, or about 15 tımes the mean annual discharge at Pleasant Valley Reservoir Hawwee Reservour regulates and temporarly stores water before 
Table 2. Maxımum, mınımum, and mean annual dıscharge measured at base-of-mountaıns and Owens Rıver-Los Angeles Aqueduct system gagıng statıons for tributary streams in Owens Valley, water years 1935-84

[Discharge data from Los Angeles Department of Water and Power (written commun, 1985) --, no data Discharge in acre-feet per year]

\begin{tabular}{|c|c|c|c|c|c|c|c|c|}
\hline \multirow{2}{*}{$\begin{array}{c}\text { Site } \\
\text { No } \\
\text { (fig 16) }\end{array}$} & \multirow[t]{2}{*}{ Name } & \multicolumn{3}{|c|}{$\begin{array}{c}\text { Stations at } \\
\text { base of mountains }\end{array}$} & \multicolumn{3}{|c|}{$\begin{array}{c}\text { Stations at } \\
\text { Owens Ruver-Los Angeles } \\
\text { Aqueduct } \\
\end{array}$} & \multirow[t]{2}{*}{ Remarks } \\
\hline & & Maximum & Minımum & Mean & Maxımum & Mınımum & Mean & \\
\hline 1 & Horton Creek & 13,520 & 2,900 & 6,138 & 21,549 & 2,814 & 7,380 & -- \\
\hline \multirow[t]{2}{*}{2} & McGee, Birch, and Coyote & & & & & & & \\
\hline & Creeks at Bishop Creek & 15,220 & 7,142 & 11,140 & - & - & - & -- \\
\hline 3 & Bıshop Creek & 120,148 & 32,665 & 67,748 & - & - & -- & $\left({ }^{1}\right)$ \\
\hline 4 & Freeman Creek at Keough & - & - & - & 650 & 0 & 45 & - \\
\hline 5 & Rawson Creek & 1,727 & 960 & 1,347 & - & - & -- & -- \\
\hline 6 & Coldwater Canyon Creek & 1,384 & 423 & 741 & - & $\ldots$ & - & $\ldots$ \\
\hline 7 & Silver Canyon Creek & 2,556 & 488 & 1,233 & -- & -- & -- & $\left(\begin{array}{l}2 \\
)\end{array}\right)$ \\
\hline 8 & Fish Slough & 7,877 & 5,176 & 6,066 & 7,050 & 1,431 & 5,248 & $(3)$ \\
\hline 9 & Baker Creek & 17,946 & 2,998 & 6,212 & - & -- & - & $(1)$ \\
\hline 10 & Bıg Pıne Creek & 60,838 & 19,059 & 31,334 & 49,923 & 8,354 & 22,079 & $\ldots$ \\
\hline 11 & Bırch Creek & 11,384 & 2,895 & 5,559 & 8,335 & 0 & 2,316 & $\left({ }^{4}\right)$ \\
\hline 12 & Fuller Creek & 378 & 2 & 143 & - & -. & -- & $\ldots$ \\
\hline 13 & Tinemaha Creek & 10,966 & 2,358 & 5,741 & 12,126 & 2,113 & 7,202 & 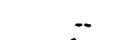 \\
\hline 14 & Red Mountain Creek & 8,097 & 1,431 & 3,829 & -- & - & -- & $\left({ }^{1}\right)$ \\
\hline 15 & Taboose Creek & 12,352 & 3,691 & 6,685 & 19,318 & 634 & 5,325 & $(1,5)$ \\
\hline 16 & Goodale Creek & 9,493 & 2,623 & 5,194 & 14,860 & 257 & 3,167 & $\left(\begin{array}{l}5 \\
5\end{array}\right)$ \\
\hline 17 & Division Creek & 6,104 & 1,582 & 4,433 & 6,749 & 87 & 3,698 & $(1,5)$ \\
\hline 18 & Sawmıll Creek & 8,528 & 1,895 & 3,840 & 3,893 & 1,052 & 2,153 & $\left({ }^{5}\right)$ \\
\hline 19 & Thibaut Creek & 1,205 & 3 & 371 & -- & - & -- & $(1,6)$ \\
\hline 20 & Oak Creek, north fork & 11,194 & 3,339 & 7,104 & -- & - & -- & $(1)$ \\
\hline 21 & Oak Creek, south fork & 7,996 & 1,693 & 4,888 & -- & -- & -- & $\left({ }^{1}\right)$ \\
\hline 22 & Oak Creek, below forks & - & - & - & 7,447 & 0 & 633 & - \\
\hline 23 & Independence Creek & 21,322 & 3,184 & 10,133 & 9,003 & 66 & 2,932 & -- \\
\hline 24 & Mazourka Canyon Creek & 457 & 0 & 51 & - & - & - & $\left({ }^{7}\right)$ \\
\hline 25 & Symmes Creek & 6,058 & 696 & 2,799 & 276 & 0 & 30 & $(1)$ \\
\hline 26 & Shepherd Creek & 16,597 & 2,619 & 7,865 & 9,618 & 1,071 & 4,398 & $(5)$ \\
\hline 27 & Bairs Creek, north fork & 5,823 & 546 & 2,094 & -- & - & -. & -- \\
\hline 28 & Bairs Creek, south fork & 5,413 & 345 & 1,665 & -- & - & -- & -- \\
\hline 29 & Bairs Creek, below forks & - & -- & - & 2,375 & 0 & 528 & $\left({ }^{5}\right)$ \\
\hline 30 & George Creek & 13,562 & 2,285 & 6,444 & 6,420 & 0 & 2,271 & $(1,5)$ \\
\hline 31 & Hogback Creek & 7,835 & 950 & 2,978 & 2,658 & 0 & 766 & - \\
\hline 32 & Lone Pine Creek & 21,280 & 4,848 & 9,417 & 16,393 & 0 & 3,294 & -- \\
\hline 33 & Tuttle Creek & 11,699 & 2,794 & 5,562 & 5,857 & 0 & 808 & $\left({ }^{8}\right)$ \\
\hline 34 & Lubkın Creek & - & -- & - & 1,891 & 113 & 412 & - \\
\hline 35 & Carroll Creek & -- & -- & -- & 1,545 & 0 & 254 & -- \\
\hline 36 & Cottonwood Creek & 50,447 & 3,196 & 16,406 & 44,549 & 0 & 9,668 & -- \\
\hline 37 & Braley Creek & -- & -- & -- & 3,186 & 379 & 1,041 & -- \\
\hline 38 & Ash Creek & -- & - & -- & 11,261 & 306 & 3,128 & -- \\
\hline
\end{tabular}

${ }^{1}$ Diversions are made upstream from the base-of-mountains station

${ }^{2}$ Includes data for three different base-of-mountains stations

3 Includes data for two different base-of-mountains stations, period of record is water years $1945-84$ for the river-aqueduct station

${ }^{4}$ Period of record is water years $1945-84$ for the ilver-aqueduct station

${ }^{5}$ Well discharge is added to the stream above the river-aqueduct station

${ }^{6}$ Base-of-mountains station is located midway down alluvial fan

${ }^{7}$ Penod of record is water years $1961-72$

${ }^{8}$ Discharge for the river-aqueduct station is a measurement of flow diverted into the Los Angeles Aqueduct and does not include undiverted flow

releasing it to the dual-channel aqueduct system that conveys the water to the Los Angeles area
As shown in table 3, discharge in the river-aqueduct system does not remain constant for the length of the valley 
Table 3 Maxımum, mınımum, and mean annual dıscharge of the Owens Rıver-Los Angeles Aqueduct system and lower Owens River for selected periods of record

[Discharge data from Los Angeles Department of Water and Power (written commun , 1985)]

\begin{tabular}{|c|c|c|c|c|c|}
\hline \multirow{2}{*}{$\begin{array}{l}\text { Site } \\
\text { No } \\
\text { (fig 16) }\end{array}$} & \multirow[t]{2}{*}{ Name } & \multirow{2}{*}{$\begin{array}{c}\text { Period of } \\
\text { record } \\
\text { (water year) }\end{array}$} & \multicolumn{3}{|c|}{ Annual discharge (acre-feet per year) } \\
\hline & & & Maxımum & Minımum & Mean \\
\hline 39 & Owens Ruver at Pleasant Valley Reservoir & $1935-84$ & 444,436 & 165,634 & 271,871 \\
\hline 40 & Owens River at Tinemaha Reservoir & $1935-84$ & 551,184 & 209,067 & 354,537 \\
\hline 41 & Owens Ruver at Charlie's Butte ${ }^{1}$ & $1912-75$ & 543,675 & 126,858 & 282,711 \\
\hline 42 & $\begin{array}{l}\text { Lower Owens River below Los Angeles } \\
\text { Aqueduct intake spill gates }\end{array}$ & $1945-84$ & 107,743 & 0 & 5,156 \\
\hline 43 & Lower Owens Ruver at Keeler Bridge ${ }^{3}$ & $1927-86$ & ${ }^{4} 220,400$ & ${ }^{4} 2,153$ & 17,447 \\
\hline 44 & Los Angeles Aqueduct at Alabama Gates & $1945-84$ & 511,034 & 266,583 & 369,603 \\
\hline 45 & North Haiwee Reservoir & $1945-84$ & $5_{541,060}$ & $5_{285,775}$ & $5_{391,023}$ \\
\hline
\end{tabular}

\footnotetext{
${ }^{1}$ Discontinued in 1975

${ }^{2}$ Discharge to the lower Owens Ruver

${ }^{3}$ Discharge to Owens Lake

${ }^{4}$ Values for water years $1961-84$

${ }^{5}$ Calculated inflow using reservoir storage changes and evaporative losses
}

From Pleasant Valley Reservorr to Haiwee Reservorr, the discharge is contınually altered by gains of water from streams, springs, pumped wells, flowing wells, and the ground-water system as well as by losses of water to irngation and the ground-water system Between Pleasant Valley Reservorr and Tinemaha Reservorr, the Owens River gained a net average of more than 80,000 acre-ft of water during water years 193584 , primarily from diverted streamflow and pumped wells Between Tinemaha and Haiwee Reservours, tributary streams are smaller and more numerous, and there are fewer diversions for agnicultural uses The average net gain of water in this section of the river-aqueduct system was 21,000 acre-ft during water years $1945-84$

Pror to development of the river-aqueduct system, the Owens River was the primary drain of both the surface- and ground-water systems Presently (1988), the river-aqueduct system drains the surface-water system and the Owens River contınues to drain, though to a lesser degree, most parts of the ground-water system A more detalled discussion of the interaction of the surface- and ground-water systems can be found in the section "Water Budget"

\section{Lower Owens Rıver}

Flow in the lower Owens River is measured continuously at Keeler Bridge (fig 16, site 43) Because nearly all water flowing out of Tinemaha Reservorr is diverted into the nver-aqueduct system, most water that reaches Owens Lake (dry) via the Owens River is water that is returned to the river from ditches and undiverted tributary streamflow or ground water that seeps into the river An exception to this occurs durnng extremely wet years when runoff exceeds the capacity of the river-aqueduct system For water years 1938-60, mean annual discharge at Keeler Bridge was about 20,000 acre-ft (D E Willıams, 1969)

\section{Canals and Ditches}

Canals and ditches crisscross the valley, providing water for urrigation, ground-water recharge, and various other uses They range in length from tens of feet to tens of miles and may have partially or completely lined channels Historical records (Inyo Register Newspaper, Feb 12, 1891, from files of Los Angeles Department of Water and Power) indicate that the first ditch in the valley was dug in 1872 , although it is probable that unrecorded ditches were used prior to this date By 1890 , there were about $250 \mathrm{mi}$ of ditches in the valley (Los Angeles Department of Water and Power, written commun, 1988) The original purpose of many of the ditches in the Bishop area was to drain the solls so that the land could be farmed Agricultural activities increased rapidly between 1870 and 1920 and irrigated 
farmlands expanded from about 5,000 to 75,000 acres In 1920 , durıng the peak of farming activity, there was about 24,000 acres of cultivated cropland, whereas about 51,000 acres was flood urrigated and used as pasture (Los Angeles Department of Water and Power, written commun , 1988) In 1978, irrigated farmlands had declined to about 17,000 acres, which was due primarily to purchase of land by the Los Angeles Department of Water and Power and subsequent retirement of land from irrigated use Therefore, during the past hundred years in the valley there has been a general shift in land use from a large consumption of water to less consumption and from a large number of small farms to fewer large farms

Presently (1988), most of the ditches and canals in Owens Valley are used intermittently for purposes of flood control, irrigation, stockwater, recreation, wildlıfe habitats, and spreading of water for recharge The Bishop area has the highest density of canals and ditches in the valley, with many of the larger ones still being operated during much of the year South of Bishop, canals and ditches are concentrated in agricultural areas near the towns of Big Pine and Lone Pine and in the vicinity of Oak Creek near Independence

\section{Water Quality}

The quality of surface water in Owens Valley is generally good and suitable for most uses with appropriate treatment Because the water quality of most surface water in the valley is considered good, only one representative sampling site, located at the gaging station on the riveraqueduct system downstream from the outflow from Tinemaha Reservoir, was used to evaluate temporal changes in water quality The water was sampled at the site as a part of the US Geological Survey's National Stream Quality Accountıng Network (NASQAN) on approxımately a b1-monthly basis from October 1974 through June 1985 Under the NASQAN program, the water was analyzed for chemical and biological constituents The water in the river-aqueduct system has dissolved solids that represent a number of chemical constituents averaging $181 \mathrm{mg} / \mathrm{L}$ and rangıng from 66 to $274 \mathrm{mg} / \mathrm{L}$ (table 4) Sodium, sulfate, calcium, and bicarbonate (inferred from alkalınity) are the principal ions

The water also was analyzed for biological constituents as part of the NASQAN program Phytoplankton were sampled during the warmer growing months from 1974 through 1981 During the last three years of sampling (197981), phytoplankton numbers ranged from 280 cells $/ \mathrm{mL}$ in September 1981 to 42,000 cells $/ \mathrm{mL}$ in March 1981 From March through June and again in September through November (except in September 1980), diatoms were the most abundant organism found in the samples Cyclotella, Stephanodiscus, Melosira, and Asterionella were the most common genera of diatoms present In the summer months a green algae (Dictyosphaerım) and blue-green algae (Anabaena) were the most abundant organisms present in the samples The location of this sampling station, directly downstream from Tinemaha Reservorr, suggests that the phytoplankton found in the samples are more representative of conditions within the reservoir and may be considerably different from conditions in the river itself (S K Sorenson, U S Geological Survey, written commun, 1987) No other phytoplankton data for the Owens River are avallable to compare with these data

The second set of biological analyses were for fecal colıform and fecal streptococci bacteria Fecal colıform bacteria ranged from 1 to 50 colonies per $100 \mathrm{~mL}$ of water, whereas fecal streptococc 1 bactena ranged from 1 to greater than 1,000 colonies per $100 \mathrm{~mL}$ The fecal streptococci bacteria are generally an indicator of livestock activities, rather than human activities There are no published standards for different contaminant levels of fecal streptococci bacteria State standards for fecal colıform bactena (Calıfornı Department of Health Services, 1983), however, establısh 1 colony per $100 \mathrm{~mL}$ as the maxımum level permissible in drinkıng water The river water at the sampling site exceeded these levels for nearly all water sampled Analyses of the bacterial data also indicate that the number of colonies of fecal coliform and fecal streptococci have increased steadily during the peniod of measurement, 1974-85 These analyses from a single station should not be viewed as conclusive evidence that there is a health hazard when using the untreated river water for public supply, but they are an indicator that a hazard may be present and further sampling is needed

\section{Ground Water}

Ground water is used as the main source of water to supplement surface--water runoff used for export and also for public supply and some irrigation uses in the valley Ground water is derived mainly from the valley fill, in contrast, ground water in the bedrock is scarce

Nearly all the recoverable ground water in the valley is in the unconsolidated to moderately consolidated sedimentary deposits and intercalated volcanic flows and pyroclastic rocks that fill the basin Where saturated, these sedimentary deposits and volcanic rocks make up the ground-water system The primary part of the ground-water system, referred to in this report and in the related report that describes numerical evaluation of the hydrologic system (W R Danskın, U S Geological Survey, written commun, 1988) as the "aquifer system," is capable of yielding significant quantities of ground water to wells and to the scrub and meadow plant communities The following discussion describes the hydrogeologic framework of the defined aqu1fer system, the source, occurrence, and movement of water in the system, and the hydraulic characteristics of the hydrogeologic units in the system 
Table 4. Chemical constituents and physıcal propertıes of water in Owens River downstream from Tinemaha Reservoır, water years 1974-85

[ft $3 / \mathrm{s}$, cubic feet per second, $\mu \mathrm{S} / \mathrm{cm}$ at $25^{\circ} \mathrm{C}$, microsiemens per centımeter at $25^{\circ} \mathrm{C}$ Constituent values reported in milligrams per liter]

\begin{tabular}{|c|c|c|c|c|}
\hline $\begin{array}{l}\text { Property } \\
\text { or } \\
\text { constituent }\end{array}$ & $\begin{array}{c}\text { Number } \\
\text { of } \\
\text { samples }\end{array}$ & Mean & $\begin{array}{l}\text { Standard } \\
\text { deviation }\end{array}$ & Range \\
\hline Discharge, instantaneous $\left(\mathrm{ft}^{3} / \mathrm{s}\right)$ & 766 & 4763 & 200 & $5-951$ \\
\hline Specific conductance $\left(\mu \mathrm{S} / \mathrm{cm}\right.$ at $\left.25^{\circ} \mathrm{C}\right)$ & 766 & 295 & 430 & $158-422$ \\
\hline $\mathrm{pH}$, field (units) & 109 & 81 & 05 & $71-96$ \\
\hline Oxygen, dissolved & 73 & 94 & 19 & $70-182$ \\
\hline Hardness, total $\left(\mathrm{CaCO}_{3}\right)$ & 102 & 703 & 138 & $57-106$ \\
\hline Hardness, noncarbonate & 79 & 02 & 14 & $00-12$ \\
\hline Calcium, dissolved (Ca) & 102 & 216 & 41 & $08-32$ \\
\hline Magnesıum, dissolved (Mg) & 101 & 40 & 10 & $9-63$ \\
\hline Sodium, dissolved $(\mathrm{Na})$ & 101 & 319 & 82 & $55-54$ \\
\hline Potassium, dissolved (K) & 102 & 39 & 08 & $18-59$ \\
\hline Alkalınity, field $\left(\mathrm{CaCO}_{3}\right)$ & 89 & 997 & 201 & $39-140$ \\
\hline Sulfate, dissolved $\left(\mathrm{SO}_{4}\right)$ & 100 & 226 & 76 & $5-46$ \\
\hline Chloride, dissolved (Cl) & 102 & 130 & 42 & $42-25$ \\
\hline Fluoride, dissolved (F) . & 102 & 06 & 01 & $04-09$ \\
\hline Silica, dissolved $\left(\mathrm{S}_{1} \mathrm{O}_{2}\right)$ & 102 & 234 & 50 & $13-35$ \\
\hline Solıds, dissolved calculated & 101 & 181 & 371 & $66-274$ \\
\hline Nitrogen, nitrate plus nitrite (as $N$ ) & 81 & 01 & 01 & $00-09$ \\
\hline Phosphorus, total (P) & 101 & 009 & 005 & $003-044$ \\
\hline Arsenic, total recoverable (As) & 30 & 0028 & 0008 & $001-0046$ \\
\hline Barium, total recoverable $(\mathrm{Ba})$ & 17 & 0115 & 012 & $0050-05$ \\
\hline Cadmium, total recoverable (Cd) & 31 & 0005 & 0004 & $00-001$ \\
\hline Chromium, total recoverable $(\mathrm{Cr})$ & 32 & 0006 & 0008 & $00-003$ \\
\hline Cobalt, total recoverable (Co) & 32 & 0019 & 0025 & $00-005$ \\
\hline Copper, total recoverable $(\mathrm{Cu})$ & 32 & 0023 & 0021 & $00-011$ \\
\hline Iron, total recoverable $(\mathrm{Fe})$ & 32 & 07 & 043 & $017-17$ \\
\hline Lead, total recoverable $(\mathrm{Pb})$ & 29 & 0064 & 0052 & $00-02$ \\
\hline Manganese, total recoverable (Mn) & 31 & 0048 & 0038 & $0005-02$ \\
\hline Mercury, total recoverable $(\mathrm{Hg})$ & 28 & 00003 & 00004 & $00-0002$ \\
\hline Selenium, total recoverable (Se) & 31 & 00004 & 00002 & $00-0001$ \\
\hline Silver, total recoverable $(\mathrm{Ag})$ & 23 & 00007 & 00021 & $00-001$ \\
\hline Zinc, total recoverable $(\mathrm{Zn})$ & 30 & 0062 & 0146 & $001-083$ \\
\hline
\end{tabular}

\section{Aquifer System}

The aquifer system is a three-dimensional body of valley fill that is saturated with ground water This saturated volume of valley fill is bounded on all sides by a "boundary surface" (Franke and others, 1987) The boundary surface allows water to either flow in or out of the system, such as at the water table, or acts as a barner to flow, which allows little or no water to enter or leave the system across the boundary surface, such as at a bedrock contact

In Owens Valley the aquifer system is a part of the total ground-water system, it is delineated in figure 17 The upper boundary surface of the aquifer system is the water table and the lower surface is either a bedrock contact, the top of moderately consolidated valley fill, or an arbitrary depth based on the depth of pumped wells The sides of the aquifer system are either bedrock or a part of a lateral boundary surface that allows ground water to flow in or out of the aquifer system, termed a "flow boundary" Thus water can flow laterally in (recharge) or out (discharge) of the aquifer system only through a flow boundary Lateral inflow boundaries include sections along the southeast end of Round Valley, south end of Chalfant Valley, and that part 
of the two valleys overlain by the Volcanic Tableland (figs 11 and 17) Underflow also enters the aquifer system from Bishop and Big Pine Creek drainages and from Waucobı Embayment The lateral outflow boundary of the system is a section that crosses the valley approxımately east-west at the south end of the Alabama Hills Recharge and discharge to the Owens Valley aquifer system occurs also at wells, springs, rivers, and the water table

Hydrogeologıc Framework

The hydrogeologic framework of the aquifer system controls the vertical and horizontal flow of ground water in the system The hydrogeologic framework was simplified into a vertical series of units that represent either groundwater-producing zones or major zones of confinement to vertical flow These units will be referred to as "hydrogeologic units" and are numbered 1 to 3, top to bottom in the aquifer system (pl 2) Saturated valley fill that lies below the defined aquifer system and in contact with the bedrock is referred to as hydrogeologic unit 4 , this unit is not a part of the aquifer system Horizontal segregation of the hydrogeologic units into subunits was done on the basis of previously defined depositional models (fig 14) that describe the lateral depositional patterns The hydraulic characteristics of the hydrogeologic units and subunits represent the conceptualızed framework and control the flow of ground water in the aquifer system

The hydrogeologic units in the aquifer system were divided primarily on the basis of hydraulic criteria rather than strictly geologic or stratıgraphic criteria The hydraulıc criteria were based on either uniform hydraulıc properties or a substantial difference in vertical hydraulic head These two hydraulic criteria were modified from those developed by Weiss and Williamson (1985), who used these criteria to simplify a thick sedimentary sequence located in the Gulf Coastal Plain on a hydraulic basis rather than on a purely stratigraphic and lithologic basis In both the application by Weiss and Williamson (1985) and this study, the main purpose of combinıng and simplifying heterogeneous sedimentary and volcanic subunits on the basis of hydraulic criteria was to be able to simplify and delimit the aquifer system for subsequent three-dimensional ground-water-flow simulation as a part of an evaluation of the hydrologic system (W R Danskın, U S Geological Survey, written commun, 1988)

Briefly, the first criterion used to subdivide the aquifer system is a quasi-three-dimensional method that defines the hydrogeologic units on the basis of uniform hydraulıc properties This method worked well for some parts of the aquifer system but not for most of it The hydrogeologic sections on plate 2 show the hydrogeologic units superimposed on the geologic sections of plate 1 The volcanic rocks of Big Pine volcanic field, the blue and blue-green clays in southern Bishop Basın, and a thin clay bed at about $100 \mathrm{ft}$ below the land surface in the Independence area are examples of valley-fill materials that exhibit uniform hydraulic characteristics These materials can be segregated as a single hydrogeologic unit The bulk of the valley fill, however, is a heterogeneous mixture of different depositional materials that are discontinuous and vertically complex

The second criterion used to define hydrogeologic units was based, on the distribution of vertical hydraulic head The definition of hydrogeologic units becomes more difficult in the thick sequences of valley fill where interfingering and lateral discontınuity cause complex heterogeneity This condition is particularly evident in the alluvial fan, transition zone, and fluvial and lacustrine depositional subunits In many parts of these subunits, hydraulic properties are based on a composite or vertical average of the hydraulic characteristics of the individual deposits, beds, and lenses within the depositional subunit Composite hydraulic characteristics were helpful in delineatıng gross hydrogeologic boundaries The uniformity of the vertical distribution of hydrologic head within a subunit or part of a subunit proved to be the critical criterion used to subdivide large parts of the aquifer system into hydrogeologic units shown on plate 2

The configuration of the water table in Owens Valley, which represents the upper boundary of the aquifer system, is shown in figure 17 Water-level data for this map were compled from more than 500 wells from records of the Los Angeles Department of Water and Power (written commun , 1986) and from data collected from wells drilled coincident with this study The water levels represent the conditions in the valley during spring (March and April) 1984, when pumping for irrigation and export had been farrly constant for several years Sprıng 1984 also represents a wet year, one with above-normal runoff and recharge The period 1981-84 was a series of wet years when pumping was minimal and constant, recharge was high enough to virtually maintain a "full" aquifer system, and ground-water flow through the aquifer system approximated steady-state conditions in which inflow equaled outflow

The water table is the upper surface of the unconfined part of the aquifer system and ranges from the land surface to more than $15 \mathrm{ft}$ below the surface of the valley floor Beneath the alluvial fans along the Sierra Nevada, depths to water can be several hundreds of feet The unconfined part of the aquifer system occurs everywhere throughout the study area and is represented by hydrogeologic unit 1 (fig 17 and pl 2) Hydrogeologic unit 1 consists of interbedded layers of clay, silt, sand, and gravel and contains thin clay layers that may locally confine vertical movement of ground water The vertical hydraulic gradient commonly does not vary more than 1 to $3 \mathrm{ft}$ within the hydrogeologic unit, except for large vertical gradients that are produced along the extreme margins and in localized areas such as beneath tributary streams For most of 


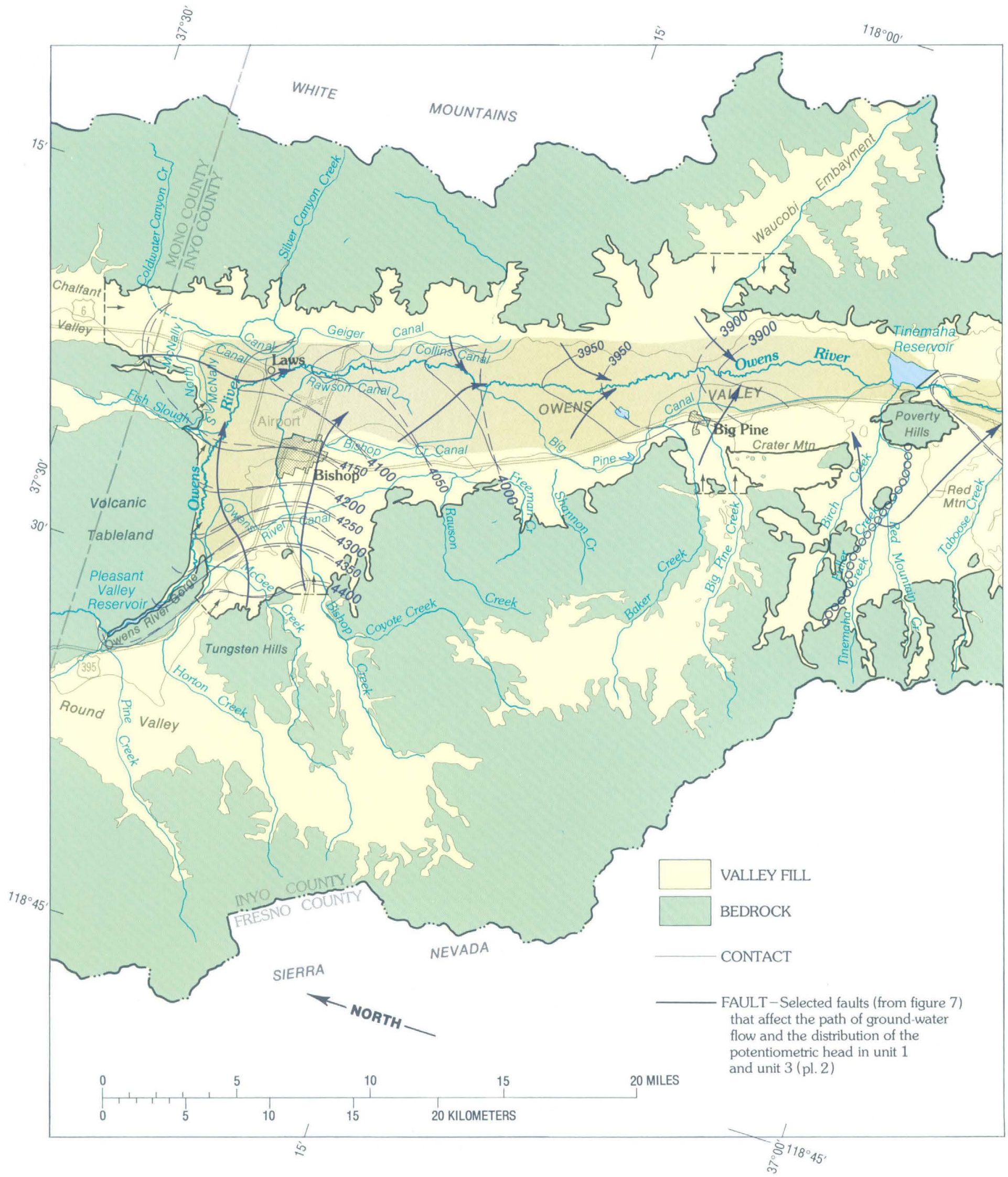

Figure 17. Areal extent of defined aquifer system, occurrence of unconfined and confined conditions, boundary conditions, configuration of potentiometric surface in hydrogeologic units 1 and 3, and direction of ground-water flow, spring 1984. 


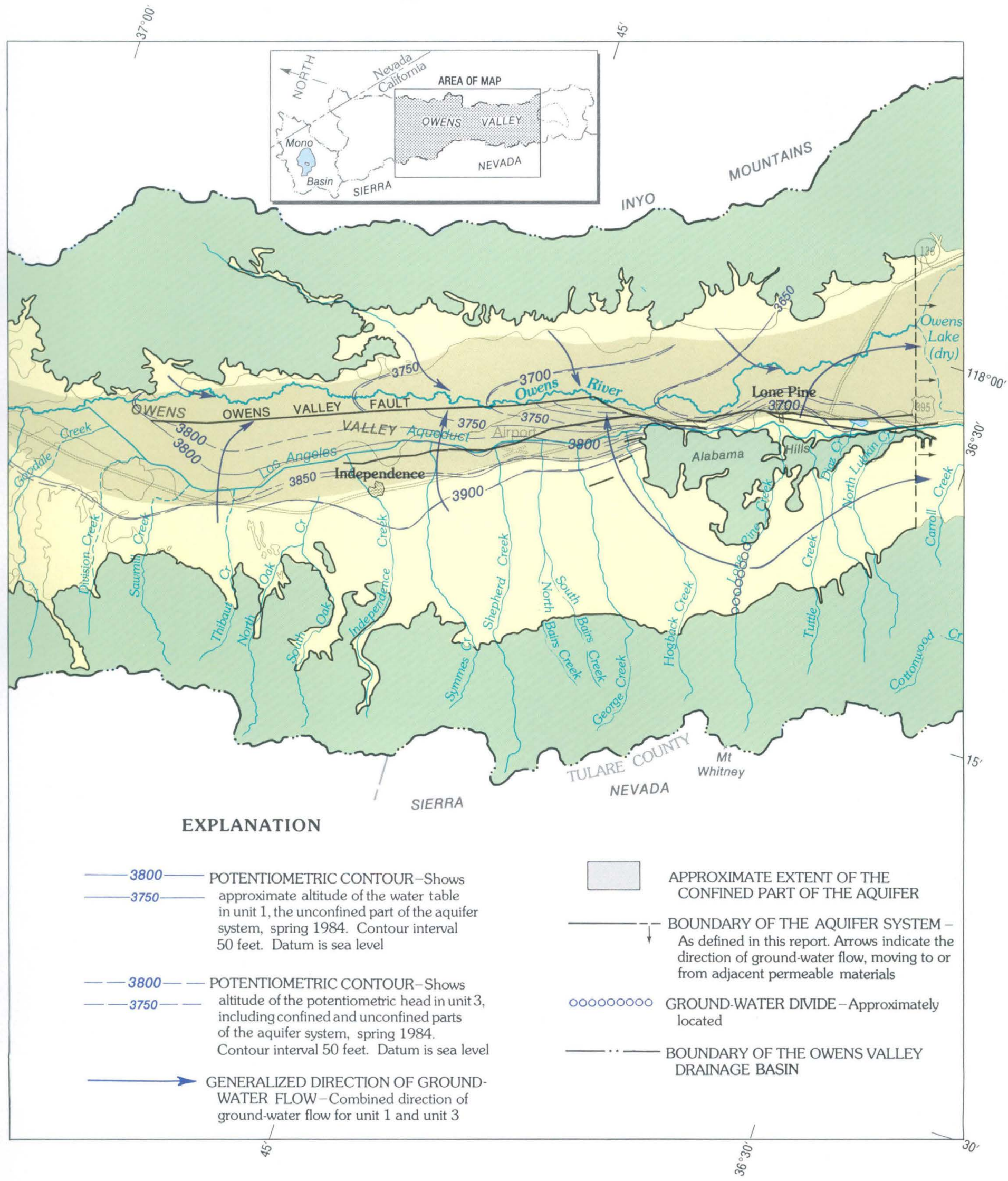

Figure 17. Continued. 
the valley, however, the composite potentiometric head in unit 1 approximates the water-table altitude and for purposes of this report will be assumed to be analogous The saturated thickness of hydrogeologic unit 1 ranges from approxımately $30 \mathrm{ft}$ to as much as $100 \mathrm{ft}$ (fig 17 and $\mathrm{pl}$ 2)

A number of confined zones are present in the aquifer system and have been combined into hydrogeologic unit 3 The confined part of the aquifer system generally extends from the toes of the alluvial fans along the Sierra Nevada to the toes of the alluvial fans along the White and Inyo Mountains and extends along nearly the full length of the valley (fig 17) Confinement is created by a number of lenticular-to-contınuous, flat-lyıng fluvial and lacustrine clay and silty-clay beds Confınement also can be created by fine material deposited by mudflows, which Rachock1 (1981, p 5 and 9) described as a major agent in shaping most alluvial fans These confining beds thin to extınction along the margins of the valley Additional areas of confinement may be formed by the Bishop Tuff and volcanic flows of the Big Pine volcanic field, but an absence of data in these areas prevents a more detalled analysis

Where hydrogeologic units 1 and 3 are in contact, confinement is not significant Both units have nearly the same head ( $\pm 2-3 \mathrm{ft})$, and unconfined conditions are present at the bottom of the aquifer system In this combined hydrogeologic unit (units 1 and 3), unconfined conditions are prevalent north of Laws in Chalfant Valley and in the proximal and medial fan areas along the Sierra Nevada and the White and Inyo Mountains (fig 17 and pl 2)

Hydrogeologic unit 2 is defined as a confining bed and is either a contınuous clay bed or a series of lenticular clay beds thick enough to store ground water that could be released from storage during periods of stressed conditions in the aquifer system (pl 2) The confining beds in unit 2 retard the upward and downward flow of ground water between hydrogeologic units 1 and 3 The quantity of ground water that flows across a confining bed is a function of the thickness of the confining bed, its lateral continuity, the vertical hydraulic conductıvity of the bed, and the hydraulic head at the top and bottom of the confining bed A number of clay beds that lie close together and cover a broad area can form a single confining bed In Owens Valley, this configuration is much more common There are, however, at least two continuous beds of clay that extend for milesfor example, the blue and blue-green clays in the subsurface of the Bishop Basin (fig 12 and pl 1)

The base of the defined aquifer system is the base of hydrogeologic unit 3 and is the bedrock contact in the alluvial fan areas or, in the thick valley-fill sections of the valley, is a depositional contact or an arbitrary depth based on the depth of pumped wells (pl 2) In the Bishop Basin, the base of hydrogeologic unit 3 is the top of an extensively thick and probably moderately consolidated fluvial and lacustrine subunit (hydrogeologic unit 4, pl 2) The base of hydrogeologic unit 3 is defined from vertical electric soundıngs of less than about $30 \mathrm{ohm}$-meters (this study) and from seismic-refraction velocities of greater than 6,500 $\mathrm{ft} / \mathrm{s}$ (Pakiser and others, 1964) The geophysical properties of hydrogeologic unit 4 in the Bishop Basin are similar to those observed in the moderately consolidated deposits (hydrogeologic unit 4) in the Independence area Little is known about the lithology or hydraulic properties of this lower hydrogeologic unit in the Bishop Basin, however, because no wells have penetrated hydrogeologic unit 4 The geophysical contact between hydrogeologic units 3 and 4 probably is hydraulically significant because of a possible abrupt decrease in hydraulic conductıvity The defined base of hydrogeologic unit 3 in the Bishop Basin generally approximates or is deeper than $1 \mathrm{~A}$ tımes the depth of the deepest productive wells in the area

In some parts of the valley fill in the Owens Lake Basin, a subtle depositional contact between the unconsolldated to moderately consolidated valley-fill deposits represents the base of the aquifer system The contact between the unconsolidated and moderately consolidated valley-fill deposits in the Independence area was estımated from drillhole and surface geophysical data This subtle contact between hydrogeologic units 3 and 4 probably represents a decrease in hydraulic conductivity and storage coefficient from the overlying unconsolidated to underlying moderately consolidated sediments The contact is nearly horizontal and is displaced deeper to the east of the normal fault that extends south to north from the Alabama Hills through the Independence area (fig 7 and pl 2, section $E-E^{\prime}$ ) The base is displaced even deeper in the graben east of the Owens Valley fault (pl 2, section $E-E^{\prime}$ )

In areas of the Owens Lake Basin where there is insufficient information to map the top of the moderately consol1dated valley fill and where bedrock is greater than $1,000 \mathrm{ft}$ below land surface, the base of hydrogeologic unit 3 was arbitrarily chosen at $1 \mathrm{~A}$ times the depth of the deepest production wells in the area The arbitrary base was selected to generally minimize the effect of specifying a no-flow boundary condition in the subsequent simulation of the aquifer system This arbitrary base is deep enough below the pumped system that the vertical component of ground-water flow is assumed to be minımal and can be neglected Valley-fill material that lies below hydrogeologic unit 3 and above the bedrock is collectively included in hydrogeologic unit 4

Volcanic rocks are present in hydrogeologic units 1, 2, and 3 The volcanic rock subunit can usually be differentiated from the depositional subunits by the distinct geologic definition of the upper and lower surfaces of the subunit Volcanic rocks included as a part of the valley fill generally represent permeable aquifer material Volcanic flows, however, can be very anisotropic Flows, particularly the brecciated tops and bottoms of layered aa flows, have extremely high horizontal hydraulic conductıvities (table 1), whereas the vertical hydraulic conductivities of layered flows, because of the dense crystallıne inner cores, can be extremely low, thus retarding 
vertical movement of ground water The degree of retardation is a function of how fractured the inner core is Thus, unfractured to moderately fractured flows can act as confinıng beds in the aquifer system To some extent this confining effect is evident in the Poverty Hills-Big Pine area, where volcanic rocks have been included in hydrogeologic unit 2 (pl 2, sections $C-C^{\prime}$ and $D-D^{\prime}$ )

Source, Occurrence, and Movement of Ground Water

Virtually all the ground water in the Owens Valley aquifer system is derived from precipitation that falls within the Owens Valley drainage basin area Deep infiltration (recharge) occurs primarily through the alluvial fans as water runs off the Sierra Nevada as a result of snowmelt or ranfall Most of the runoff infiltrates through the heads of the alluvial fans and through the tributary stream channels Lesser quant1ties of recharge result from infiltration of water in canals and ditches primarily on the valley floor, through the volcanic rocks, from runoff in bedrock areas withın the valley fill (for example the Poverty and Alabama Hills), by leakage from the river-aqueduct system, and by underflow from Chalfant and Round Valleys Underflow to the Bishop Basin from Chalfant Valley also includes water moving south from Hammil and Benton Valleys Most of the ground water from Chalfant, Hammil, and Benton Valleys enters the Bishop Basin near Fish Slough beneath the southeastern part of the Volcanic Tableland Recharge to the aquifer system is minimal from percolation of water that moves through bedrock fractures to the zone of saturation or, because of the high evapotranspiration, from water that percolates directly to the water table from rainfall on the valley floor

Ground water moves along permeable zones from areas of higher hydraulıc head to areas of lower hydraulıc head The direction of ground-water flow is approximately perpendicular to lines of equal hydrologic head The areal pattern of ground-water flow in the valley is shown in figure 17 , and the vertical flow directions in hydrogeologic units 1,2 , and 3 are shown on plate 2 The Darcian rate of flow along the illustrated flow paths is determined by the hydraulıc gradient, the hydraulic conductivity, and the crosssectional area of flow Typical rates in the valley range from less than a foot per year in clay and silt to hundreds of feet per year in the more permeable basalt Rates of horlzontal flow of water in hydrogeologic units 1 and 3 generally range from 50 to $200 \mathrm{ft} / \mathrm{yr}$

Ground water flows from areas of recharge to areas of discharge Discharge can be from springs, wells, evapotranspiration, or gains to the Owens Riveı In general, ground-water flow is from the margins of the valley, mainly the west margin, toward the center of the valley and then south toward Owens Lake (fig 17) As ground water flows downgradient to the toes of the alluvial fans and the transition zones, the flow is primarily horizontal rather than ver- tical (pl 2) This horizontal flow of ground water is split by the confining beds of hydrogeologic unit 2 that interfinger with the alluvial fans and the transition zone and direct the flow of water into hydrogeologic units 1 and 3 (fig 17 and pl 2) Discharge from hydrogeologic unit 3 is generally upward through hydrogeologic unit 2 to unit 1 , from wells, or through the valley fill to the south end of the valley

Ground water that originates as underflow from Round and Chalfant Valleys enters hydrogeologic unit 3 in the Bishop Basin This water mixes with water recharged along the toes of the alluvial fans and through the volcanic rocks and moves south along the valley toward the "narrows" (fig 11) Discharge from hydrogeologic unit 3 is primarily to wells, upward to hydrogeologic unit 1 , or underflow south to Owens Lake Basın through the "narrows", whereas discharge from hydrogeologic unit 1 is principally to evapotranspiration and wells

Water that enters the aquifer system in the Owens Lake Basin as underflow through the "narrows" or as recharge through the alluvial fans moves south to Owens Lake (dry) Ground water in hydrogeologic unit 3 discharges to wells or upward to hydrogeologic unit 1 Water in hydrogeologic unit 1 discharges primarily by evapotranspiration and wells, and a lesser amount to springs and as base flow to the lower Owens River What happens, however, to ground water that flows to the south end of the ground-water system at Owens Lake (dry) is not known with certainty The bulk of the ground water probably flows vertically upward and is discharged as evaporation from the dry lake Minor quantities of water may flow at depth through the fractured bedrock beneath Haiwee Reservoir to Rose Valley, located south of Owens Valley

\section{Hydraulic Characterıstıcs of the Hydrogeologıc Unıts}

The hydraulic characteristics-saturated thickness, horizontal and vertical hydraulic conductivities, transmissivity, specific yield, and storage coefficient-were estımated from pumped-well and aquifer tests, drill-hole data, and geophysical data

The vertical movement of water from hydrogeologic unit 3 to unit 1 is one of the principal sources of water in unit 1 The recharge of hydrogeologic unit 1 is of particular impor-tance in Owens Valley because of transpiration demand exerted by the alkalıne scrub and meadow commun ties on soil moisture derived from the shallow water table (Dileanıs and Groeneveld, 1989, Sorenson and others, 1989, Duell, 1990) Vertical hydraulic conductivity in combination with the differ-ence in hydraulic head between two hydrogeologic units deter-mines the rate of water movement from one hydrogeologic unit to another The vertical hydraulic conductivities in the Owens Valley aquifer system are the least well known of the hydraulic characteristics (Danskın, 1988) 
Three methods are typically used to determine vert1cal hydraulic conductivity First, laboratory measurements can be used to determine the vertical hydraulic conductivity of core samples taken from the aquifer system Second, aquifer tests, which yield field estımates of vertical hydraulic conductivity, can be conducted Third, a ground-waterflow model can be used to estımate vertıcal hydraulic conductivity by using a method of trial and adjustment to match histoncal hydraulic heads in hydrogeologic units 1 and 3 Prelıminary ground-water-flow models of the Owens Valley aquifer system were initially used to evaluate the distribution of hydraulic characterıstics (Yen, 1985, Danskın, 1988) Danskın (1988) noted, in partıcular, that further studies were needed to quantıfy vertical hydraulıc conductivities In this study, multiple-well aquifer tests were used to record the response of the aquifer system and these results were then simulated in detalled cross-sectional groundwater-flow models in order to test and refine the estimates of hydraulic characteristics, partıcularly vertical hydraulic conductivities The analysis of these tests is described more fully by W R Danskın (U S Geological Survey, written commun , 1988)

Well-efficiency and some aquifer tests were conducted using Los Angeles Department of Water and Power production wells and the wells drilled for this study Many of the department's production wells in the valley, however, are perforated in both hydrogeologic units 1 and 3 and therefore present some problems for use in aquifer tests designed to characterize the hydraulic properties of each specific hydrogeologic unit As a part of this study, 20 wells were drilled and left open to specific units to determine the hydrologic characteristics of hydrogeologic units 1 and 3 The shallow wells fully penetrated hydrogeologic unit 1 Deep wells were installed at 10 of the sites The deep wells were perforated only in hydrogeologic unit 3 and were isolated from unit 1 by bentonite seals that were set opposite confinıng beds of hydrogeologic unit 2

Many of the department's production wells used for the tests are located in one of the nıne well fields (fig 18) Therefore, the distribution of field-determined values of the aquifer hydraulic characteristics are concentrated in small areas near the well fields A slightly more uniform coverage of the aquifer system was achieved using wells installed as a part of this study (fig 18) Even so, hydraulic characteristıcs for large parts of the aquifer system are still lackıng, particularly between Bishop and Big Pine, along the center of the valley and east of the Owens River in the Owens Lake Basın, east of Lone Pıne, and along the alluvial fans

Because the spatial distribution of the aquifer hydraulic characteristics in the valley is limited, characteristics derived from isolated field tests had to be extrapolated to broad areas One method to extend hydraulic data to parts of the valley fill where there is little or no hydraulic information involves using generalızed relations between types of depositional conditions or lithology and values of hy- draulic conductivity and storage coefficient (Davis, 1969, Freeze and Cherry, 1979, Lohman, 1979) This approach, although valid if other data are absent, generally yields a much broader range of values than would be estımated or determined from elther aquifer tests or model calıbration Published values for hydraulic characteristics were modified and used as background information to develop table 1 These values were then modified to fit conditions prevalent in Owens Valley on the basis of well-efficiency tests, aquifer tests, and calıbration of cross-sectional and areal groundwater-flow models

\section{Unıt 1 Characterıstıcs}

Horizontal hydraulic characteristics of hydrogeologic unit 1 commonly change in a systematic fashion that is related to the depositional models discussed previously (fig 14) The principal patterns of deposition in the valley fill are etther fluvial and lacustrne or alluvial fan The alluvial fan deposits generally are more poorly sorted and have a broader range of sedıment grain sıze than the fluvial and lacustrine sedıments Consequently, the alluvial fan deposits have a lower hydraulıc conductivity and specific yield The transition zone that is located between the two depositional subunits and overlain by younger alluvial fan deposits represents a zone with higher values of hydraulic conductivity and specific yield than either the alluvial fan or fluvial and lacustrine sediments These higher values result because the transition zone materials are better sorted and are entirely coarse sand and gravel, derived from the accumulation of beach, bar, and river-channel deposits Sections that illustrate the relation between the fluvial and lacustrine and alluvial fan subunits and the buried transition zone are shown on plate 2

Hydrogeologic unit 1 generally consists of a highly complex mixture of different size lenses or beds of fine and coarse sedıment and, to a lesser extent, interlayered volcanic rocks The texture of the sediment combined with the arrangement of the lenses of sediment and rocks determines the composite hydraulic characteristics of the hydrogeologic unit The textural fabric, the axial arrangement of individual, elongate, or platy grains, and the lenses of the fine or coarse sediment tend to be horizontal in the valley fill This horizontal orientation creates a ground-water-flow component that is dominantly horizontal within each subunit Ranges of hydraulic-characteristics values for the various subunits are shown in table 1

The vertical flow of ground water is controlled by the textural fabric and the extent and distribution of lenses or beds of volcanic rock or fine or coarse sediment in the vertical section Ground water that flows vertically across the textural fabric is retarded severely in relation to horizontal flow Flow is further retarded by low-hydraulic-conductivity lenses and beds in the section When the vertical arrangement of rock or fine and coarse sediment lenses or beds are randomly or 


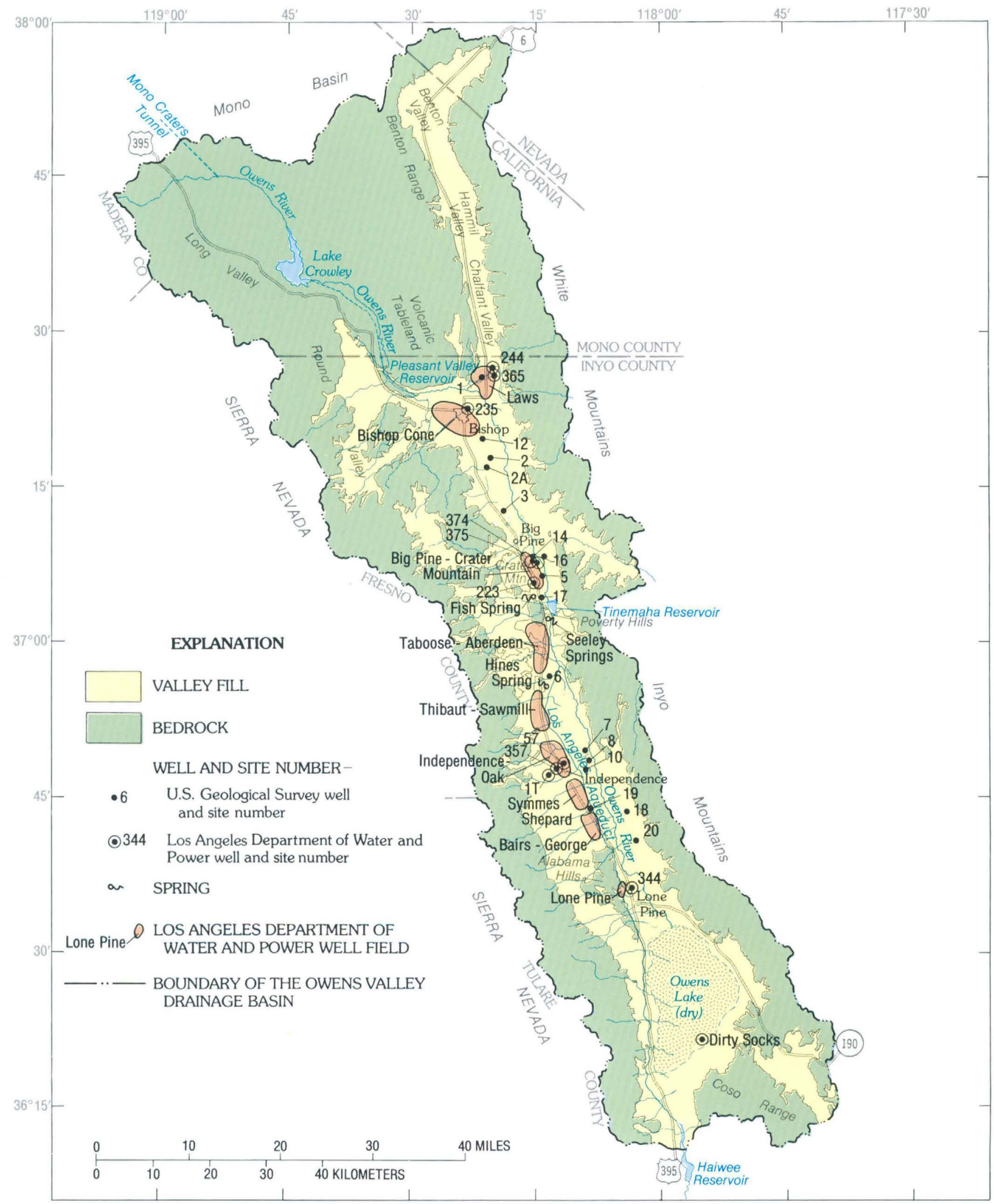

Figure 18. Location of selected wells and springs sampled for water quality or used for analysis of aquifer characteristics, and approximate area of the Los Angeles Department of Water and Power well fields. 
nonuniformly distributed, or a particular lens of sand or clay is less likely to occur than the other, the vertical hydraulic conductivity can be mathematically averaged This average represents a composite vertical hydraulic conductivity value for the hydrogeologic unit When, however, a significant thickness of rock or clay is present in the vertical section, the retardation effect on vertical flow is controlled to a greater extent by the hydraulic conductivity of the individual lens or bed The composite vertical hydraulic conductivity of the unit is no longer computed as a simple mathematical average, the lower hydraulic conductıvity of dominant lenses or beds must be geometrically averaged on the basis of individual hydraulic conductivities, lens or bed thickness, and vertical position in the section Typically in the valley fill, the lenses or beds of fine and coarse sediment in hydrogeologic unit 1 are randomly onented, and a simple mathematical average of vertical hydraulic conductivities suffices as the composite value

Several aquifer tests were conducted in hydrogeologic unit 1 as a part of these studies The hydraulic conductivittes and specific yields estımated from these tests generally represent the average composite values for the specific subunit Water-level-response data collected from observation wells during aquifer tests indicate that hydrogeologic unit 1 of the aquifer system responded to delayed gravity drainage Data obtained from a test conducted in the fluvial and lacustrine sediment or subunit of hydrogeologic unit 1 were analyzed by using the method described by Neuman (1975) This technique enables the calculation of the ratio of vertical hydraulic conductivity to horizontal hydraulic conductivity for the unconfined zone, often referred to as the anisotropy ratio The horizontal hydraulic conductivity was found to be about 15 tumes greater than the vertical hydraulic conductivity in the fluvial and lacustrine subunit, with an anisotropy ratıo of 0066

Horizontal hydraulic conductivities determined for the fluvial and lacustrine subunit of hydrogeologic unit 1 from aquifer tests ranged from 11 to $59 \mathrm{ft} / \mathrm{d}$ Specific yields for the subunit ranged from about 0002 to 0042 These specific yield values are too low and not representative of actual values because the tests were not of long enough duration Delayed gravity drainage still controlled the test response, and a late tıme-equilibrium condition was not achieved More reasonable specific yields would range from 010 to 015 for the variable fluvial and lacustrine deposits No tests have been conducted in the alluvial fan deposits of hydrogeologic unit 1 , but hydraulic conductivity and specific yield should be lower than for the fluvial and lacustrine deposits because the deposits are more poorly sorted Also, hydraulic conductivities and specific yield of volcanic rocks, although included in part of hydrogeologic unit 1 , are discussed separately because of their unique characteristics

In parts of the aquifer system, hydrogeologic unit 1 is partially confined or leaky An example of leaky conditions is found in the Independence area where specific yields were much lower than those observed in other parts of unit 1 and calculated transmissivities increased with distance from the pumped well Geophysical and drillers' logs indicate that overlapping and interlayered clay lenses are present throughout unit 1 in the Independence area and that hydrogeologic unit 1 is separated from similar materials in hydrogeologic unit 3 by a 15 -foot-thick tight and sticky clay $A$ 43-hour-long, constant-discharge test was conducted in the area by using a pumped well and four observation wells at USGS 8 (fig 18) The observation wells were located radially about the pumped well at various distances, and all wells were perforated in the same 50-foot interval at the top of hydrogeologic unit 1 Although the total thickness of hydrogeologic unit 1 in this area was estimated to be approximately $90 \mathrm{ft}$, potential effects of partıally penetratıng wells were determined not to be significant

Drawdown response in the observation wells at USGS 8 yielded calculated transmissivities that increased with radial distance from the pumped well The apparent increase in transmissivity with distance for observation wells at greater distance from the pumped well indicates a contribution or leakage of water to the drawdown cone other than from the aquifer material surrounding the well Recharge from canals, ditches, or the river and aqueduct system was discounted because of their distance from the test site Return-flow infiltration from the discharge water from the pumped well also was discounted because it was removed from the site by a pipe The most likely explanation was upward leakage of water from the moderately confined layers withın hydrogeologic unit 1 that had a slightly higher hydraulic head ( 1 to $3 \mathrm{ft}$ ) than the water table or from hydrogeologic unit 3 that had a much higher hydraulic head ( $33 \mathrm{ft}$ ) than the water table The leaky conditions observed at USGS 8 probably are typical of most parts of the valley where hydrogeologic unit 1 includes fluvial and lacustrine deposits

The greatest hydraulic conductivity of the saturated, buried olıvine basalt flows occurs in breccia and clinker zones that form at the top and bottom of the flows The dense centers of flows are less permeable than the interflow breccia and clinker zones As a result, water is channeled parallel to the plane of layered basalt flows much more easily than vert1cally between flows However, vertical fractures that occurred after the flows had cooled might enable water to move vert1cally from one permeable zone to another This interconnection of flowpaths can create a confusing distribution of hydraulic heads and, when wells are being pumped, can generate both confined and unconfined responses over short distances Therefore, aquifer tests conducted in the basaltic rocks of Owens Valley present unique problems, simılar to those found in tests of saturated fractured rock For example, at some well sites in Owens Valley, discharge rates high enough to induce drawdown, even in observation wells close to the pumped well, are difficult to attain Because of the extremely high transmissivities of these saturated rocks, dynamic equilibrium is attained within minutes and, consequently very little drawdown data can be obtained Natural hydraulic conductıvities of olivine basalt estımated from aquifer tests average about 
$1,200 \mathrm{ft} / \mathrm{d}$ and range from 400 to $12,000 \mathrm{ft} / \mathrm{d}$ Actual transmissivities in the basalt flows are generally greater than 1 million $\mathrm{ft}^{2} / \mathrm{d}$ as a result of fracturing created by drilling techniques and use of explosives in the well bore

An interesting hydrologic phenomenon has been observed in wells that tap the volcanic flows of the Los Angeles Department of Water and Power well field at Big Pine (fig 18) Aquifer tests conducted in the well field using production wells located at the south end of Crater Mountain (fig 18) created drawdown in a well $32 \mathrm{mi}$ north after the pumped well was shut down This well response indicated that a pressure transient was transmitted along predominant volcanic flows and fractures to other parts of the well field $(\mathrm{M} \mathrm{L}$ Blevins, Los Angeles Department of Water and Power, written commun , 1986)

Unıt 2 Characterıstıcs

Whether hydrogeologic unit 2 is represented by a un1form and massive clay bed, such as the blue and blue-green clays near Big Pine (fig 12), or overlapping lenses or beds of clay typical in the valley fill, the vertical hydraulic conductivity and specific storage were estimated using one of three methods The first two methods use aquifer-test data collected in hydrogeologic units 1 and 3 The first method is described by Hantush (1960) for the calculation of transmissivity and storage coefficient of a leaky, confined aquifer and accounts for water diverted from storage within a confining bed or beds The transmissivity then was divided by bed thickness to determine hydraulic conductivity The second method is referred to as the ratio method (Neuman and Witherspoon, 1971) and uses the ratio of drawdowns in the confining bed(s) and aquifer(s) to calculate the hydraulic conductivities of the confinıng bed(s) The third method estımates vertıcal hydraulic conductivity through calibration of distributed-parameter, ground-water-flow models, both areal three-dimensional and cross-sectional The use of models in the numerical analysis of the hydrologic system is discussed more fully by W R Danskın (U S Geological Survey, written commun , 1988)

On the basis of these methods, the vertical hydraulic conductivity of hydrogeologic unit 2 was estimated to range from $0002 \mathrm{ft} / \mathrm{d}$ for poorly sorted deposits of clay with gravel to $000083 \mathrm{ft} / \mathrm{d}$ in the massive blue-green clay beds Field data were not sufficient to estımate specific storage, so values derived by Neuman and Witherspoon (1971) for similar sediments were used and tested using ground-water-flow models The specific storage of clay used in this study is about 000024 Vertical hydraulic conductivity and storage values were not estımated for the volcanic rock subunit from field data because of the paucity of data Instead, inter-active calıbration of prelimınary and cross-sectional ground-water-flow models were used to estımate vertıcal hydraulıc conductıvity and storage of the volcanic rocks in hydrogeologic unit 2 (W R Danskın, U S Geological Survey, written commun , 1988)
Unıt 3 Characterıstıcs

Hydrogeologic unit 3 is a composite of many confined alluvial fan and fluvial and lacustrine beds and some interlayered olıvine basalt and layers of Bishop Tuff Unit 3 represents the most heavily pumped part of the aquifer system in the valley More than 100 production wells distributed among nıne well fields (fig 18) withdraw water from this hydrogeologic unit The predominant horizontal layering of sedımentary beds, lenses, and textural fabric in hydrogeologic unit 3 is similar to that of hydrogeologic unit 1 The distribution of small lenses and beds of fine and coarse sediment is random or nonuniform in hydrogeologic unit 3 as in unit 1 However, the relatively high horizontal hydraulic conductivities of the interconnected and interlayered lenses and beds of sediment create a nearly uniform distribution of hydraulic head in hydrogeologic unit 3 This uniform distribution of head enables hydrogeologic unit 3 to be conceptualized as a single unit of similar transmissivity and storage coefficient As in hydrogeologic unit 1, the lateral changes in hydraulic characteristics can be estimated over broad areas by assigning hydraulic characteristics to particular depositional or rock subunits on the basis of the depositional models (fig 14)

Because many of the Los Angeles Department of Water and Power production wells in the valley are open to both hydrogeologic units 1 and 3, many of the aquifer tests involving these wells were difficult to interpret Responses in observation wells often could not be attributed to stress in hydrogeo$\operatorname{logic}$ units 1 or 3 only Therefore, many of the aquifer tests in hydrogeologic unit 3 were conducted using wells drilled as a part of this cooperative study and perforated in limited parts of the subunit Constant-discharge tests were conducted, generally lastıng 48 hours or less, to estımate the hydraulıc characteristics of hydrogeologic unit 3 Hydraulic characteristics from these tests then were used to aid in interpretıng single and multiple well tests in the Los Angeles Department of Water and Power well fields (fig 18) using small-scale, crosssectıonal, ground-water-flow models (W R Danskın, US Geological Survey, written commun , 1988) On the basis of the results from the tests and models, horizontal hydraulic conductivity was estımated to range from 12 to $150 \mathrm{ft} / \mathrm{d}$, and the storage coefficient ranged from 00001 to 000044 for fluvial and lacustrine deposits in hydrogeologic unit 3

Results of aquifer tests in hydrogeologic unit 3 indicate that the clay members that confine the unit may contribute water taken from storage In two observation wells, drawdown response due to pumping was compared to time divided by the square of the radial distance from the pumped well $\left(t / r^{2}\right)$ (fig 19) This test was conducted in wells that penetrate hydrogeologic unit 3 below the blue-green clay that composes hydrogeologic unit 2 in the Big Pine area (fig 12 and pl 2, section $C-C^{\prime}$ ) The wells are located $1 \mathrm{ml}$ south of Big Pine at USGS site 14 (fig 18) As described for a test in hydrogeologic unit 1 , the vertical shift in waterlevel response caused by pumping for the two observation 
wells indicates an extra contribution of water In this case, hydrogeologic unit 3 is characterized by a lower head than is hydrogeologic unit 1 Because of the short duration of the test ( 22 hours), it is not likely that water moved from hydrogeologic unit 1 to unit 3 through the thick blue-green clay confining bed of unit 2 , nor is it likely that water moved up from unit 4 The most likely explanation is that water was released from storage in the 90 -foot-thick blue-green clay In a plot that considers water derived from storage in confining beds (fig 20), the log-log plot of drawdown and tıme for an observation well located $1,000 \mathrm{ft}$ from the pumped well was superimposed on type curves developed by Hantush (1960) for leaky confined aquifers Curve matching with the Hantush-type curve $(\beta=005)$ yielded a transmissivity of $11,700 \mathrm{ft}^{2} / \mathrm{d}$ and a storage coefficient of 000045 for the fluvial and lacustrine subunit in hydrogeologic unit 3 Differences between data and the type curve during the first 10 minutes of test are believed to be caused by vanations in the initial pumping rate

The choice of match points is subjective and may vary slightly from one worker to another However, when storage from confining beds is suspected, the use of Hantush's (1960) leaky artesian curves rather than the standard Theis (1935) non-leaky curve is indicated Using a saturated thickness of about $180 \mathrm{ft}$ in the area near USGS site 14 , the perforated interval below the clay, horizontal hydraulic conductıvity in hydrogeologic unit 3 was estimated to be about $60 \mathrm{ft} / \mathrm{d}$ This value agrees well with other tests conducted in Owens Valley in similar deposits of hydrogeologic unit 3 of moderately to well-sorted fluvial deposits, fine gravels, and fine to coarse sands

\section{Faults}

In addition to anisotropic conditions created by vertical and lateral lithologic changes in the aquifer materials, faults create abrupt lateral changes in hydraulic charactenstics Evidence of faults that cut the valley fill is well demonstrated in the valley by offsets in topography, alignment of volcanic cones, dense linear communities of scrub and meadow plants, lines of springs (W T Lee, 1906), or abrupt changes in hydraulic head (fig 17) Many of the faults that create these features are onented north-south and are generally onented perpendicular to the dominant ground-water flow path onginating in recharge areas along the west margin of the valley An interesting feature associated with these faults is their ability to deflect or retard ground-water flow (D E Williams, 1970)

The retarding effect of faults can vary from nearly impermeable barners to ground-water flow to farly permeable features with a minımal retarding effect The waterretarding effect of a fault or fault zone is generally the result of (1) the alteration of valley-fill texture by compaction and extreme deformation created along the fault due to squeezıng, stretchıng, and slıppıng, (2) drag-foldıng of water- bearing strata immediately adjacent to the faults that can distort layered sediments to the extent of becoming virtually parallel to the fault, (3) the juxtaposition of pervious material opposite impervious material, and (4) partial cementation of the sediments near the fault produced by precipitation of calcium carbonate as carbon dioxide degasses from ground water deflected upward along the fault All these processes, in combination or alone, affect the hydraulic conductivity of the valley fill near faults Similar groundwater-retardation effects have been observed along faults in the Mojave Desert region of southeast Calıfornia (J S Bader, U S Geological Survey, written commun, 1987)

The Owens Valley fault, which bisects the northern part of the Owens Lake Basin (fig 7), has offset clay and sand-gravel lenses and beds and creates a significant barner to ground water that flows from west to east (fig 17) On the basis of a number of vertical electric soundings that define an east-west section through Independence (pl 1,

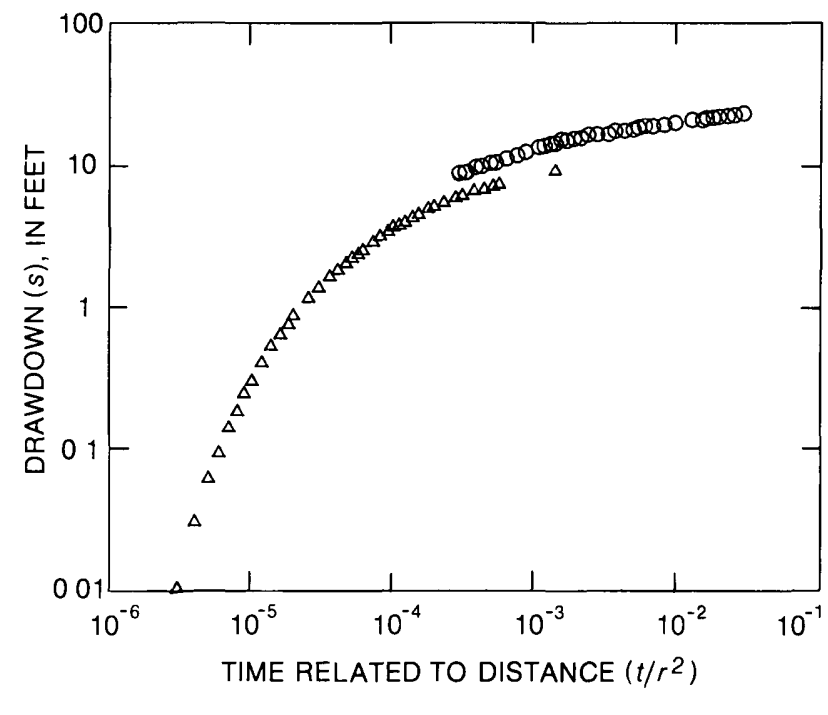

EXPLANATION

OBSERVATION WELLS

- U S Geological Survey well 14 at radius 135 feet

$\Delta \quad$ Los Angeles Department of Water and Power well 375 at radius 1,000 feet

PUMPED WELL

Los Angeles Department of Water and Power well 374 Constant discharge is 2,055 gallons per mınute

DATE OF TEST

May $29-30,1986$

$t-$ TIME, IN MINUTES SINCE PUMPING BEGAN

$r$-DISTANCE, IN FEET FROM OBSERVATION WELL TO PUMPING WELL

Figure 19. Logarithmic plot of drawdown compared to $t / r^{2}$ for two observation wells (see fig 18 for location) south of Big Pine 
section $E-E^{\prime}$ ), lacustrine-clay layers are vertically offset and drag-folded along the fault These clay layers lie juxtaposed with fluvial sand and gravel on each side of the fault Drillers' logs and water levels from wells located east and west of the fault support the interpretation of a significant groundwater barrier Water levels in wells on opposite sides of the fault differ by as much as $50 \mathrm{ft}$ in hydrogeologic unit 3 These differences indicate limited transmission of ground water across the fault The water-retarding effect of the Owens Valley fault extends from just north of the Alabama Hills to just south of the Poverty Hills (figs 7 and 17)

Other faults in the Bishop and Owens Lake Basins also create a water-retarding effect to ground-water flow Fault disruption of the layered valley-fill sedıments has been noted along the fault that traces the east margin of the Alabama Hills and continues north through the Independence area to Poverty Hills (figs 7, 11, and 17) This fault is a less effective barner to ground-water flow than the Owens Valley fault, but it does retard ground-water flow, produce springs, and create boundary effects and distorted cones of depression near pumped wells

\section{Water Quality}

The chemical analyses of ground water from eight wells in the valley indicate a fairly small range of concentrations for dissolved constituents with exception of the well named "Dirty Socks" (table 5) The Dirty Socks well is located at the extreme south end of the valley (fig 18) in the highly salıne lacustrine clays of Owens Lake (dry) On the basis of the major-1on chemistry of the water from all the wells except Dirty Socks, one chemical type was prevalent - a calcium bicarbonate water Water from the Dirty Socks well is a sodium chloride bicarbonate type

The classification of the water is illustrated in a trilinear diagram (fig 21). All the values for the well water used for domestic or irrigation purposes fall within the calcium bicarbonate section of the diagram The same water had

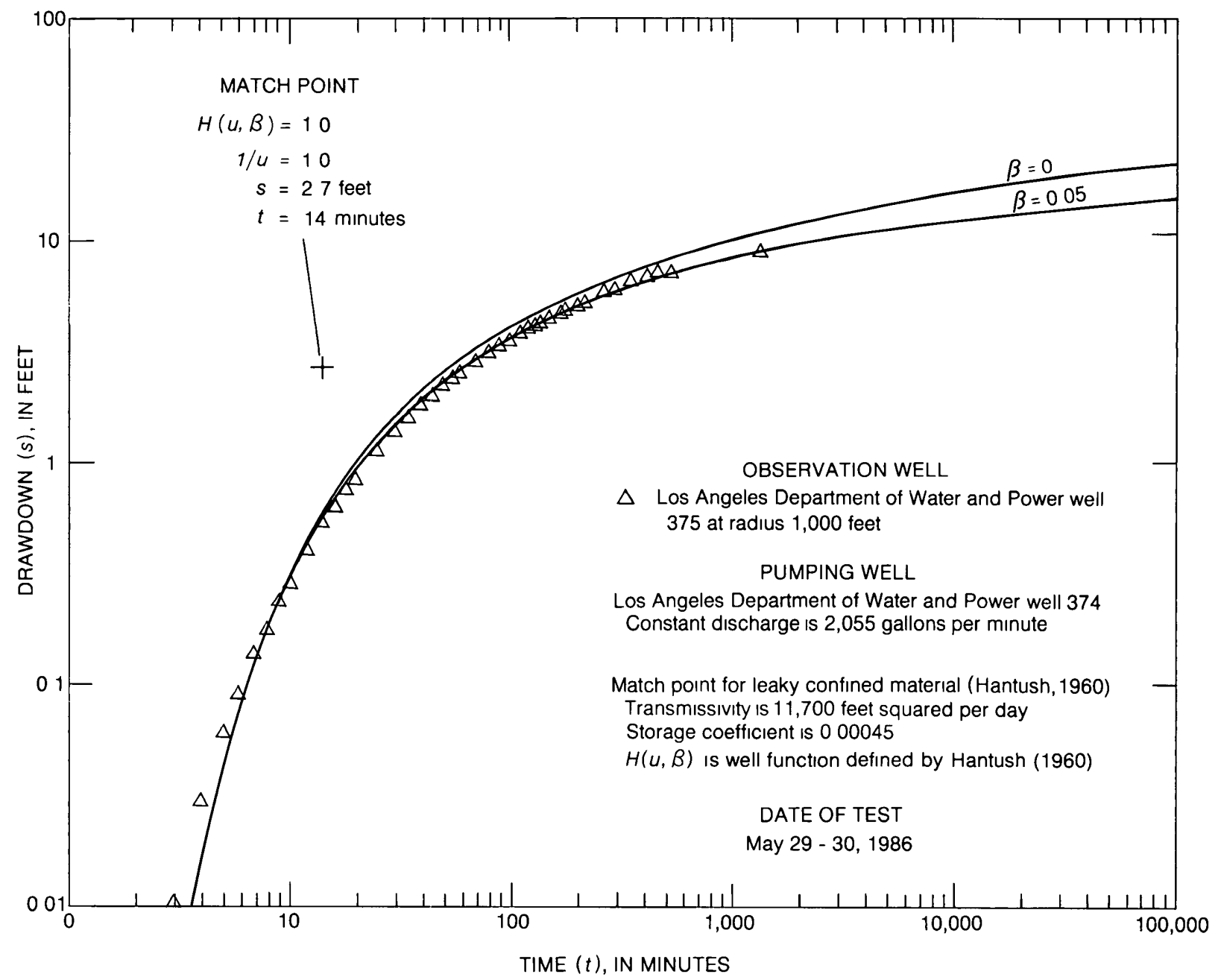

Figure 20. Logarithmic plot of drawdown compared to tıme for an observatıon well (see fig 18 for locatıon) south of Big Pıne usıng match point for leaky confıned materıal 
Table 5. Chemical analyses of water from selected wells in Owens Valley

[Values in milligrams per liter, except specific conductance in microsiemens per centımeter at $25^{\circ} \mathrm{C}, \mathrm{pH}$ in units, temperature in degrees Celsius, and sodium-adsorption ratio --, no data]

\begin{tabular}{|c|c|c|c|c|c|c|c|c|c|c|c|}
\hline $\begin{array}{c}\text { Well } \\
\text { number } \\
\text { or name } \\
\text { (fig 18) }\end{array}$ & $\begin{array}{l}\text { Date } \\
\text { of } \\
\text { sample }\end{array}$ & $\begin{array}{l}\text { Spe- } \\
\text { cific } \\
\text { conduc- } \\
\text { tance }\end{array}$ & $\begin{array}{l}\mathrm{pH} \\
\text { field }\end{array}$ & $\begin{array}{l}\text { Tem- } \\
\text { pera- } \\
\text { ture }\end{array}$ & $\begin{array}{c}\text { Hard- } \\
\text { ness } \\
\text { (as } \\
\left.\mathrm{CaCO}_{3}\right)\end{array}$ & $\begin{array}{l}\text { Cal- } \\
\text { clum } \\
\text { (Ca) }\end{array}$ & $\begin{array}{c}\text { Magne- } \\
\text { slum } \\
\text { (Mg) }\end{array}$ & $\begin{array}{l}\text { Sodı- } \\
\text { um } \\
(\mathrm{Na})\end{array}$ & $\begin{array}{l}\text { Potas- } \\
\text { sium } \\
(\mathrm{K})\end{array}$ & $\begin{array}{l}\text { Sodium } \\
\text { adsorp- } \\
\text { tron } \\
\text { ratio } \\
\text { (SAR) }\end{array}$ & $\begin{array}{c}\text { Alka- } \\
\text { linity } \\
\text { (as } \\
\left.\mathrm{CaCO}_{3}\right)\end{array}$ \\
\hline Dirty Socks & $4-00-45$ & 8,400 & -- & 34.5 & 410 & 48 & 70 & 2,000 & -- & 431 & 2,460 \\
\hline Do & $11-17-54$ & 8,780 & 76 & - & 400 & 51 & 66 & 2,000 & 99 & 440 & 2,460 \\
\hline 344 & $2-28-78$ & 192 & 72 & 150 & 73 & 23 & 39 & 12 & 10 & 6 & 75 \\
\hline 344 & $8-25-78$ & -- & - & -- & 61 & 20 & 28 & 84 & 20 & 5 & 66 \\
\hline 357 & $8-25-78$ & 180 & - & 190 & 56 & 18 & 28 & 15 & 15 & 9 & 57 \\
\hline 57 & $3-22-78$ & 184 & 75 & 155 & 56 & 18 & 24 & 17 & 10 & 10 & 60 \\
\hline 223 & $2-08-78$ & 404 & 75 & 170 & 109 & 27 & 95 & 49 & 41 & 20 & 173 \\
\hline 235 & $7-12-78$ & 165 & 73 & 145 & 64 & 21 & 29 & 75 & 18 & 4 & 73 \\
\hline 244 & $3-08-78$ & 379 & 77 & 215 & 130 & 42 & 59 & 26 & 40 & 10 & 135 \\
\hline 365 & $8-23-78$ & 430 & - & 340 & 190 & 50 & 150 & 30 & 45 & 10 & 160 \\
\hline
\end{tabular}

Table 5. Chemıcal analyses of water from selected wells in Owens Valley-Contınued

\begin{tabular}{|c|c|c|c|c|c|c|c|c|c|c|}
\hline $\begin{array}{c}\text { Well } \\
\text { number } \\
\text { or name } \\
\text { (fig 18) }\end{array}$ & $\begin{array}{c}\text { Sul- } \\
\text { fate } \\
\left(\mathrm{SO}_{4}\right)\end{array}$ & $\begin{array}{l}\text { Chlo- } \\
\text { ride } \\
(\mathrm{Cl})\end{array}$ & $\begin{array}{l}\text { Fluo- } \\
\text { nde } \\
\text { (F) }\end{array}$ & $\begin{array}{l}\text { Silica } \\
\left(\mathrm{S}_{1} \mathrm{O}_{2}\right)\end{array}$ & $\begin{array}{l}\text { Dis- } \\
\text { solved } \\
\text { solids, } \\
\text { calcu- } \\
\text { lated }\end{array}$ & $\begin{array}{c}\text { Nitrate } \\
\text { plus } \\
\text { nitrite } \\
\left(\mathrm{NO}_{3}+\mathrm{NO}_{2}\right. \\
\text { as } \mathrm{N})\end{array}$ & $\begin{array}{c}\text { Arse- } \\
\text { nic } \\
\text { (As) }\end{array}$ & $\begin{array}{l}\text { Bo- } \\
\text { ron } \\
\text { (B) }\end{array}$ & $\begin{array}{l}\text { Iron } \\
(\mathrm{Fe})\end{array}$ & $\begin{array}{c}\text { Man- } \\
\text { ga- } \\
\text { nese } \\
(\mathrm{Mn})\end{array}$ \\
\hline Dırty Socks & 520 & 1,600 & - & 94 & 5,400 & - & 0 & 19 & - & - \\
\hline Do & 630 & 1,600 & 10 & - & 5,400 & - & -- & 28 & - & - \\
\hline 344 & 120 & 67 & 2 & 27 & 123 & 001 & 0 & 12 & 001 & -- \\
\hline 344 & 98 & 46 & 1 & 27 & 108 & 35 & - & 08 & 04 & 001 \\
\hline 357 & 180 & 100 & 1 & 19 & 113 & .54 & - & 19 & 05 & 03 \\
\hline 57 & 160 & 78 & 1 & 17 & 109 & 04 & - & 24 & 01 & -- \\
\hline 223 & 230 & 150 & 3 & 37 & 252 & 11 & 010 & 38 & 01 & - \\
\hline 235 & 67 & 11 & 14 & 26 & 104 & 04 & 001 & 01 & 01 & - \\
\hline 244 & 560 & 32 & 21 & 71 & 276 & 02 & 010 & 08 & 03 & -- \\
\hline 365 & 810 & 63 & 20 & 58 & 325 & 75 & -- & 109 & 04 & 01 \\
\hline
\end{tabular}

dissolved-solids concentrations that ranged from 104 to 325 $\mathrm{mg} / \mathrm{L}$ and averaged 176

A study by the Los Angeles Department of Water and Power (1974) also evaluated quality of well water in the valley That study was done to evaluate (1) the present and historical quality of ground water in each of the Los Angeles Department of Water and Power well fields, (2) the significance of the quality of ground water in terms of its potential effect on water quality within the Los Angeles Department of Water and Power distribution system, and (3) any conditions of pumping that may result in degradation of quality The Los Angeles Department of Water and
Power tested all their well fields (fig 18), and water was sampled at various discharge rates The results of their chemical analyses, though not so detalled as those given in table 5, did not indicate any major differences One minor exception should be noted, however, for quality of well water pumped from the Taboose-Aberdeen well field ( $f_{1} g$ 18) Ground water in this field was found to be slightly higher in dissolved solids than water from their other well fields The Los Angeles Department of Water and Power (1974) attributed the higher dissolved solids, about 456 $\mathrm{mg} / \mathrm{L}$, to localized natural deposits of soluble minerals They also concluded that no significant changes have occurred in 
ground-water quality in the valley during the past 10 to 35 years

\section{Chemıcal Quality of Ground Water for Irrigatıon Use}

The suitability of most water for irngation depends on the amount and types of dissolved constituents in the water, on the soil type, and on the types of crops to be grown Suitability of ground water for irrigation in the valley was evaluated on the basis of the salınity and sodium (alkalınıty) hazards, boron, and other dissolved constıtu- ents The salınity hazard depends on the concentration of dissolved solids, which usually is estimated by field or laboratory measurements of specific conductance of the water and expressed in microsiemens per centımeter at 25 ${ }^{\circ} \mathrm{C}$ The specific conductance is an approximate measure of the total concentrations of the 1onized constituents in the water On the basis of chemical analyses shown in table 5, dissolved solids in ground water in the valley can be est1mated by multiplying the specific conductance by an average conversion value of 063 (based on values from this study and Los Angeles Department of Water and Power, 1974)

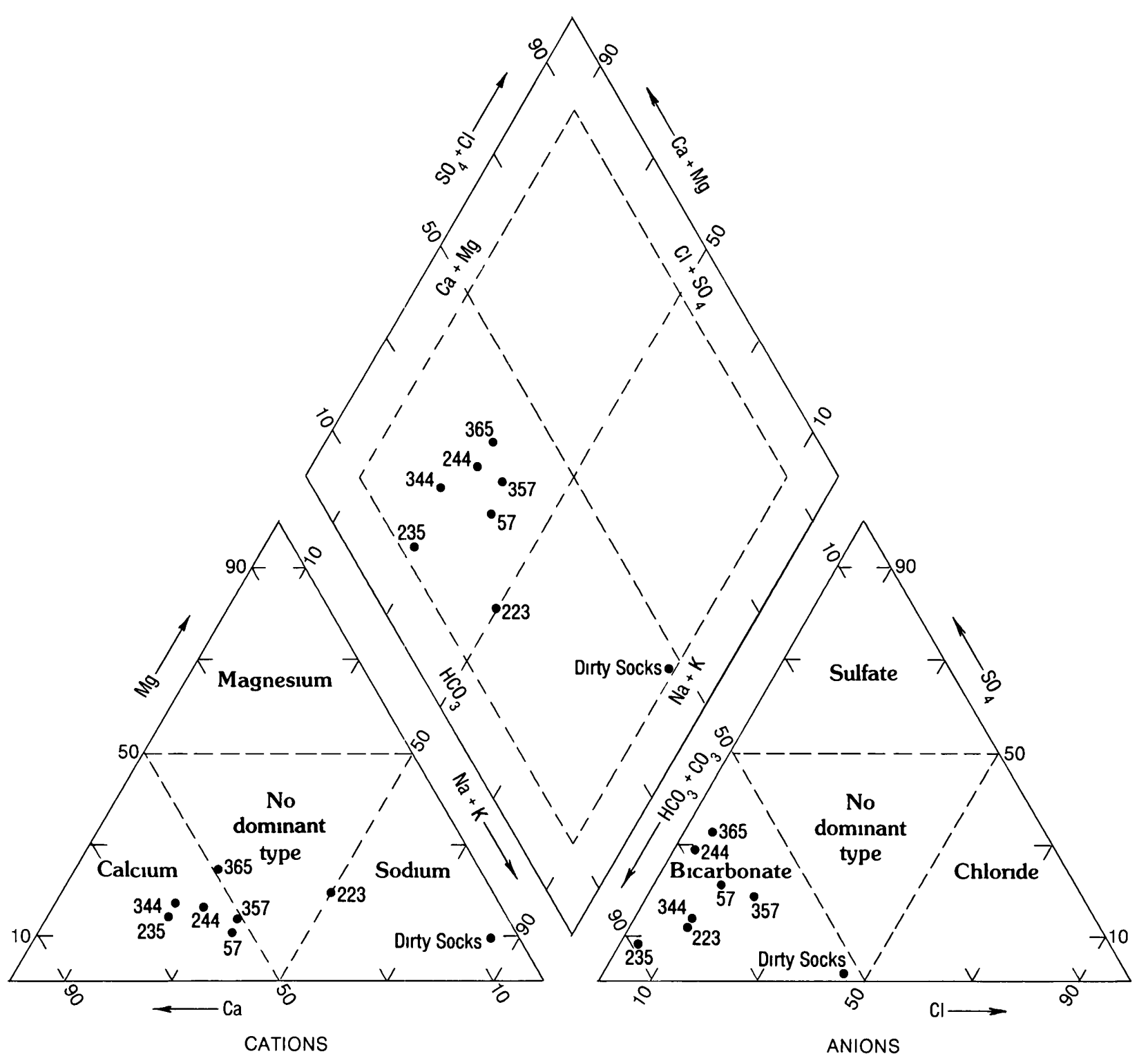

PERCENTAGE OF TOTAL MILLIEQUIVALENTS PER LITER

Figure 21. Percentages of chemical constıtuents in well water and classificatıon of major water types (see fig 18 for well locatıons) 
The sodium or alkalı hazard is indicated by the sodiumadsorption ratio $(S A R)$, which is defined by the equation

$$
S A R=\frac{\left[\mathrm{Na}^{+}\right]}{\sqrt{\frac{\left[\mathrm{Ca}^{2+}\right]+\left[\mathrm{Mg}^{2+}\right]}{2}}},
$$

in which concentrations are expressed in milliequivalents per liter The classification of irngation water with respect to $S A R$ is based primarily on the effect of exchangeable sodium on the physical conditions of the soll If the proportion of sodium among the cations is high (high value of $S A R$ ), the sodium hazard is high, but if calcium and magnesium ions dominate (low value of $S A R$ ), the sodium hazard is low

The U S Salınity Laboratory (1954, p 79-81) class1fied water with respect to salınity and sodium hazards with a four-tiered scale for each hazard For all well water sampled in the Owens Valley (table 5), with exception of water from beneath Owens Lake bed, the salınity hazard was either $\mathrm{C} 1$ $(100-250 \mu \mathrm{S} / \mathrm{cm})$ or $\mathrm{C} 2(250-750 \mu \mathrm{S} / \mathrm{cm})$ and $\mathrm{C} 4$ (greater than $2,250 \mu \mathrm{S} / \mathrm{cm}$, at the Dirty Socks well only), where

Low-salınity water (C1) can be used for irrigation with most crops on most soils with little likelihood that soil salınity will develop Some leaching is required, but this occurs under normal irrigation practıces except in solls of extremely low permeability,

Medium-salınıty water (C2) can be used if a moderate amount of leaching occurs Most plants with moderate salt tolerance can be grown without special practices for salınity control,

Very high-salınity water (C4) is not suitable for irr1- gation under ordinary conditions, but it may be used occasionally under very special circumstances The solls must be permeable, dranage must be adequate, Irrigation water must be applied in excess to provide considerable leaching, and very salt-tolerant crops should be selected

With respect to the classification for sodium hazard, the water was classified S1 (SAR of 0 to 10) or S4 (SAR greater than 26, at the Dirty Socks well only), where

Low-sodium water (S1) can be used for irngation on almost all soils with little danger of the development of harmful levels of exchangeable sodium However, sodium-sensitive crops such as stone frut trees and avocados may accumulate injurious concentrations of sodium,

Very high-sodium water (S4) is generally unsatısfactory for irrigation purposes except at low and perhaps medium salınity, where the solution of calcium from the soll or use of gypsum or other amendments may make the use of these waters feasible (U S Salınity Laboratory, 1954, p 81)

Water from the Dirty Socks well (table 5), which taps the lacustrnne sedıments of Owens Lake, is classıfied as C4-S4, an extremely poor-quality water for irrigation In general, the ground water withdrawn from the valley fill in Owens Valley, exclusive of lacustrine (lakebed) sedıments, is of excellent quality and suitable for irngation use

Chemıcal Quality of Ground Water for Publıc Supply

Chemical-quality critena used in determining the suitability of water for use in public-supply systems are generally more stringent than criteria for water to be used in agriculture The U S Environmental Protection Agency (1977a, b, 1986) has established national regulations and guidelınes for the quality of water provided by public-supply water systems in the United States Primary drinkıng-water regulations govern levels of constituents in drinkıng water that have been shown to affect human health Secondary drinkıng-water regulations apply to levels of constituents that affect esthetic quality The regulations express limits, such as "maxımum contamınant levels," where contaminant means any chemical, biological, or radiological substance in water On the basis of such limits, water from nearly all wells in Owens Valley, again with exception of wells that tap extensive layers of lacustrne clays and silts, does not contain concentrations of any constituents that are greater than the maximum contaminant levels acceptable for public supply

\section{Water Budget}

A ground-water budget is an accounting of the inflow to and outflow from the aquifer system and changes in the volume of ground water in storage If inflow equals outflow and if the change in the volume of ground water is zero, then the aquifer is in an equilibrium or steady-state condition Equilibrium is indicated by nearly constant water levels or even fluctuations of water levels with no long-term nse or declıne If total inflow does not equal total outflow, then the aquifer is in a nonequilibrium or transient condition, and the change in the volume of ground water in storage is reflected in the changing water levels

Several previous investigations have summanzed water budgets for the hydrologic system in Owens Valley $\mathrm{C} \mathrm{H}$ Lee (1912) estımated some of the components of an overall water budget for the southern part of Owens Valley using data collected for water years 1908-11 Conklıng (1921) summarized surface-water conditions in Mono Basin, Long Valley, and the northern part of Owens Valley for the period 1895 through 1920 The Calıfornı Department of Water Resources (1960) 
compiled values of surface-water runoff and estımated water use in Mono Basin, Long Valley, and Owens Valley for an unspecified period of tıme between 1894 and 1959 DE Williams (1969) compiled a generalized water budget for Owens Valley between Big Pine and Haiwee Reservoir for water years $1938-60$

Much more complete analyses were done by the Los Angeles Department of Water and Power (1972, 1974, 1976, 1978 , and 1979) for equilibrium conditions durnng water years 1935-69 and 1936-66 and for nonequilibrium conditions during water years 1971-77 As many as three different budgets, including a ground-water budget, a combined surface- and ground-water budget for the valley fill, and a more comprehensive budget that also included the hill and mountain areas, were developed for the part of Owens Valley extending from north of Bishop, excluding Round Valley, to south of Lone Pine, including Owens Lake Griepentrog and Groeneveld (1981) designed a detailed schematic of a valleywide water budget but did not calculate specific values Hutchison (1986a) extended previous work by analyzing a more recent period of approximate equilibrium, runoff years 1971-86 His approach differed from that of previous investigators in that he used stream recharge as the residual term in the water budget instead of evapotranspiration

Danskın (1988) reviewed each of the previous water budgets, except that of Hutchison (1986a), and compared the respective components of inflow and outflow He noted that data from the studies, including several by the Los Angeles Department of Water and Power, were difficult to compare because they covered either different areas or different periods of time In addition, some of the budgets used the same components of inflow and outflow but with different definitions Danskin (1988) concluded that a complete analysis of the hydrologic system of Owens Valley would require at least three interrelated water budgets for the valley-fill part of the drainage basin area. a total budget that includes all precipitation and evapotranspiration, a budget for the surface-water system, and a budget for the ground-water system To facilitate verification and comparisons, the budgets need to cover the same area and time penod and use similarly defined components

The prelımınary analysis by Danskın (1988) and subsequent detalled simulations of the ground-water-flow system (W R Danskın, U S Geological Survey, written commun, 1988, P D Rogalsky, Los Angeles Department of Water and Power, written commun, 1988, W R Hutchison, Inyo County Water Department, written commun , 1988) served as guides for the ground-water budget presented here and in table 6 Each of the components of the ground-water budget is defined and discussed separately below The area used for the budget is the major part of the Owens Valley ground-water system, which has been defined as the aquifer system in this report (fig 17), and corresponds to the area used for the related numencal evaluation of the hydrologic system (W R Danskın, U S Geological Survey, written commun, 1988) Average values for each component for two tıme periods, water years $1963-69$ and water years $1970-84$, are presented in table 6 along with the likely range of average values for the more recent period The values and ranges were defined using data from previous studies, new evapotranspiration and streamloss data collected during this 5-year study, and results of detalled simulations of the ground-water-flow system

In general, the values of recharge and discharge given in table 6 are slightly less than those in previous water budgets This decrease results primarily from changes in five components (1) less precipitation on alluvial fan deposits and volcanic rocks recharges the ground-water system, (2) less ground water enters the system as underflow from Round and Chalfant Valleys, (3) less recharge occurs from canals, ditches, and ponds, (4) less infiltration occurs from irngation and stock watering, and (5) less ground water is discharged by evapotranspiration from the valley floor

The values of individual components in table 6 illustrate the general differences between ground-water budgets before and after 1970 After the diversion of tributary streams to the aqueduct in 1913 and prior to 1970 when ground-water pumpage was substantially increased, the aquifer system probably was in a long-term penod of approxımate equilibrium After 1970, the quantity of ground-water withdrawn from pumped wells was increased, and the water budget adjusted accordingly Most of the increase in pumpage was balanced by decreased spring flows and by less evapotranspiration from the valley floor To a lesser degree, the increase in pumpage was balanced by less ground water discharging into the riveraqueduct system and by a decrease in the volume of ground water in storage, particularly in the Laws and Big Pine areas

This report emphasizes the lumped values of a groundwater budget That is, a component in the budget, such as evapotranspiration, is lumped into a single value for the entire system even though it onginally may have been calculated for separate areas in the valley Using this approach permits an encapsulated view of the system, but it also may introduce potential errors in interpreting the data or results Slight differences in total inflow or outflow for the lumped system may represent significant differences within small areas of the valley, or errors in calculating inflow for one area may coinc1dentally cancel errors in calculatung outflow for another These potential errors frequently become obvious when using a ground-water-flow model to analyze the system because the model computes separate ground-water budgets for many small areas of the valley (model cells) A more detaled description of the ground-water budget including values for each of the model cells can be found in W R Danskın (U S Geological Survey, written commun , 1988)

Ground-water budgets, such as the two listed in table 6, can be useful in making semiquantitative evaluations of an aquifer system, but budgets can easily be misinterpreted. For example, the approximation of equilibrium conditions is rarely satısfied over an entire system that has been modified by human activity Localized areas in Owens Valley will likely be undergoing change for years or decades after significant 
Table 6. Ground-water budget of the Owens Valley aquifer system

[Values of water-budget components for individual years may vary considerably from the average values presented in this table Uncertainties in the measurement and estımation of each water-budget component for water years 1970-84 are reflected in the likely range of average values The likely ranges for total recharge, total discharge, and change in ground-water storage are estımated separately for the overall aquifer system and are somewhat less than what would be computed by summing the individual ranges for respective water-budget components Values in acre-feet per year Plus $(+)$ indicates recharge to the aquifer system, minus $(-)$ indicates discharge from the aquifer system]

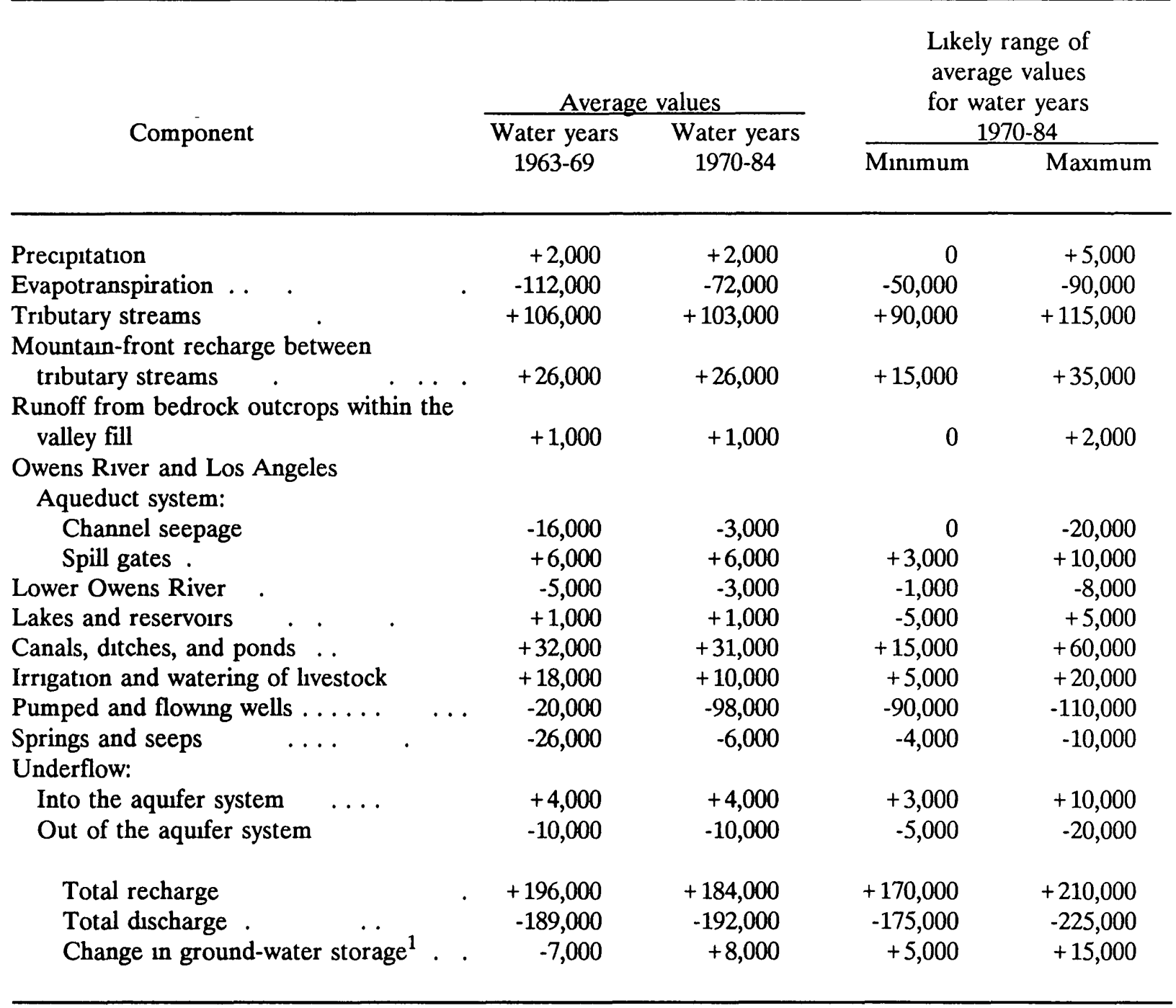

\footnotetext{
${ }^{1}$ Negative change in storage indicates water going into ground-water storage, positive change in storage indicates water coming out of ground-water storage
}

human intervention Changes in recharge or discharge, such as occurred in 1913 and 1970, are reflected in changes in the magnitude of several different components of the water budget In general, the interaction between the components is complex, and the magnitude of the changes to the hydrologic system cannot be estımated from the budget alone Bredehoeft and others (1982) reviewed some of the common pitfalls of using a ground-water budget for planning purposes For example, they stated that the magnitude of ground-water development depends on the hydrologic effects that can be tolerated, not on the quantity of natural recharge or discharge These effects are determined largely by the hydraulic properties and boundary conditions of the aquifer system, not by the water budget For this reason, the related numencal evaluation is a critical part of understanding the operation of the aquifer system and the potential effects of water-management decisions

\section{Precıpıtatıon and Evapotranspıratıon}

In general, precipitation slightly exceeds evapotranspiration in the valley, which produces a small net recharge 
through the alluvial fan deposits and volcanic rocks However, there is a substantial net discharge by evapotranspiration from the valley floor The pattern of precipitation on the valley fill is strongly influenced by altitude, and it varies in a predictable manner from approximately $6 \mathrm{in} / \mathrm{yr}$ on the valley floor to approximately $18 \mathrm{nn} / \mathrm{yr}$ at the top of alluvial fans on the west side of the valley (fig 3) On the east side of the valley, precipitation follows a similar pattern, but with somewhat lower rates because of the rainshadow effect caused by the Sierra Nevada

Extensive evapotranspiration measurements by Duell (1990) are summarized in table 7 and show that average evapotranspiration rates on the valley floor during 1984-85 ranged from about $15 \mathrm{in} / \mathrm{yr}$ to $40 \mathrm{nn} / \mathrm{yr}$, depending on the type and percentage of vegetative cover Assuming that these rates are representative of average conditions on the valley floor, where the depth to water is approximately 3 to $15 \mathrm{ft}$, then evapotranspiration is about 3 to 6 times greater than the quantity of precipitation that is avallable

In a few areas of the valley floor, infiltration to the water table may occur durng part of the year For example, in meadow areas, such as east of Independence, the water table is nearly at the land surface in winter months, and some precipitation would likely percolate to the saturated ground-water system However, the large annual evapotranspiration rates observed by Duell (1990) in those areas indicate that the meadow areas are net discharge points from the ground-water system Any water that infiltrates in winter would be removed in summer In other areas of the valley floor, such as small alkalı flats or patches that are almost devold of vegetation, net infiltration may result during unusually wet periods when rainfall or local runoff exceeds evapotranspiration As in the meadow areas, these conditions generally are present only in winter, and the quantity of infiltration, perhaps with some additional ground water, would likely be removed in summer when evapotranspiration rates increase markedly (Duell, 1990) For the area of the valley fill shown in figure 17, average net discharge by evapotranspiration from the saturated ground-water system was estımated to decrease from 112,000 acre-ft/yr for water years $1963-69$ to 72,000 acre-ft/yr for water years 1970-84 (table 6)

On the alluvial fan deposits and volcanic rocks, the depth to water ranges from many tens to hundreds of feet Extraction of water by plants from the saturated groundwater system is not possible, and the plants subsist on direct precipitation Because the precipitation rates are higher than on the valley floor, some recharge to the ground-water system may occur Any precipitation that does infiltrate past the root zone would eventually recharge the saturated ground-water system and flow toward the center of the valley Studies by C H Lee (1912) suggested that about 16 percent of the direct precipitation on the alluvial fan areas recharged the ground-water sys- tem This amount would equate to between about 125 and $275 \mathrm{in} / \mathrm{yr}$ of recharge Simulation studies by W R Danskın (U S Geological Survey, written commun, 1988), Los Angeles Department of Water and Power (P D Rogalsky, oral commun, 1988), and Inyo County Water Department (W R Hutchison, oral commun, 1988) suggest that these rates may be too high and that values of 05 to $10 \mathrm{~m} / \mathrm{yr}$ are more likely The total quantity of infiltration from direct precipitation, primarily on the alluvial fan deposits and volcanic rocks, is estımated to average approxımately 2,000 acre-ft/yr (table 6)

The conclusions drawn from this study on recharge from precipitation and discharge from evapotranspiration are in general agreement with the assumptions made in previous water-budget studies by C H Lee (1912), Los Angeles Department of Water and Power (1972, 1976, 1978, 1979), Hutchıson (1986a), and Danskın (1988), and in soll-moisture studies by Groeneveld (1986), Groeneveld and others (1986a, b), and Sorenson and others (1989) All the studies assume that a minımal quantity of recharge occurs from direct precipitation on the valley floor, generally less than 10 percent of the average precipitation rate, and that a somewhat greater potential for recharge from direct precipitation is present on the alluvial fan deposits and volcanic rocks

An important difference between this study and those proor to 1983, when the fieldwork and model simulations for this study were begun, is the assumption in this study of a lower infiltration rate from direct precipitation on the alluvial fan and volcanic areas The lower infiltration rate multıplied by the large size of the affected area results in a substantrally lower value of recharge to the saturated ground-water system This decrease in recharge is matched by a similar decrease in discharge by evapotranspiration from the valley floor In general, average evapotranspiration rates measured by Duell (1990) and transpiration rates measured by Groeneveld and others $(1986 \mathrm{a}, \mathrm{b})$ are lower than previous estımates and support the assumption of lower recharge rates from direct precipitation. Because of the recent collection of detaled evapotranspiration data on the valley floor, recharge from direct precipitation on the alluvial fan deposits and volcanic rocks is now the least quantıfied part of the water budget Additional evapotranspiration measurements or soll-moisture studies in these areas would be helpful to confirm present water-budget estımates

Tributary Streams

The largest quantity of recharge to the ground-water system is from the more than 30 tributary streams that collect water from precipitation in the Sierra Nevada and flow out across the alluvial fans (fig 16) Streamflow data for a 50year period, water years 1935-84, were used to determine the recharge for each stream and the total quantity of recharge from all tributary streams within the defined aquifer 
Table 7. Vegetatıon characterıstıcs, water-level and precıpıtatıon data, and range in evapotranspıratıon estımates for selected sites in Owens Valley

[Vegetation data from Los Angeles Department of Water and Power (written commun , 1984, 1987), evapotranspıration estımates are from Duell, 1990]

\begin{tabular}{|c|c|c|c|c|c|c|c|c|c|}
\hline \multirow{3}{*}{$\begin{array}{c}\begin{array}{c}\text { Site } \\
\text { designa- } \\
\text { tion } \\
\text { (fig 18) }\end{array} \\
1\end{array}$} & \multirow{3}{*}{$\begin{array}{c}\begin{array}{c}\text { Plant } \\
\text { community }\end{array} \\
\text { Alkalı meadow }\end{array}$} & \multirow{2}{*}{\multicolumn{2}{|c|}{$\begin{array}{cc}\text { Most common plant type } \\
\text { Common name } & \begin{array}{c}\text { Composition of } \\
\text { total vegetation } \\
\text { (percent) }\end{array}\end{array}$}} & \multirow{3}{*}{$\begin{array}{c}\begin{array}{c}\text { Total } \\
\text { vegetatıve } \\
\text { cover } \\
\text { (percent) }\end{array} \\
42\end{array}$} & \multirow{3}{*}{$\begin{array}{c}\begin{array}{c}\text { Range of } \\
\text { water levels } \\
\text { for } 1984 \\
\text { (feet below } \\
\text { land surface) }\end{array} \\
105-155\end{array}$} & \multirow{3}{*}{$\begin{array}{c}\text { Annual } \\
\text { precipitation } \\
\text { for 1984 } \\
\text { (inches) } \\
\\
\end{array}$} & \multicolumn{3}{|c|}{$\begin{array}{c}\text { Annual evapotranspiration } \\
\text { estimates for 1984-85 } \\
\text { (inches) }\end{array}$} \\
\hline & & & & & & & Maxamu & Minımu & Average \\
\hline & & $\begin{array}{l}\text { Alkah sacaton } \\
\text { Russian thistle }\end{array}$ & $\begin{array}{l}43 \\
22\end{array}$ & & & & 336 & 309 & 323 \\
\hline 2 & do & $\begin{array}{l}\text { Saltgrass } \\
\text { Rubber rabbitbrush }\end{array}$ & $\begin{array}{l}34 \\
25\end{array}$ & 35 & $102-114$ & 59 & 218 & 148 & 185 \\
\hline 3 & Alkalı scrub & $\begin{array}{l}\text { Rubber rabbitbrush } \\
\text { Alkalı sacaton } \\
\text { Mormon tea }\end{array}$ & $\begin{array}{r}24 \\
23 \\
8\end{array}$ & 26 & $102-109$ & -- & 236 & 235 & 236 \\
\hline 5 & do & $\begin{array}{l}\text { Saltgrass } \\
\text { Greasewood }\end{array}$ & $\begin{array}{l}34 \\
27\end{array}$ & 24 & $80-90$ & 63 & 189 & 119 & 152 \\
\hline 6 & Alkalı meadow & $\begin{array}{l}\text { Saltgrass } \\
\text { Alkalı sacaton } \\
\text { Rubber rabbitbrush }\end{array}$ & $\begin{array}{r}30 \\
13 \\
9\end{array}$ & 33 & $71-89$ & .. & 258 & 228 & 243 \\
\hline 7 & do & $\begin{array}{l}\text { Nevada saltbush } \\
\text { Alkalı sacaton } \\
\text { Rubber rabbitbrush }\end{array}$ & $\begin{array}{l}29 \\
21 \\
16\end{array}$ & 50 & $47-72$ & -. & 330 & 310 & 320 \\
\hline 10 & do & $\begin{array}{l}\text { Saltgrass } \\
\text { Alkalı sacaton } \\
\text { Baltic rush }\end{array}$ & $\begin{array}{l}20 \\
17 \\
15\end{array}$ & 72 & $01-39$ & 31 & 448 & 331 & 405 \\
\hline
\end{tabular}

system (fig 17) The basic technique used to estımate stream recharge is similar to that of $\mathrm{CH}$ Lee (1912) and uses the following general equation

(a)

$$
\begin{aligned}
{\left[\begin{array}{l}
\text { Stream } \\
\text { recharge }
\end{array}\right] } & =\left[\begin{array}{l}
\text { Discharge } \\
\text { at base -of- } \\
\text { mountains } \\
\text { gage }
\end{array}\right]-\left[\begin{array}{l}
\text { Discharge } \\
\text { at river- } \\
\text { aqueduct } \\
\text { gage }
\end{array}\right]+ \\
& {\left[\begin{array}{l}
\text { Add1- } \\
\text { tions } \\
\text { from } \\
\text { wells }
\end{array}\right]-\left[\begin{array}{l}
\text { Evapo- } \\
\text { trans- } \\
\text { piration } \\
\text { losses } \\
\text { along the } \\
\text { stream } \\
\text { channel }
\end{array}\right] }
\end{aligned}
$$

Annual discharge data for streams and wells were used to calculate annual recharge values for the section of each stream between the base-of-mountains and riveraqueduct gages These recharge values were evaluated in a linear regression equation in order to determine the average recharge rate, defined as stream recharge $(a)$, divided by discharge at the base-of-mountans gage $(b)$ From the regression equation, the quantity of recharge between the gages can be calculated for any known or estımated discharge at the base-of-mountains gage For water years 1963-84, annual discharge at each base-of-mountans gage was est1mated by multiplying the 50 -year average discharge at the base-of-mountains gage (table 3 ) by an index of valleywide runoff for a particular water year Recharge above or below the gaged section of the stream was determined from gaged records of diversions and by companing respective lengths of stream channels in the gaged and ungaged sections The relation for total recharge for a stream $(l)$ in water year $(l)$ can be expressed as

$$
\begin{gathered}
{\left[\text { Recharge }_{l, J}\right]=\left[\left(\frac{\text { Rate }_{l}}{100}\right) \times\left(\text { Discharge }_{l}\right) \times\left(\text { Runoff }_{J}\right)\right]+} \\
{\left[\text { Rabove }_{l, J}\right]+\left[\text { Rbelow }_{l, J}\right],}
\end{gathered}
$$$$
\text { where }
$$

Recharge is the total recharge for stream $\iota$ in water year $J$,

Rate is the average recharge rate, in percent, for stream 
$l$ as determined from the regression analysis,

Discharge is the long-term mean annual discharge at the base-of-mountains gage for stream $l$,

Runoff is a ratio of valleywide runoff for water year $J$ compared to long-term average valleywide runoff,

Rabove is an estimated quantity of recharge that occurs above the base-of-mountains gage for stream $l$ in water year $J$, and

Rbelow is an estımated quantity of recharge that occurs below the nver-aqueduct gage for stream $l$ in water year $J$

By use of this relation, recharge for each stream can be estimated both for historical periods and hypothetical scenarios, such as those used in the numerical evaluations of the hydrologic system and discussed by W R Danskin (U S Geological Survey, written commun , 1988)

Several of the streams could not be evaluated using this approach because only a single gaging station was operated on the stream, because unquantified diversions were made from one stream to another, or because a spring between the two gages added an unknown quantıty of water to the stream In these cases, an average recharge rate per foot of stream channel was calculated for streams with two gages (table 8) These recharge rates were applied to streams with similar annual discharge rates and flowing over simılar types of materials For a few streams, the long length of channel above the base-of-mountains gage produced an unrealistically high quantity of recharge, indicatıng that the stream may have been flowing on top of a narrow, fully saturated, alluvial fan or glacial'deposit that was not capable of receiving additional water from the stream (figs 7 and 16) For these sections of streams, recharge estımates were scaled downward, on the basis of a shorter recharge length for the stream and on recharge values for similar nearby streams Using these methods, the average annual recharge for all tributary streams in the aquifer system was estimated to be 106,000 acre-ft/yr for water years $1963-69$ and 103,000 acre-ft/yr for water years 1970-84 (table 6)

Data for those streams with virtually constant recharge rates over the entire 50-year period are shown in table $8 \mathrm{~A}$ few other streams, such as Lone Pine Creek, have a calculated recharge rate that fluctuates markedly from one year to another These fluctuations probably result from different management practices that alter the quantity of water diverted to or from the stream As shown in table 8, the average recharge rates calculated from the long-term discharge data are generally higher than those reported by $\mathrm{C} \mathrm{H}$ Lee (1912) The cause of the increase is not known, but it may result from the gaged sections being slightly longer, additional diversions of water from the streams, or changes to the channels, such as widening, to facilitate recharge Because part of the water diverted out of the natural channel into recharge canals may be lost to evapotranspiration, the average recharge rate in table 8 should be regarded as a maxımum rate for the section between the gages Estımated evapotranspiration losses from vegetation surrounding the stream channel do not appear to be significant The total recharge for the stream also will be affected by sections of the stream above or below the gaged section, but in most cases this additional recharge did not significantly increase the total quantity of recharge for the stream

\section{Mountaın-Front Recharge Between Trıbutary Streams}

Most runoff from precipitation fallıng on the mountains surrounding Owens Valley is measured at the base-ofmountains gaging stations on the major tributary streams Some runoff, however, occurs from precipitation falling on ungaged drainage areas between gaged tributary streams Precipitation in these small, triangular-shaped areas mapped and described by C H Lee (1912, p 13 and pl 1) runs off as sheet flow, in rivulets, or in small intermittently flowing streams Most of the runoff disappears into the alluvial fans a short distance from the edge of the mountains and contributes recharge to the ground-water system A few of the larger streams flow far enough down the alluvial fans to join a major tributary stream below the base-of-mountains gage This addition of water to the gaged tributaries is not accounted for in the estimates of stream recharge described earlier

The quantity of ungaged surface-water inflow and resultıng ground-water recharge can be estımated from precipitation records, runoff coefficients calculated for gaged drainage areas, and assumptions about the percentage of runoff that percolates to the ground-water system Using this approach, C H Lee (1912, p 66-67 and table 61) estımated the quantity of ground-water recharge resultıng from precipitation on the ungaged drainage areas in the southwestern part of Owens Valley He estımated that as much as 75 percent of the total volume of precipitation in these areas recharged the ground-water system Lee noted that the high rate was a result of steep mountain slopes, rapid meltıng of snow, and extremely permeable materials

In the present study, recharge for each of the ungaged drainage areas was estimated in a similar manner, but using different percolation rates depending on the part of the valley being analyzed Recharge for each area along the southwest side of the valley was calculated using the average annual precipitation from figure 3 and the 75-percent percolation rate suggested by $\mathrm{CH}$ Lee (1912) Recharge for areas along the northwest side of the valley was somewhat lower because of smaller drainage areas, lower precipitation values, and abundance of mountain meadows that probably discharge the ungaged water as evapotranspiration before it can reach the valley ground-water system Recharge for the Volcanic Tableland was significantly less than for areas on the west side of the valley because precipitation rates are much lower and potential evaporation is much higher owing to the higher average temperature Recharge for areas on the east side of the basin was almost zero because virtually no runoff occurs between the intermit- 
Table 8. Average annual rate of recharge between base-of-mountaıns and river-aqueduct gages for selected streams in Owens Valley

[Acre-ft/yr, acre-feet per year]

\begin{tabular}{|c|c|c|c|c|c|c|c|c|c|}
\hline \multirow[b]{2}{*}{$\begin{array}{l}\text { Site } \\
\text { No } \\
\text { (fig 16) }\end{array}$} & \multirow[b]{2}{*}{ Name } & \multirow[b]{2}{*}{$\begin{array}{c}\text { Average } \\
\text { gaged inflow } \\
\text { at base-of- } \\
\text { mountauns } \\
\text { gage } \\
(\mathrm{acre}-\mathrm{ft} / \mathrm{yr})\end{array}$} & \multicolumn{3}{|c|}{ Length of stream channel (feet) } & \multirow[b]{2}{*}{$\begin{array}{l}\text { Estımated } \\
\text { rate of } \\
\text { evapotrans- } \\
\text { piration }{ }^{1} \\
(\text { acre-ft/yr) }\end{array}$} & \multicolumn{3}{|c|}{ Average annual rate of recharge } \\
\hline & & & $\begin{array}{c}\text { Above } \\
\text { base-of- } \\
\text { mountains } \\
\text { gage }\end{array}$ & $\begin{array}{l}\text { Between } \\
\text { gages }\end{array}$ & $\begin{array}{l}\text { Below } \\
\text { ruver- } \\
\text { aqueduct } \\
\text { gage }\end{array}$ & & $\frac{\text { Water } y}{\text { (percent) }}$ & $\begin{array}{l}\text { ars } 1935-84 \\
\text { (acre-ft/yr } \\
\text { per foot } \\
\text { of stream } \\
\text { channel) }\end{array}$ & $\begin{array}{c}\text { Lee } \\
(1912)^{2} \\
\text { (percent) }\end{array}$ \\
\hline 15 & Taboose Creek & 6,685 & ${ }^{3} 10,400$ & 30,400 & 0 & 41 & 56 & 0125 & 50 \\
\hline 16 & Goodale Creek & 5,194 & 3,200 & 42,100 & 0 & 57 & 69 & 086 & 48 \\
\hline 18 & Sawmill Creek & 3,840 & 0 & ${ }^{4} 9,400$ & 0 & 13 & 54 & 221 & .. \\
\hline $20-22$ & Oak Creek & 11,992 & 24,400 & 31,700 & 0 & 43 & $5_{94}$ & 356 & 32 \\
\hline 23 & Independence Creek & 10,133 & 326,500 & 31,000 & 600 & 42 & 69 & 235 & -- \\
\hline 25 & Symmes Creek & 2,799 & 7,300 & 36,000 & 800 & 49 & 97 & 077 & 50 \\
\hline 26 & Shepherd Creek & 7,865 & 9,200 & 30,800 & 1,900 & 42 & 46 & 120 & 36 \\
\hline $27-29$ & Baurs Creek & 3,759 & 1,500 & 52,100 & 0 & 70 & 82 & 061 & 29 \\
\hline 30 & George Creek & 6,444 & 900 & 36,000 & 0 & 49 & 68 & 124 & 38 \\
\hline
\end{tabular}

\footnotetext{
${ }^{1}$ Assuming channel width of 50 feet, 30 percent vegetative cover, and 47 inches per year of evapotranspiration

${ }^{2}$ Calculated using data points and a zero intercept from Lee (1912)

${ }^{3}$ Recharge may not occur along the enture length of stream channel above base-of-mountains gage

${ }^{4}$ Stream flows in a pipe for an additional 10,500 feet

${ }^{5}$ Rate is significantly affected by many diversions
}

tently flowing tributary streams, particularly those south of Coldwater Canyon Creek

Recharge contributed from all ungaged areas was est1mated to average approxımately 26,000 acre-ft/yr for both water years 1963-69 and 1970-84 (table 6) In order to est1mate ungaged recharge for different water years, the average recharge rates were multiplied by the ratio of valleywide runoff for a particular year divided by average valleywide runoff (refer to equation 3) Although a high degree of uncertainty is associated with the values of recharge between tributary streams, for most areas of the valley, recharge from ungaged areas is a relatıvely small component of the water budget

\section{Runoff From Bedrock Outcrops Withın the Valley Fill}

A small quantity of recharge to the ground-water system probably occurs as a result of runoff from bedrock outcrops within the valley fill, in particular from Tungsten Hills, Poverty Hills, and Alabama Hills A likely range of recharge values was determined using estımates of average annual precipitation (fig 3 ) and a range of possible runoff coefficients (C H Lee, 1912) The total quantity of recharge from runoff under average conditions of precipitation and evaporation probably is less than 1,000 acre-ft/yr (table 6)

\section{Owens River and Los Angeles Aqueduct System}

In the Bishop Basin, the Owens River is the natural discharge of the surface- and ground-water systems Under unstressed ground-water conditions, the river gains water
If significant ground-water withdrawals occur in an area close to the river, then the hydraulic gradient between the ground-water system and the river may be reversed and the river will lose water to the ground-water system Hydrographs of wells near the river indicate that a reversal of gradients may occur near the Laws well field (fig 17) during periods of significant ground-water withdrawals Under these conditions, the Owens River would lose water and contribute recharge to the well field

Similar conditions may be present near the Big Pine well field The blue-green clay (hydrogeologic unit 2, pl 2 and fig 12) in this area, however, acts as a major confining bed and limits the effect of large ground-water withdrawals from hydrogeologic unit 3 on hydraulic heads in hydrogeologic unit 1, which is in contact with the Owens River In the area between Bishop and Big Pine, there is virtually no groundwater pumpage, and the Owens River undoubtedly gains water South of Tinemaha Reservorr and north of the intake to the aqueduct, springs indicate that the Owens River probably is gainıng water from the ground-water system

In the Owens Lake Basin, the Los Angeles Aqueduct is situated such that it can exchange water readily with the ground-water system As with the Owens River, the local hydraulic gradient between the aqueduct and the groundwater system determines the direction and rate of flow Hydrogeologic sections shown on plate 2 and sections developed by Gnepentrog and Groeneveld (1981) and the Los Angeles Department of Water and Power (1978) indicate the general areas where the aqueduct gains or loses water for different ground-water conditions Under average con- 
ditions, most sections of the aqueduct seem to gain water from the ground-water system Durnng periods of significant ground-water withdrawals, such as in 1971-74, groundwater levels in hydrogeologic unit 1 near the aqueduct may decline enough so that the rate of gain will decrease and perhaps even the direction of flow will change, resultıng in a loss from the aqueduct The concrete-lined section of the aqueduct next to Alabama Hills is elevated above the nearby ground-water system and would tend to lose water, however, the rate of loss probably is minimal

Estımates of the quantity of loss (or gain) for a stream or river are typically calculated as the residual of a mass balance for a gaged section of the stream This is the method used to calculate recharge for the tributary streams However, when the loss is a small fraction of the measured flows, large residual errors can result, masking the actual loss or gain For this reason, estımates of the likely range of loss or gain for the river and aqueduct were developed using loss studies on canals that flow over similai materials but have a much smaller discharge Analysis of several canals in the Bishop area indicates that a 15-foot-wide canal with a mean discharge of 2 to $10 \mathrm{ft}^{3} / \mathrm{s}$ typically loses from 03 to $11\left(\mathrm{ft}^{3} / \mathrm{s}\right) / \mathrm{m} 1$ (R H Rawson, Los Angeles Department of Water and Power, oral commun , 1988) This range of values would equate to approximately 1 to $3\left(\mathrm{ft}^{3} / \mathrm{s}\right) / \mathrm{ml}$ for the wider Owens River or Los Angeles Aqueduct, or approximately the same rate suggested by Danskın (1988) from results of a prelımınary ground-water-flow model of Owens Valley Calculated loss rates for the tributary streams as shown in table 8 also are simılar, a rate of $1\left(\mathrm{ft}^{3} / \mathrm{s}\right) / \mathrm{ml}$ is equivalent to 013 (acre- $\mathrm{ft} / \mathrm{yr}$ )/ft Because the rate of exchange (either loss or gain) between the river or aqueduct and the groundwater system is dependent on the physical characteristics of the stream channel, which are farly constant, and on the local hydraulic gradient between the stream and the groundwater system, which generally varies over a small range of values, the exchange rates probably are similar for both the gaining and losing reaches of the river and aqueduct The net value of ground-water discharge (river-aqueduct gain) in table 6 was determined by applying estimated rates of gain or loss to the respective gaining or losing sections of the river-aqueduct system

Some ground-water recharge occurs as a result of discharges from the 10 spillgates along the aqueduct The discharge, used primarily to clean the aqueduct, is measured, but the quantity of discharge that infiltrates to the groundwater system is not known Some of the discharge, especrally in high-runoff years, may flow across the valley floor to join the lower Owens River The quantity of infiltration was estımated by subtractıng the likely evapotranspiration losses and an estimate of the return flow to the lower Owens River from the measured discharge Because the discharge channels were observed to have a greater abundance of vegetation than nearby areas on the valley floor, a relatively high evapotranspiration rate of $40 \mathrm{in} / \mathrm{yr}$ (Duell, 1990) was used in the calculations The total recharge to the groundwater system from spillgates was estımated to average approximately 6,000 acre-ft/yr (table 6)

Lower Owens River

Prior to substantial surface-water diversions and ground-water withdrawals, both surface and ground water would migrate to the lower Owens River and would be discharged into Owens Lake Presently (1988), gains of surface water are virtually elıminated by diversions of runoff to the river-aqueduct system, and gains of ground water probably are less because of reduced hydraulic gradients from the ground-water system to the river The barner effect of the Owens Valley fault limits the quantity of ground water flowing eastward to most sections of the lower Owens River In addition, the fault scarp acts as a seepage face, further reducing the quantity of ground-water flow to the river Riparian vegetation on the fault scarp and in the river channel transpires much of the water that otherwise would flow in the river to Owens Lake

Hutchison (1986b) evaluated the river-discharge record at Keeler Bndge east of Lone Pine for runoff years 1946-86 using regression techniques and concluded that most streamflow at the bridge resulted either from ground-water discharge or from operational releases to the nver from the nver-aqueduct system He noted that ground-water discharge in the lower Owens River was significantly affected by bank storage By separatıng the various components of discharge, Hutchison estımated that the ground-water contributions to the lower Owens River for runoff years 1946-86 ranged from 3,000 to $11,000 \mathrm{acre}-\mathrm{ft} / \mathrm{yr}$ and averaged about 3,600 acre- $\mathrm{ft} / \mathrm{yr}$

In order to determine the gainıng and losing reaches along the lower Owens River, instantaneous discharge was measured by Los Angeles Department of Water and Power at selected sites (fig 22) during 1986-87 (W R Hutchison, Inyo County Water Department, written commun , 1987) Discharge was measured between 7 and 17 times at each site durng the period, and an attempt was made to measure all stations at the same time The range of values shown in figure 22 is the maximum loss and gain observed along each reach Reaches were defined as either gaining or losing when more than 90 percent of the discharge measurements indicated solely gains or losses, respectively Only three of the reaches were found to act in a consistent manner during the period of observations Most reaches gained or lost water depending on local cond1tions that varied from one measurement time to another As noted by Hutchison (1986b), many of the reported gains and losses probably are a result of changes in bank storage Because of these uncertainties, the characterization of the river shown in figure 22 should be considered tentative until additional data confirm the specific interaction of individual reaches The net gain of water by the lower Owens River listed in table 6 was based on results from the longer term regression analysis 
Lakes and Reservorrs

Most of the lakes in Owens Valley (Klondike, Warren, and Diaz Lakes) are topographically low points and, therefore, are most likely natural ground-water discharge areas However, if nearby pumpage rates are high, ground-water recharge may occur from these water bodies, as it probably does from the Owens River to the ground-water system near the Laws well field Recharge also may occur durnng penods of unusually high water levels in the lakes In general, this type of recharge will be temporary until water levels in the lake fall, the hydraulic gradient from the ground-water system to the lake is reestablished, and the ground-water system resumes draining This cyclical process is the same as that observed for the lower Owens River

Under natural conditiors, water levels in most lakes would fluctuate markedly from one year to another, depending on the quantity of runoff and the alttude of nearby groundwater levels In contrast, under managed conditions, such as at Klondike and Diaz Lakes, water levels in the lakes are maintained within a narrow range for recreational purposes During some parts of the year, or during extended dry penods, such as the 1976-77 drought, the lakes may act as temporary sources of recharge to the ground-water system

Pleasant Valley and Tinemaha Reservoirs, which have been created by earth-filled dams, seem to have elevated water levels compared to the surrounding ground-water system This difference suggests that the reservoirs may contribute an unknown quantity of water to the aquifer system from leakage Estımates of the quantity of leakage typically have a broad range of values because of the large residual errors that are associated with each calculation

As an aid in determınıng local recharge and discharge relations, water-level data were plotted at a scale of 162,500 using a 10-foot contour interval Within the defined aquifer system, no indications of recharge from (or discharge to) the lakes or reservoirs were evident This absence suggests that the rates of exchange with the ground-water system are probably small and localized compared to the more dominant controls on ground-water flow, such as recharge from tributary streams and discharge to the Owens River

The flat character of the potentiometric surface near Tinemaha Reservoir suggests that a ponding of surface and ground water occurs at the south end of the Bishop Basin (fig 17) During extended periods of increased ground-water withdrawals from the Big Pine well field, a hydraulıc gradıent may be established from Tinemaha Reservoir to the well field Under these conditions, the reservoir would provide additional recharge to hydrogeologic unit 1 of the aquifer system The substantial confinement caused by the thick blue-green clay (hydrogeologic unit 2) near Tinemaha Reservoir would limit interaction of the reservoir with hydrogeologic unit 3 of the aquifer system (fig 12 and $\mathrm{pl} \mathrm{2,}$ sections $C-C^{\prime}$ and $H-H^{\prime}$ ) Additional water-level measure- ments between Tinemaha Reservoir and Crater Mountain would help to confirm this possibility

The estimated average net ground-water discharge to the lakes and reservoirs as determined from mass-balance calculations for each water body and from results of model simulations of the aquifer system (W R Danskin, U S Geological Survey, written commun , 1988) is given in table 6 The broad range of average values is indicative of the high degree of uncertainty in these estımates

\section{Canals, Ditches, and Ponds}

A complex network of canals and ditches, particularly near Bishop, is used to convey water for irrigation, waterıng of livestock, and ground-water recharge Over 500 gaging stations on canals and ditches are measured contınuously by the Los Angeles Department of Water and Power in order to document the quantity of water delivered to individuals who lease lands The specific interaction of each canal and ditch with the ground-water system is not documented, but estımates can be made by comparing measurements of discharge at the different gages and subtracting estımates of water use between the gages Using this approach, Los Angeles Department of Water and Power (R H Rawson, written commun, 1988) concluded that most of the canals lose water to the ground-water system This interaction is just the opposite from that observed when the valley was first developed for farming in the late 1800's At that time, many of the canals were built to drain the solls Some localized sections of canals may stıll operate as drainage ditches

The quantity of ground-water recharge from canals and ditches varies from one year to the next depending on operatıng conditions Data for the larger canals and ditches, such as North McNally and Big Pine Canals (fig 17), indicate that loss rates of as much as $11\left(\mathrm{ft}^{3} / \mathrm{s}\right) / \mathrm{ml}$ can be sustained over a period of several months These larger conveyances typically have water flowing in them continuously except for brief periods of maintenance Most of the water flowing in them and the related recharge is from diversions of tributary streams and the Owens River However, durıng some periods, ground-water pumpage is the only source of water routed into some sections of the canals Recharge under these conditions is a localized recycling of ground water

Riparian vegetation growing in and along the canals withdraws water from the soll-moisture zone and effectively reduces the quantity of seepage that actually enters the ground-water system This reduction in actual recharge was found to be minımal (less than $002\left(\mathrm{ft}^{3} / \mathrm{s}\right) / \mathrm{ml}$ ) from calculations based on estimates of the width of vegetation ( 5 to 20 $\mathrm{ft}$ ), percentage of vegetatıve cover (30 to 100 percent), and evapotranspiration (40 to $60 \mathrm{in} / \mathrm{yr}$ ) 


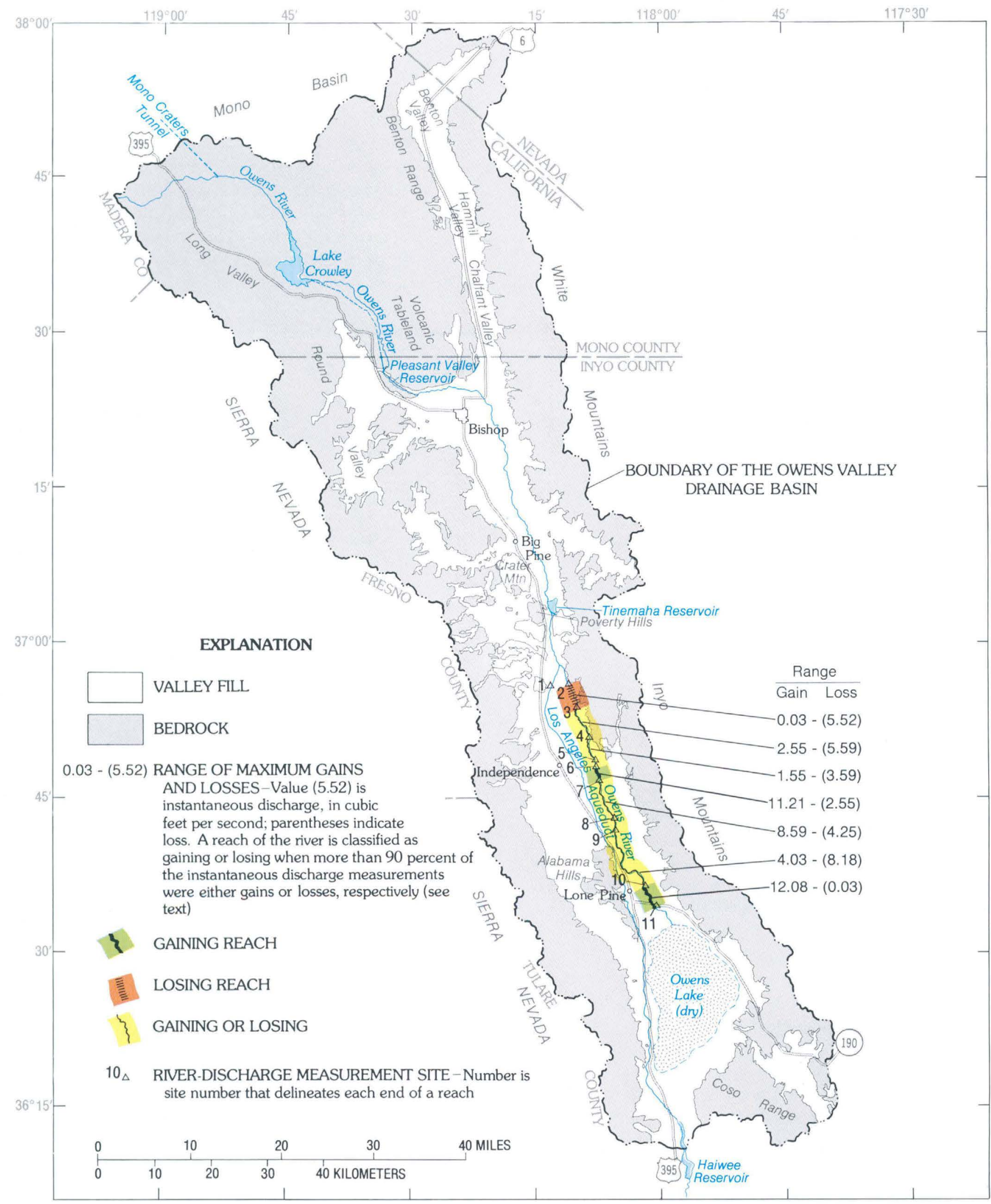

Figure 22. Water gains and losses to lower Owens River. 
An estımate of recharge for each of the larger canals and ditches was made by using an estımated loss rate, the measured length of the channel, and the average penod of operation Typically, canals lost about $07\left(\mathrm{ft}^{3} / \mathrm{s}\right) / \mathrm{m}$ and were operated all year Total recharge from the named canals and ditches was estımated to average about 20,000 acre-ft/yr

Smaller canals and ditches, which usually are unnamed, have a lower loss rate because of a smaller wetted perimeter and shallower depth of water The recharge from these conveyances was lumped into the values of recharge from irrigation and watering of livestock discussed later

Several ponds are operated in the valley for wildlife habitat and as areas to contain operational releases of surface water or to purposefully recharge the aquifer system The quantity of recharge from these areas varies with the quantity of runoff in the valley In years with below-normal runoff, little or no water is recharged In years with unusually high quantities of runoff, purposeful ground-water recharge from the ponds may be as much as 25,000 acre-ft ( $\mathrm{R} \mathrm{H}$ Rawson, Los Angeles Department of Water and Power, written commun , 1988) After operation of the second aqueduct was begun in 1970, purposeful recharge operatıons were begun in order to help balance the increased quantity of ground-water pumpage Average recharge from all ponds was estımated to be 12,000 acre-ft/yr during water years 1963-69 and 11,000 acre-ft/yr durıng water years 1970-84

Irrıgatıon and Waterıng of Lıvestock

In addition to ground-water recharge that occurs when water is conveyed in the larger canals and ditches, recharge probably occurs also from water conveyed in small, unnamed canals and ditches and from water that is applied to the land The water conveyed in the smaller canals and ditches is used primarily for sprinkler and flood irrigation of crops and pastureland and for watering of livestock Many of the historical agricultural practices, including flood irrigation and fixed water allotments, may have resulted in an excessive application of water for agricultural purposes Changes in agricultural practices since 1970, including sprinkler irrigation and levelıng of fields, may have decreased the quantity of recharge from agricultural and ranching uses in some parts of the valley

Although the quantity of recharge from these uses cannot be measured directly, it can be estımated by making assumptions about the consumptive use of the measured quantity of water that is delivered to individual parcels of land The Los Angeles Department of Water and Power (R H Rawson, written commun, 1988), using discharge records from more than 500 gaging stations and records of proposed water use on each parcel of land, estımated that average recharge from irrigation and stock waterıng since 1970 was approxımately $14,000 \mathrm{acre}-\mathrm{ft} / \mathrm{yr}$

Because similar calculations for a period prior to 1970 were not possible, another method of calculating recharge from irrigation and stock watering was used Digitızed map information describing the location of irrigated lands (R H Rawson, Los Angeles Department of Water and Power, written commun, 1988) was used with assumptions about the likely recharge rates on different types of solls Changes in water-management practices in Owens Valley about 1970 included less water being applied to irrigated lands, which are often the same as or adjacent to lands used for raising livestock As a result, the total recharge from irrigation and stock watering probably decreased Using this method, the average recharge from irngation and stock waterıng was estimated to be 18,000 acre-ft/yr in water years 1963-69 and 10,000 acre-ft/yr in water years 1970-84

Pumped and Flowing Wells

Nearly all ground water withdrawn from wells in Owens Valley is measured by the Los Angeles Department of Water and Power (Le Val Lund, written commun , 1988) Discharge from pumped wells is metered continuously, and discharge from flowing wells is estımated from intermittent readıngs at V-notch or Cipolettı weırs A few small agrıcultural or domestic wells are not measured, but the total quantity of water withdrawn from these wells probably is minımal Discharge from pumped and flowing wells is conveyed to the river-aqueduct system in pipelınes and unlıned ditches Some of the discharge from wells undoubtedly replenishes the soll-moisture zone and either leaves the valley as evapotranspiration or recharges hydrogeologic unit 1 This quantity of evaporative loss or return flow was not considered to be a significant percentage of the total withdrawals because of the short distance between most major canals or wells and the river-aqueduct system

As shown by the average values in table 6, average ground-water withdrawals have increased sharply since 1970 (20,000 acre-ft/yr for water years 1963-69 compared to $98,000 \mathrm{acre}-\mathrm{ft} / \mathrm{yr}$ for water years $1970-84$ ) Ground-water pumpage was not nearly as significant a component in the ground-water budget before 1970 as it was after completion of the second aqueduct in August 1970

Sprıngs and Seeps

Springs are present in several parts of Owens Valley including along the outcrops of volcanic tuff (the Volcanic Tableland) north of Bishop, in the middle of the valley near Tinemaha Reservorr, and along fractures north of the Alabama Hills (figs 7 and 15) Discharge from six of the larger, named springs is measured either by V-notch weirs or Parshall flumes Discharge from four smaller, named springs was estımated from nearby measured spring discharge Most of the discharge from named springs flows into streams and canals and is conveyed out of the valley, some of the dis- 
charge replenishes the scil-moisture zone and is ultımately used by plants, and some of the discharge contributes to local recharge of the ground-water system Total discharge from the named springs averaged about 33,000 acre-ft/yr during water years 1963-69 and decreased to about 8,000 acre-ft/yr during water years 1970-84 By using measurements of seepage from the larger canals in Owens Valley, the quantity of spring flow returning to the ground-water system was estimated to be approximately 7,000 and 2,000 acre-ft/yr during the two periods, respectively Therefore, the average net discharge from the ground water system was approxımately 26,000 and 6,000 acre-ft/yr during the respective periods (table 6 )

Numerous unnamed springs are present along the perimeter of the basin In general, these springs flow from bedrock fractures or from thin deposits of unconsolidated matenal Observed discharge rates range from less than 001 to greater than $2 \mathrm{ft}^{3} / \mathrm{s}$ Because the unnamed springs are located close to the surrounding mountain drainage areas and are above the actual water table, their discharge rates are highly correlated with runoff conditions As a result, recharge that likely occurs from the unnamed springs was included in the ground-water budget under the component "Mountain-front recharge between tributary streams" (table 6)

Seeps may occur along faults, at the junction of two aquifer materials with markedly different hydraulic characteristics, or where the land surface changes slope faster than the water-table gradient Generally, seepage rates are too low to produce a discharge in excess of the quantity that can be evaporated or transpired by plants For this reason, seepage discharge from the ground-water system is included in table 6 as part of evapotranspiration

\section{Underflow}

The bedrock that surrounds and underlies the valley fill 1solates the ground-water system from subsurface inflows. Although minor quantities of water flow through fractures in the bedrock, the total recharge to the defined aquifer system from fracture flow is minimal A much larger component of recharge is underflow through permeable materials adjacent to the north side of the defined aquifer system (fig 17) Recharge to the valley fill along the margins of Round Valley, through fractures and eroded parts or areas in the Bishop Tuff of the Volcanic Tableland, and along the margins of Chalfant Valley constitutes the main source of recharge for the underflow at the north end of Bishop Basin The total quantity of this inflow was estımated to be 4,000 acre-ft/yr (table 6), using transient sımulations of ground-water flow in the aquifer system (W R Danskın, U S Geological Survey, written commun, 1988) In general, the quantity of underflow that was required for calibration of the transient ground-water-flow model was significantly less than that calculated previously from Darcy's law (Los Angeles Department of Water and
Power, 1972, Danskın, 1988) or from calıbration of steadystate conditıons (Danskın, 1988) Because estımates using Darcy's law or a steady-state simulation typically have a greater uncertainty than estumates obtained by using a transient groundwater-flow model, the lower values of underflow are more likely to be correct

Underflow noted in figure 17 in the areas of Bishop and Big Pine Creeks and Waucobı Embayment was considered to be part of tributary stream recharge Most of the underflow probably originated as recharge along sections of the respective streams outside the defined area of the aquifer system

The quantity of underflow leaving the defined aquifer system is not known, it must be estımated using Darcy's law, model simulations, or a mass balance for areas north or south of the boundary Calculations using Darcy's law yield a broad range of possible values of underflow, ranging from 5,000 to more than 50,000 acre- $\mathrm{ft} / \mathrm{yr}$ A water budget developed by Lopes (1988) for the area surrounding Owens Lake suggests that 15,000 acre- $\mathrm{ft} / \mathrm{yr}$ is a reasonable value for underflow across the boundary Transient-model simulations indicate that the range of average values is approxımately 5,000 to 20,000 acre-ft/yr In order to further refine this range of estımates, more detalled data near the boundary are needed, including information on lithology, aquifer characteristics, and hydraulic-head distributions

\section{SUMMARY}

Owens Valley, a long, narrow valley located along the east flank of the Sierra Nevada in east-central Calıfornia, is the main source of water for the city of Los Angeles The city diverts most of the surface water in the valley into the Owens River-Los Angeles Aqueduct system that transports the water more than $200 \mathrm{ml}$ south to areas of distribution and use Additionally, ground water is pumped or flows from wells to supplement the surface-water diversions to the river-aqueduct system Pumpage from wells used to supplement water export has increased since 1970, when a second aqueduct from Owens Valley was put into service Local residents have expressed concern that the increased pumpage may have a detrimental effect on indigenous alkaline scrub and meadow plant communities These scrub and meadow communities depend heavily on soll moisture supplied by a relatively shallow water table

As part of a comprehensive study designed to evaluate the effects that ground-water pumpage has on the survivability of scrub and meadow plant communities in the valley and to appraise alternatıve strategies for mitigating these effects, the geology and water resources of the valley were defined, with an emphasis on the ground-water-flow system This conceptualization of the aquifer system serves as the physical and hydraulic basis for a subsequent numerical evaluation of the hydrologic system 
Owens Valley is part of the $3,300 \mathrm{mi}^{2}$ Owens Valley drainage basin area that in addition to Owens Valley includes Long, Chalfant, Hammil, Benton, and Round Valleys The Sierra Nevada and White and Inyo Mountains, which form the west and east boundaries of the valley, respectively, nse more than $9,000 \mathrm{ft}$ above the valley floor The valley floor, characterized as high-desert rangeland, ranges from about 4,500 $\mathrm{ft}$ in the north to $3,500 \mathrm{ft}$ above sea level at Owens Lake (dry) at the south end of the valley Because of the orographic effect that the Sierra Nevada has on the prevalling eastward-moving storms, most of the precipitation falls in the Sierra Nevada More than $40 \mathrm{in} / \mathrm{yr}$ falls near the crest of the Sierra Nevada, whereas rainfall on the and valley floor is about 5 to $6 \mathrm{~m} / \mathrm{yr}$

Most of the surface water in the valley originates as runoff from either rainfall or snowmelt in the Sierra Nevada More than 30 major tributary streams drain the Sierra Nevada, and most flow perennially to the valley floor The White and Inyo Mountains, in the rain shadow of the Sierra Nevada, receive significantly less precipitation Fewer than five major streams drain the White and Inyo Mountains, and they contribute little surface water to the valley Prior to construction of the Los Angeles Aqueduct in 1913, tributary flow from the mountains was to the valley trunk stream, the Owens River, which transported the water south to Owens Lake, the natural terminus of the Owens Valley drainage system After 1913, most of the runoff in the valley was diverted to the Owens River-Los Angeles Aqueduct system for export out of the valley or to local canals for Irrigation, fish hatchery, or recreational uses Consequently, flow to Owens Lake no longer balances evaporation, and the lake usually is dry

Two principal topographic features represent the surface expression of the geologic framework-the high, prominent mountains on the east and west sides of the valley and the long, narrow valley floor The mountains consist of sedimentary, granitic, and metamorphic rocks, which are mantled in part by volcanic rocks and by glacial, talus, and fluvial deposits The valley floor is underlain by valley fill that consists of unconsolidated to moderately consol1dated alluvial fan, transition-zone, glacial and talus, and fluvial and lacustrine deposits The valley fill also includes interlayered, recent volcanic flows and pyroclastic rocks The sedıments of the valley fill are mostly detritus eroded from the surrounding bedrock mountains Nearly all the ground water that occurs in Owens Valley is transmitted and stored in the valley fill The bedrock, which surrounds and underlies the valley fill, is virtually impermeable

The structure and configuration of the bedrock surface beneath Owens Valley define the areal extent and depth of the valley fill and therefore affect the movement and storage of ground water The bedrock surface beneath the valley is a narrow, steep-sided graben, divided into two structural basins-Bishop Basin and Owens Lake Basin The two basins are separated by east-west-trending normal faults, a block of bedrock material (Poverty Hills), and recent olıvine basalt flows and cones (Big Pine volcanic field) The combined effect of the normal faults, which create a bedrock high, the upthrown block of the Poverty Hills, and the Pleistocene olivine basaltıc rocks forms a "narrows," which separates the sedimentary depositional systems of the two basins The Bishop Basin includes Round, Chalfant, Hammıl, and Benton Valleys, which are partly burıed by the Volcanic Tableland, and extends south to the "narrows," opposite Poverty Hills The deepest part of the bedrock surface in Bishop Basin is located between Bishop and Big Pine and is about 4,000 ft below the land surface To the south, the bedrock surface rises to approximately 1,000 to $1,500 \mathrm{ft}$ in the "narrows" The bedrock surface in Owens Lake Basin deepens southward from 1,000 to $1,500 \mathrm{ft}$ at the "narrows" to approxımately $8,000 \mathrm{ft}$ below Owens Lake (dry) The bedrock of the Coso Mountains forms the south end of Owens Lake Basin

During deposition of the valley-fill deposits, the Bishop and Owens Lake Basins acted as loci of deposition, separated by the bedrock high at the "narrows," and later, by basaltic flows and cones Both basins supported ancient, shallow lake systems at different times during their historical evolution Lake sedimentation, as evidenced by lacustrine, deltaic, and beach deposits, is interrupted periodically in the geologic section of both basins by fluvial deposits Coincident with deposition of lake sediments and fluvial deposits in the center of the basins was alluvial fan deposition and beach, bar, and stream deposition of the transition zones along the margins of each basin As the mountain blocks were eroded and the fronts receded, the alluvial fan deposits thickened The fans are thicker and more extensive on the wetter, west side of the valley than on the east side and have displaced the Owens River east of the center of the valley

The depositional subunits of the valley fill in both basins can be conceptualized by using three depositional models These models depict specific depositional patterns that interrelate and provide a means of subdividing the heterogeneous valley-fill sediments into depositional subunits with similar lithologic and hydrologic characteristics The geologic and geophysical signature of each depositional pattern is useful as an aid in recognizing specific depositional subunits from field data or in conceptualızing the hydrogeologic system in areas where no data are avallable

Ground water is an important source of invalley water for fisheries, domestic, irngation, stockwater, recreation, and wildlife use, ground water also supplements surface-water runoff for export to Los Angeles Nearly all the recoverable ground water in the valley is pumped from the saturated valley fill The defined aquifer system, composed entırely of saturated valley fill, is a subset of the ground-water system The upper surface of the aquifer system is the water table, and the bottom, for purposes of this study, is defined as (1) the bedrock, (2) the top of moderately consolidated 
valley-fill material, or (3) an arbitrary depth of $1 \mathrm{~A}$ times the depth of the deepest production well in a specific area The internal framework of the aquifer system is subdivided vertically into hydrogeologic units on the basis of either uniform hydraulic characteristics or on a substantial difference in vertical head Three hydrogeologic units compose the aquifer system and a fourth represents the valley fill below the aquifer system and above the bedrock Hydrogeologic unit 1 is the unconfined part of the aquifer system, hydrogeologic unit 2 is a confining bed, volcanic rock layers, or a series of clay lenses at the same depth that emulate a confinıng bed, and hydrogeologic unit 3 is the confined part of the aquifer system, the bottom of which is the base of the aquifer system Hydrogeologic unit 4 is not considered a part of the aquifer system because it transmits or stores much less water than hydrogeologic unit 3 Volcanic rocks, where present in the system, represent a part of a single hydrogeologic unit or are included in one of the three hydrogeologic units that compose the aquifer system

Nearly all the ground water in the aquifer system is derived from infiltration of runoff that originates as precipitation on the mountains surrounding the valley fill Most of the infiltration to the aquifer system comes from the Sierra Nevada through the heads and middle of the alluvial fans, through the tributary stream channels, or to a lesser extent from the river-aqueduct system The ground-water-flow pattern is from the margins of the valley toward the valley axis and then south along the axis to the south end of the valley to intermediate points of discharge Recharge on the alluvial fans moves downgradient toward the center of the valley, splits at the toes of the alluvial fans, and horizontally recharges fluvial and lacustrine deposits of hydrogeologic units 1 and 3

Discharge from the aquifer system is primarily by pumpage and evapotranspiration, and to a lesser extent by flowing wells, springs, underflow, or leakage to the riveraqueduct system Withdrawal from pumped or flowing wells is the largest component of discharge, and it accounts for about 50 percent of the outflow from the system Transplration by scrub and meadow plant communities, and to a lesser extent, irngated alfalfa pasture, stockwater, recreation, and wildlife habitats, accounts for about 40 percent of the system discharge

The hydraulic characterıstics for each hydrogeologic unit and depositional subunit are based on the specific mode of deposition or rock type that composes the hydrogeologic unit The olivine basalt flows interlayered with the depositoonal subunits in the Big Pine area are the highest yielding materials in the aquifer system Natural hydraulic conductıvity averages about $1,200 \mathrm{ft} / \mathrm{d}$ and probably ranges from 400 to $12,000 \mathrm{ft} / \mathrm{d}$ Actual transmissivities in the basalt flows are generally greater than $1,000,000 \mathrm{ft}^{2} / \mathrm{d}$ as a result of fracturing created by drilling techniques and use of explosives in the well bore The sandy gravels and cobbles of the transition-zone subunit have transmissivities second to the basalt flows Hydraulic conductivities of the depositional and rock subunits in hydrogeologic units 1 and 3 are highly variable, depending on lithology and texture

Numerous faults cut the valley fill, and many of them are onented transverse to regional ground-water-flow paths These faults tend to retard ground water that moves from points of recharge along the margins of the valley toward the valley center The Owens Valley fault, for example, acts as a barrier to ground-water movement and effectively divides the aquifer system in the northern part of Owens Lake Basin into east and west halves Other faults in the valley also retard ground-water movement but not to the same extent as the Owens Valley fault

The degree of confinement depends on the vertical hydraulic conductivity and thickness of the confining beds Where the bed is absent or is present as thin discontinuous lenses or beds of clay, little confinement occurs, and hydrogeologic units 1 and 3 act as a single unconfined aquifer This condition is most common in the alluvial fan deposits The lacustrine sediments of the fluvial and lacustrine subunit, composed of fine silts and clays, are the primary confinıng beds in the aquifer system Volcanic flows interlayered with valley-fill sediments also act as confining beds The zones of confinement in the valley generally increase to the south and east in both basins and are controlled by asymmetric recharge to the valley and the extent and thickness of the lacustrine clay layers of hydrogeologic unit 2 The thickness and extent of lacustrine clays increase southward in each basin, coincident with the ancient centers of lake deposition An example of a lacustrine clay that was associated with ancient lake deposition is the massive blue-green clays at the south end of Bishop Basin These clays make up part of hydrogeologic unit 2 in Bishop Basin and are about $100 \mathrm{ft}$ thıck, extendıng and thinnıng from the "narrows" opposite the Poverty Hills north to Big Pine Overlapping lenses of lacustrine clay in the Independence area that were associated with deposition in the Owens Lake Basin emulate a confinıng bed that extends from the toes of the alluvial fans east to the Owens Valley fault and south to merge with the thick lacustrine clay in the Owens Lake area Because of the lentold shape of this and other clay beds in the Owens Lake Basin, the degree of confinement varies from one part of the basin to another As a result of the dominant recharge from the Sierra Nevada, vertical hydraulic gradients across hydrogeologic unit 2 in both basins range from 1 to $2 \mathrm{ft}$ at the toes of the Sierra Nevada fans to more than $30 \mathrm{ft}$ in the center of the valley The gradient is generally upward from hydrogeologic unit 3 to unit 1 throughout most of the confined areas of the valley, except where altered by pumping

The water in the aquifer system is generally of excellent quality and is suitable for public supply and irngation, with exception of water stored in thick sequences of lacustrine silt and clay near Owens Lake The water is principally a calcium bicarbonate type with dissolved concen- 
trations that range from about 104 to $325 \mathrm{mg} / \mathrm{L}$ Water in the sediments of Owens Lake (dry) is a sodium bicarbonate type, and dissolved-solids concentration is about $5,400 \mathrm{mg} / \mathrm{L}$

Ground-water pumpage, the largest discharge from the aquifer system, has changed appreciably since the first wells were drilled at the turn of the 20th century Between the activation of the first Los Angeles Aqueduct in 1913 and the second in 1970, most of the water pumped from the ground-water system was for irngation during a period of heavy agricultural development in the 1920's and to supplement export during the dry periods of 1930-31 and 196062 Water was pumped primarily from hydrogeologic unit 3 in the valley After activation of the second aqueduct in 1970 , more water was exported, particularly during the dry period of 1976-77 Although most of the increased pumpage was withdrawn from hydrogeologic unit 3 , some long-term water-level declines also were recorded in the wells that tap unit 1 Drawdown in hydrogeologic unit 1 is due to (1) changes in the flow rate of ground water between hydrogeologic units 1 and 3 through the confining beds, (2) downward leakage of water from hydrogeologic unit 1 to unit 3 through existing wells, (3) increased evapotranspiration, (4) decreased horizontal flow into hydrogeologic unit 1 from recharge areas, and (5) direct withdrawal by wells that pump from open intervals in hydrogeologic unit $1 \mathrm{~A}$ quantification of the aquifer system changes caused by pumping, using the boundary conditions and the groundwater-flow regime established by this report, is presented in a companion report that summarizes results from a numer1cal evaluation of the hydrologic system

\section{SELECTED REFERENCES}

Allmendinger, R W , Hauge, T A, Hauser, E C , Potter, C J , Klemperer, S L, Nelson, K D , Knuepfer, P, and Oliver, J, 1987, Overview of the COCORP 40 degrees north transect, western United States The fabric of an orogenic belt Geological Society of America Bulletın, v 98, no 3, p 308-319

An, Kyung-Han, 1985, Barometric effects on diurnal ground-waterlevel changes in Owens Valley, Calıforna Irvine, Unıversity of California, School of Engineering, M S thesis, $105 \mathrm{p}$

Anderson, R E , Zoback, M L , and Thompson, G A , 1983, Impl-cations of selected subsurface data on the structural form and evolution of some basins in the northern Basin and Range province, Nevada and Utah Geological Society of America Bulletın, v 94, no 9, p 1055-1072

Bachman, S B , 1974, Depositional and structural history of the Waucobı lake bed deposits, Owens Valley, Calıfornı Los Angeles, University of California, M S thesis, $129 \mathrm{p}$

1978, Pliocene-Pleistocene break-up of the Sierra NevadaWhite-Inyo Mountains block and the formation of Owens Valley Geology, v 6, no 8, p 461-463

Bacon, C R , Giovannettı, D M , Duffield, W A , and Dalrymple, G B , 1979, New constraints on the age of the Coso Formatıon, Inyo County, Calıfornıa Geological Society of Amenca, Abstracts with Programs, v 11, no 3, p 67
Bacon, C R , Gıovannettı, D M , Duffield, W A , Dalrymple, G B , and Drake, RE, 1982, Age of the Coso Formation, Inyo County, Calıfornıa U S Geologıcal Survey Bulletın 1527, 18 p

Balley, GE , 1902, The salıne deposits of Calıfornıa Calıfornıa State Mınıng Bureau Bulletın 24, $194 \mathrm{p}$

Balley, R A , 1984, Introduction to the late Cenozoic volcanısm and tectonics of the Long Valley-Mono Basın area, eastern Calıfornia, in Lintz, J, Jr, ed, Western Geological Excursions, v 2 Geological Society of America, Field Guidebook, p 56-67

Balley, R A , Dalrymple, G B , and Lanphere, M A , 1976, Volcanism, structure, and geochronology of Long Valley caldera, Mono County, Calıfornı Journal of Geophysical Research, v 81 , no 5 , p 725-744

Ball, S H , 1907, A geologic reconnaissance in southwestern Nevada and eastern Calıfornıa U S Geological Survey Bulletın $308,218 \mathrm{p}$

Batchelder, G L , 1970, Post-glacial fluctuations of lake level in Adobe Valley, Mono County, Calıfornıa Amerıcan Quaternary Association, 1st, Yellowstone Park and Montana State University, Bozeman, August 28-September 1, 1970, Abstracts, $\mathrm{p} 7$

Bateman, P C , 1961, Willard D Johnson and the strike-slip component of fault movement in the Owens Valley, Calıfornı earthquake of 1872 Bulletın of Seismological Society of America, v 51, no 4, p 483-493

1965, Geology and tungsten mineralızation of the Bishop district, Calıfornia, with a section on Gravity study of Owens Valley by L C Pakıser and MF Kane, and a section on Seısmic profile by L C Pakıser U S Geological Survey Professional Paper 470, $207 \mathrm{p}$

1978, Map and cross section of the Sierra Nevada from Madera to the White Mountains, central Calıfornı Geolog1cal Society of America, map sheet, MC-28E', scale 1250,000

Bateman, P C , Clark, L D , Huber, N K , Moore, J G , and Rinehart, C D , 1963, The Sierra Nevada batholith A synthesis of recent work across the central part US Geological Survey Professional Paper 414-D, $46 \mathrm{p}$

Bateman, P C , Erickson, M P , and Proctor, P D , 1950, Geology and tungsten deposits of the Tungsten Hills, Inyo County, Calıfornıa Calıfornı Journal of Mines and Geology, v 46, no $1, \mathrm{p} 23-42$

Bateman, P C, and Merriam, C W , 1954, Geologic map of the Owens Valley regıon, Calıfornıa Calıfornı Divisıon of Mines and Geology Bulletın 170, map sheet 11, scale 1250,000

Bateman, P C , and Moore, J G , 1965, Geologic map of the Mount Goodard quadrangle, Fresno and Inyo Counties, California U S Geological Survey Geologic Quadrangle Map GQ-429, scale 162,500

Bateman, P C, and Wahrhaftig, C, 1966, Geology of the Sierra Nevada, in Bailey, E H, ed, Geology of northern Calıfornıa Calıfornıa Divisıon of Mines and Geology Bulletın 190, p 107172

Beanland, S L, and Clark, M M , 1987, The Owens Valley fault zone, eastern Calıfornia and surface rupture associated with the 1872 earthquake [abs] Seismological Research Letters, Seismological Society of America, v 58, no 1, p 32

Beaty, C B , 1963, Origin of alluvial fans, White Mountains, Calıfornia and Nevada Annals of the Association of American Geographers, v 53, no 4, p 516-535 
Benham, S , 1987, Various changes in some of the natural and cultural features that may influence the water resources of Owens Valley, Calıfornia, as observed from maps of the area Northndge, Calıfornia State University, B S honors thesis, $30 \mathrm{p}$

Bırman, J H , 1964, Glacial geology across the crest of the Sierra Nevada, Calıfornia Geological Society of Amenca Special Paper 75, $80 \mathrm{p}$

Blackwelder, E , 1928, Mudflow as a geologic agent in semiand mountains Geological Society of America Bulletın, v 39, no 6, p $465-480$

1931, Pleistocene glaciation in the Sierra Nevada and basinrange Geological Society of America Bulletın, v 42, no 4, p 865-922

1954, Pleistocene lakes and drainage in the Mojave region, southern Calıfornı, chap 5, in Jahns, R H, ed, Geology of southern Calıfornıa Calıfornia Division of Mines and Geology Bulletın 170, p 35-40

Blakely, R J , and McKee, E H , 1985, Subsurface structural features of the Salıne Range and adjacent regions of eastern Cal1fornıa as interpreted from isostatic residual gravity anomalıes Geology, v 13, no 11, p 781-785

Bredehoeft, J D , Papadopulos, S S , and Cooper, H H , 1982, Groundwater The water budget myth, in Scientıfic basis of water resource management Washıngton, D C , National Research Counc1l, p 51-57

Brook, C A , 1977, Stratıgraphy and structure of the Saddlebag Lake roof pendant, Sierra Nevada, Calıfornıa Geological Society of America Bulletin, v 88, no 3, p 321-334

Bryant, W A , 1984, Evidence of recent faultıng along the Owens Valley, Round Valley, and White Mountains fault zones, Inyo and Mono Countıes, Calıfornıa Calıfornı Division of Mines and Geology, Open-File Report 84-54 SAC, scale 124,000

Calıfornı Department of Health Services, 1983, Prımary drınkıng water standards Calıfornı Department of Health Services, Sanitary Engıneerıng Department, 1 table

Calıfornı Department of Water Resources, 1960, Reconnaissance investigation of water resources of Mono and Owens Basıns, Mono and Inyo Counties $92 \mathrm{p}$

Calıfornıa Division of Mines and Geology, 1982, Bouguer gravity map of Calıforna, Mariposa sheet scale 1250,000

Campbell, M R , 1902, Reconnaissance of the borax deposits of Death Valley and Mohave Desert US Geological Survey Bulletın 200, 23 p

Carver, G A , 1970, Quaternary tectonısm and surface faultıng in the Owens Lake Basın, Calıfornı University of Nevada, Mackay School of Mines, Technical Report AT-Z, 103 p

Casteel, M V , 1986, Geology of a portion of the west-central Last Chance Range, Inyo County, Calıfornı Geological Society of America, Abstracts with Programs, v 18, no 2, p 94

Cehrs, D , 1979, Depositional control of aquifer characterıstics in alluvial fans, Fresno County, Calıfornı-Summary Geological Society of America Bulletın, v 90, no 8, p 709-711

Chapman, R H , Healey, D L, and Troxel, B W , 1973, Bouguer gravity map of Calıfornia, Death Valley sheet Calıfornı D1vision of Mines and Geology, scale 1 250,000, 8 p

Christensen, M N , 1966, Late Cenozoic crustal movement in the Sierra Nevada Geological Society of America Bulletın, v 77, no 2 , p 163-182

Clark, D W , 1984, The ground-water system and simulated effects of ground-water withdrawals in northern Utah Valley, Utah
U S Geologıcal Survey Water-Resources Investıgatıons Report $85-4007,56 \mathrm{p}$

Cleveland, G B , 1958, Poverty Hills diatomaceous earth deposit, Inyo County, Calıfornia Calıfornıa Journal of Mines and Geology, v 54, no 3, p 305-316

Conklıng, H , 1921, Report on Owens Valley project, Calıfornıa U S Reclamation Service, $86 \mathrm{p}$

Conrad, J E , Kılburn, J E, Blakely, R J, Sabıne, Charles, Cather, E E, Kuizon, Lucia, and Horn, M C , 1987, Mineral resources of the southern Inyo wilderness area, Inyo County, Calıfornı U S Geological Survey Bulletın 1705, 28 p

Conrad, J E, and McKee, E H , 1985, Geologic map of the Inyo Mountains wilderness study area, Inyo County, Calıfornı U S Geological Survey Miscellaneous Field Studies Map MF-1733A, scale 162,500

Crowder, D F , McKee, E H , Ross, D C , and Krauskopf, K B , 1973, Granitıc rocks of the White Mountains area, CalıfornıNevada Age and regional significance Geological Society of Amenca Bulletın, v 84, no 1, p 285-296

Crowder, D F, Robınson, P F , and Harris, D L , 1972, Geologic map of the Benton quadrangle, Mono County, California, and Esmeralda and Mineral Counties, Nevada U S Geological Survey Geologic Quadrangle Map GQ-1013, scale 162,500

Crowder, D F , and Ross, D C , 1972, Permian(?) to Jurassic(?) metavolcanic and related rocks that mark a major structural break in the northern White Mountains, California-Nevada U S Geological Survey Professional Paper 800-B, p B195B203

Crowder, DF, and Sheridan, MF, 1972, Geologic map of the White Mountain Peak quadrangle, Calıfornı U S Geological Survey Geologic Quadrangle Map GQ-1012, scale 1 62,500

Dalrymple, G B , 1963, Potassium-argon dates of some Cenozoic volcanıc rocks of the Sierra Nevada, Calıformı Geological Society of America Bulletın, v 74, no 4,p 379-390

-1964a, Cenozoic chronology of the Sierra Nevada, Calıfornıa Berkeley, Unıversity of Calıfornıa, Publıcatıons in Geological Sciences, v 47, p 1-41

1964b, Potassium-argon dates of three Pleistocene interglacial basalt flows from the Sierra Nevada, Calıfornia Geological Society of Amenca Bulletın, v 75, no 8, p 753-757

Dalrymple, G B , Cox, A , and Doell, R R , 1965, Potassium-argon age and paleomagnetism of the Bishop Tuff, Calıfornı Geological Society of Amenca Bulletin, v 76, no 6, p 665-674

Danskın, W R , 1988, Prelımınary evaluation of the hydrogeologic system in Owens Valley, Calıfornı U S Geological Survey Water-Resources Investigations Report 88-4003, 76 p

Davis, S N , 1969, Porosity and permeability of natural materials, in DeWiest, R J M , ed , Flow through porous media New York, Academic Press, p 54-90

Davıs, W M , 1933, The lakes of Calıfornıa Calıfornia Journal of Mines and Geology, v 29, nos 1 and 2, p 175-236

dePolo, C M , 1988, Styles of faulting along the White Mountains fault system east central Calıfornı and west central Nevada [abs ] Geological Society of America, Abstracts with Programs, v 20, no 3, p 155

dePolo, C M , and dePolo, D M , 1987, Microseismicity in the northern Owens Valley and Chalfant Valley areas Reno, Unıversity of Nevada, Seismological Laboratory Report I-2, $36 \mathrm{p}$

Dileanıs, P D , and Groeneveld, D P , 1989, Osmotic potential and projected drought tolerances of four phreatophytic shrub spe- 
cıes in Owens Valley, Calıfornı U S Geological Survey Water-Supply Paper 2370-D, $21 \mathrm{p}$

du Bray, E A , and Moore, J G , 1985, Geologic map of the Olancha quadrangle, southern Sierra Nevada, Calıformia U S Geolog1cal Survey Miscellaneous Field Studies Map MF-1734, scale 162,500

Duell, L F W , Jr , 1985, Evapotranspiration rates from rangeland phreatophytes by the eddy-correlation method in Owens Valley, Calıfornia [extended abs ] 17th Conference on Agnicultural and Forest Meteorology and 7th Conference on Biometerology and Aerobiology, 1985, Scottsdale, Arız, Proceedings, $p$ 44-47

1990, Estımates of evapotranspiration in alkalıne scrub and meadow communities of Owens Valley, California, using the Bowen-ratio, eddy-correlation, and Penman-combination methods U S Geological Survey Water-Supply Paper 2370 E, $39 p$

Duell, L F W , Jr, and Nork, D M, 1985, Companson of three micrometeorological methods to calculate evapotranspiration in the Owens Valley, California Riparian ecosystems and their management Reconciling conflictıng uses, North American Riparian Conference, 1st, April 1985, Tucson, Arız, Proceedings, p 161-165

Duffield, W A , and Bacon, C R , 1981, Geologic map of the Coso volcanıc field and adjacent areas, Inyo County, Calıfornı U S Geological Survey Miscellaneous Investigations Map MF-1200, scale 150,000

Duffield, W A, Bacon, C R, and Dalrymple, B G, 1980, Late Cenozoic volcanism, geochronology, and structure of the Coso Range, Inyo County, Calıfornia Journal of Geophysical Research, v 85, no B5, p 2381-2404

Duffield, W A , and Smith, G I , 1978, Pleistocene history of volcanism and the Owens River near Little Lake, California U S Geological Survey Journal of Research, v 6, no 3, p 395-408

Dunne, G C , and Gullıver, R M , 1978, Nature and significance of the Inyo thrust fault, eastern California discussion and reply Geological Society of America Bulletın, v 89, p 1787-1792

Dutcher, L C, and Moyle, W R , 1973, Geologic and hydrologic features of Indian Wells Valley, Calıfornia US Geological Survey Water-Supply Paper 2007, $30 \mathrm{p}$

Ekren, E B , Bucknam, R C , Carr, W J , Dixon, G L , and Quınlıvan, W D , 1979, East-trending structural lineaments in central Nevada U S Geological Survey Professional Paper 986, $16 \mathrm{p}$

Ekren, E B , Rogers, C L , Anderson, R E , and Orkıld, P P , 1968, Age of Basin and Range normal faults in Nevada Test Site and Nellis Air Force Range, Nevada, in Nevada Test Site Geolog1cal Society of America Memoir 110, p 247-250

Elliott, G S , and McKee, E H , 1982, Geologic map of the Coyote SE and Table Mountain roadless areas, Inyo County, Californıa U S Geological Survey Miscellaneous Field Studies Map MF-1426-A, scale 162,500

Evernden, J F , and Kistler, R W , 1970, Chronology of emplacement of Mesozoic batholithic complexes in Calıfornia and western Nevada US Geological Survey Professional Paper $623,42 \mathrm{p}$

Fenneman, N M , 1931, Physiography of Western United States New York, McGraw-Hill, $534 \mathrm{p}$

Fenneman, N M , and Johnson, D W , 1946, Physical divisions of the United States U S Geological Survey Map, scale $17,000,000$
Feth, J H , 1964, Review and annotated biblography of ancient lake deposits (Precambrian to Pleistocene) in the Western United States U S Geological Survey Bulletın 1080, $119 \mathrm{p}$

Franke, O L, Reilly, T E, and Bennett, G D , 1987, Definition of boundary and initial conditions in the analysis of saturated ground-water flow systems-An introduction U S Geological Survey Techniques of Water-Resources Investıgations, Book 3, chapter B5, $15 \mathrm{p}$

Freeze R A , and Cherry, J A , 1979, Groundwater Englewood Cliffs, N J , Prentice-Hall, 604 p

Gale, H S , 1915, Salınes in the Owens, Searles, and Panamınt basıns, southeastern Calıfornıa U S Geological Survey Bulletın 580, p 251-323

Gilbert, C M , 1938, Welded tuff in eastern Calıfornia Geological Society of America Bulletın, v 49, no 12, p 1829-1861

Gilbert, C M , and Reynolds, M W , 1973, Character and chronology of basin development, western margin of the Basin and Range province Geological Society of America Bulletın, v 84, no 8, p 2489-2509

Gllbert, G K , 1885, The topographic features of lake shores U S Geological Survey Fifth Annual Report, p 75-123

1928, Studies of Basin-Range structure U S Geological Survey Professional Paper 153, 92 p

Gillespie, A R , 1982, Quaternary glaciation and tectonısm in the southeastern Sierra Nevada, Inyo County, Calıfornia Pasadena, Calıfornı Institute of Technology, Ph D dissertation, $695 \mathrm{p}$

Giovannettı, D M , 1979a, Mio-Pliocene volcanıc rocks and assoc1ated sediments of southeastern Owens Lake, Inyo County, Calıfornı Berkeley, Unıversity of Calıformia, M S thesıs, $76 \mathrm{p}$ $-1979 \mathrm{~b}$, Volcanism and sedimentation associated with the formation of southern Owens Valley, Calıfornia Geological Society of America, Abstracts with Programs, v 11, no 3, p 79

Greene, G W , and Hunt, C B , 1960, Observations of current tıltıng of the Earth's surface in the Death Valley, Calıfornia, area U S Geological Survey Professional Paper 400-B, p B275B276

Griepentrog, T E, and Groeneveld, D P , 1981, The Owens Valley management report Final report for Inyo County, Bishop, Calıfornia, $272 \mathrm{p}$

Groeneveld, D P , 1986, Transpiration processes of shallow groundwater shrubs and grasses in the Owens Valley, California Rootıng relationshıps Report of Inyo County Water Department and city of Los Angeles Department of Water and Power to Calıfornia Water Resources Control Board, $81 \mathrm{p}$

Groeneveld, D P , Warren, D C , Hubbard, P J , and Yamashita, I S , 1986a, Transpiration processes of shallow ground-water shrubs and grasses in the Owens Valley, Calıfornia, Phase I Steady state conditions Report of Inyo County Water Department and city of Los Angeles Department of Water and Power to Calıfornia Water Resources Control Board, $130 \mathrm{p}$

Groeneveld, D P, Warren, D C , Hubbard, P J , Yamashita, I S , and Manning, S J , 1986b, Transpiration processes of shallow ground-water shrubs and grasses in the Owens Valley, Calıfornia Report of Inyo County Water Department and city of Los Angeles Department of Water and Power to Calıfornia Water Resources Control Board, $48 \mathrm{p}$

Guymon, G L , and Yen, Chung-Cheng, 1990, An efficient determinıstic-probabilıstıc approach to modelıng regional ground- 
water flow 2 Applicatıon to Owens Valley, Calıfornı Water Resources Research, v 26, no 7, p 1569-1581

Hall, W E , and MacKevett, E M , Jr , 1962, Geology and ore deposits of the Darwin quadrangle, Inyo County, Calıfornia U S Geological Survey Professional Paper 368, $87 \mathrm{p}$

Hammon, W D , 1912, Potash solutions in the Searles Lake region Mining Science, v 65, no 4, p 372-373

Hantush, M S , 1960, Modification of the theory of leaky aquifers Journal of Geophysical Research, v 65, no B11, p 37133725

Hardt, W F , 1980, Review of hydrologic information for adequacy in developing a water-management plan in the Owens Valley, southern Calıfornia, Appendix B of Owens Valley Ground Water Investıgation, Phase I Calıfornı Department of Water Resources, Southern District Report, 77 p

Hay, J M , 1964, Phillıpsite of salıne lakes and soils American Mineralogist, v 49, p 1366-1387

Hess, F L, and Larsen, E S , 1921, Contact-metamorphic tungsten deposits of the United States U S Geological Survey Bulletın $725, \mathrm{p}$ 268-274

Higgins, C T , Flynn, T , Chapman, R H, Trexler, D T, Chase, G R , Bacon, C F , and Ghusn, G, Jr , 1985, Geothermal systems of the Mono Basın-Long Valley regıon, eastern Calıfornıa and western Nevada Californı Division of Mines and Geology, Open-File Report 85-19 SAC, 159 p

Hollett, K J , 1987, Additional studies, in Rogers, L S , and others, Overview of water resources in Owens Valley, Californı U S Geological Survey Water-Resources Investıgatıons Report 864357, p 34-35

Hollett, K J , and Marie, J R , 1986, Simulation of the ground-water flow system and proposed withdrawals in the northern part of Vekol Valley, Arızona U S Geological Survey WaterResources Investigations Report 86-4340, 68 p

Hollett, K J , and Rogers, L S , 1987, Historical water-level fluctuatıons, 1971-84, in Rogers, L S and others, Overview of water resources in Owens Valley, Calıfornı U S Geological Survey Water-Resources Investigations Report 86-4357, p 30-33

Hopper, R H , 1947, Geologic section from the Sierra Nevada to Death Valley, Calıfornıa Geological Society of Amenca Bulletın, v 58, p 393-432

Howard, N W , 1979, Subsurface correlation of Tertiary-Quaternary desert alluvial deposits, northern Yucca Flat, Nevada Geological Society of Amenca, Abstracts with Programs, v 11, no $3, \mathrm{p} 85$

Hubbs, Carl, and Miller, R P , 1948, The Great Basin University of Utah Bulletın, v 38, no 20, p 18-166

Huber, N K, 1981, Amount and tımıng of late Cenozoic uplift and tilt of the central Sierra Nevada, Calıformia-Evidence from the upper San Joaquin River basin U S Geological Survey Professional Paper 1197, $28 \mathrm{p}$

Huber, N K , and Rinehart, C D , 1965, Geologic map of the Devil's Postpıle quadrangle, Sierra Nevada, Calıfornı U S Geological Survey Geologic Quadrangle Map GQ-437, scale 1 62,500

Hunt, C B , 1974, Natural regions of the United States and Canada San Francisco, Freeman, $725 \mathrm{p}$

Hunt, C B , and Mabey, D R , 1966, Stratıgraphy and structure of Death Valley, Calıfornıa U S Geological Survey Professıonal Paper 494-A, 162 p

Hunt, C B , and Robinson, T W , 1960, Possible interbasin circulation of ground water in the southern part of the Great Basin
U S Geological Survey Professional Paper 400-B, p B273B274

Hutchıson, W R , 1986a, Updated water budgets in Owens Valley Inyo County Water Department Report 86-2, $18 \mathrm{p}$

1986b, Estımation of baseflow Owens River at Keeler Bridge Inyo County Water Department Report 86-4, 24 p

Jachens, R C , and Griscom, A, 1986, An isostatic residual grav1ty map of Calıfornı-A residual map for interpretation of anomalies from intracrustal sources, in Hinze, W J , ed, The utılity of regional gravity and magnetıc anomaly maps Soc1ety of Exploration Geophysicists, p 347-360

Jannık, N O , Phillıps, Fred, Smıth, G I , Elmore, Davıd, and Kubık, Peter, 1987, Hydrologic response to climatic changes in a closed-basın lake system Paleo-Owens River system, Calıfornıa Eos, Transactions of the American Geophysical Unıon, Abstracts, v 68, no 44, p 1270

Jennıngs, C W , compıler, 1975, Fault map of Calıfornı Calıfornia Division of Mines and Geology, map no 1, scale 1750,000

Johnson, E A , 1968, Structural geology of the south Mazourka Canyon area, Inyo County, Calıfornı San Jose, Calıfornıa State University, M S thesis, $61 \mathrm{p}$

Kahle, J E , Bryant, W A, and Hart, E W , 1986, Fault rupture associated with the July 21,1986 , Chalfant Valley earthquake, Mono and Inyo Countıes, Calıfornıa Calıfornı Geology, v 39, no 11 , p 243-245

Kane, M F , and Pakıser, L C, 1961, Geophysical study of the subsurface structure in southern Owens Valley, Calıfornı Geophysics, v 26, no 1, p 12-26

Kırk, E , 1918, Stratıgraphy of the Inyo Range, in Knopf, Adolf, A geologic reconnaissance of the Inyo Range and the eastern slope of the southern Sierra Nevada, California U S Geological Survey Professional Paper 110, p 19-48

Knopf, Adolf, 1918, A geologic reconnaissance of the Inyo Range and the eastern slope of the southern Sierra Nevada, Calıfornia, with a section on Stratıgraphy of the Inyo Range, by $\mathrm{E}$ Kırk U S Geological Survey Professional Paper 110,130 p

Krauskopf, K B , 1971, Geologic map of the Mount Barcroft quadrangle, Calıfornı-Nevada U S Geological Survey Geo$\log _{1 \mathrm{c}}$ Quadrangle Map GQ-960, scale 162,500

Krauskopf, K B , and Bateman, P C , 1977, Geologic map of the Glass Mountain quadrangle, Mono County, Calıfornıa, and Mineral County, Nevada U S Geological Survey Geologic Quadrangle Map GQ-1099, scale 1 62,000

Lajoie, K R , 1968, Late Quaternary stratıgraphy and geologic history of Mono Basın, eastern Calıfornıa Berkeley, Unıversıty of Calıfornı, $\mathrm{Ph} \mathrm{D}$ dissertation, $271 \mathrm{p}$

Langbein, J O , Linker, M F , and Tupper, D L, 1985, Steady decrease in extension rate withın the Long Valley caldera, eastern Calıfornia, 1983-1985 Eos, Transactions of the American Geophysıcal Unıon, Abstracts, v 66, no 46, p 852

Langenheim, V A M , Donahoe, J L , and McKee, E H, 1982a, Geologic map of the Andrews Mountain, Mazourka, and Paiute roadless areas, Inyo County, Calıfornıa U S Geological Survey Miscellaneous Field Studies Map MF-1492-A, scale 162,500

1982b, Geologic map of the Laurel-McGee and Wheeler Ridge roadless areas, Inyo and Mono Counties, Calıfornia U S Geological Survey Miscellaneous Field Investıgatıons Map MF-1411-A, scale 162,500 
Lee, C H , 1912, An intensive study of the water resources of a part of Owens Valley, Calıfornıa U S Geological Survey WaterSupply Paper 294, 135 p

1932, Report on the physical and economic limits of the underground water resources of Owens Valley Los Angeles Department of Water and Power, unpublished report, $23 \mathrm{p}$

Lee, W T , 1906, Geology and water resources of Owens Valley, Calıfornıa U S Geological Survey Water-Supply Paper 181, $28 \mathrm{p}$

Lemmon, D M , 1941, Tungsten deposits in the Sierra Nevada near Bıshop, Calıfornıa U S Geological Survey Bulletın 931-E, p 79-104

Lienkaemper, J J , Pezzopane, S K , Clark, M M , and Rymer, M J , 1987, Fault fractures formed in association with the 1986 Chalfant Valley, Calıfornıa, earthquake sequence, prelımınary report Bulletın of Seismological Society of America, v 77, no $1, \mathrm{p} 297-305$

Lohman, S W , 1979, Ground-water hydraulıcs US Geologıcal Survey Professional Paper 708, $70 \mathrm{p}$

Lopes, T J , 1988, Hydrology and water budget of Owens Lake, Calıfornia Reno, University of Nevada, Desert Research Inst1tute, Water Resources Center Publication 41107, 104 p

Los Angeles [city of] Board of Public Service Commissioners, 1916 Complete report on construction of the Los Angeles Aqueduct Calıfornia Department of Publıc Service, city of Los Angeles, $331 \mathrm{p}$

Los Angeles Department of Water and Power, 1972, Report on water resources management plan, Owens Valley groundwater basin $160 \mathrm{p}$

-1974, Groundwater quality in the Owens Valley Departmental report by the Sanitary Engineering Division, Los Angeles Department of Water and Power, $88 \mathrm{p}$

1976, Increased pumping of the Owens Valley groundwater basin Final Environmental Impact Report, v 2, $125 \mathrm{p}$

1978, Increased pumping of the Owens Valley groundwater basin Draft Environmental Impact Report 152 p , 8 appendixes

-1979 , Increased pumping of the Owens Valley groundwater basin Final Environmental Impact Report, v 1, $253 \mathrm{p}$

Lubetkın, K C , 1980, Late Quaternary actıvity along the Lone Pıne fault, Owens Valley, Calıfornia Stanford, Calıf, Stanford University, M S thesis, $85 \mathrm{p}$

Lubetkın, K C , and Clark, M M , 1985, Late Quaternary actıvity along the Lone Pıne fault, eastern Calıforma, in Stein, R S , and Buckman, R C , eds , Proceedings of Workshop 27 on the Borah Peak, Idaho, earthquake U S Geological Survey Open-File Report 85-290-A, p 118-140

1987, Late Quaternary fault scarp at Lone Pine, Calıfornıa, location of oblique slip during the great 1872 earthquake and earlier earthquakes Geological Society of Amenca, Central Field Guide, Cordilleran Section, p 151-156

Mankınen, E A , Gromme, C S , Dalrymple, G B , Lanphere, M A , and Balley, R A, 1986, Paleomagnetısm and K-Ar ages of volcanic rocks from Long Valley caldera, Calıfornı Journal of Geophysical Research, v 91, no B1, p 633-652

Marliave, Chester, 1934, Geological report on Tinemaha Dam, situated in Owens River in Inyo County Sacramento, Cal1fornia Department of Water Resources Report, $9 \mathrm{p}$

Martel, S J , 1984a, Structure of the Owens Valley fault zone near Poverty Hills, Owens Valley, Calıfornıa [abs ] Geologıcal Society of America, Abstracts with Programs, v 16, no 6, p 585

1984b, Late Quaternary activity on the Fish Springs fault, Owens Valley fault zone, Calıfornı Stanford, Calıf, Stanford Unıversity, M S thesis, $100 \mathrm{p}$

Matthes, F E , and Fryxell, F, eds , 1950, Sequoia Natıonal Park, a geological album Berkeley, Unıversity of Calıfornıa Press, $136 \mathrm{p}$

Mayo, E B , 1934, The Pleistocene Long Valley lake in eastern Calıfornıa Science, v 80, no 2065, p 95-96

1941, Deformation in the interval Mt Lyell-Mt Whitney Geological Society of America Bulletın, v 52, no 7, p 10011054

1947, Structure plan of the southern Sierra Nevada, Cal1fornıa Geological Society of America Bulletın, v 58, no 6, p 495-504

McKee, E H , 1971, Tertiary 1gneous chronology of the Great Basin of Western United States-Implications for tectonic models Geological Society of America Bulletın, v 82, no 12, p 3497-3502

McKee, E H , Conrad, J E , Kılburn, J E, McCarthy, J H , Jr , Blakely, R J , and Close, T J , 1985, Mineral resources of the Inyo Mountains wilderness study area, Inyo County, Calıfornaa U S Geological Survey Bulletın 1708-A, 18 p

McKee, E H , Diggles, M F , Donahoe, J L , and Ellıtt, G , 1982, Geologic map of the White Mountains wilderness and roadless areas, Calıfornia and Nevada U S Geological Survey Miscellaneous Field Studies Map MF-1361-A, scale 1 62,500

McKee, E H , Noble, D C , and Silberman, M L , 1970, Middle Miocene hiatus in volcanic activity in the Great Basin area of the Western United States Earth and Planetary Science Letters, $v$ 8, no 2, p 93-96

McPherson, J G , Shanmugam, Ganapathy, and Moila, R J , 1987, Fan deltas and braid deltas Varietıes of coarse-grained deltas Geological Society of America Bulletın, v 99, no 3, p 331-340

Meinzer, O E , 1922, Map of the Pleistocene lakes of the Basın and Range province and its significance Geological Society of America Bulletın, v 33, no 9, p 541-552

Mernam, C W , 1963, Geology of the Cerro Gordo mineral district, Inyo County, Calıfornıa U S Geological Survey Professional Paper 408, $83 \mathrm{p}$

Miall, A D , 1981, Alluvial sedımentary basıns Tectonıc settıng and basin architecture, in Miall, A D, ed , Sedimentation and tectonics in alluvial basins Geological Association of Canada, Paper 23, p 1-33

1984, Principles of sedımentary basın analysıs New York, Sprınger-Verlag, $490 \mathrm{p}$

Miller, R H , 1976, Revision of upper Ordovician, Silurian, and lower Devonian stratıgraphy, southwestern Great Basin Geological Society of America Bulletın, v 87, no 7, p 961968

Miller, R R , 1946, Correlation between fish distribution and Pleistocene hydrography in eastern California and southwestern Nevada, with a map of the Pleistocene waters Journal of Geology, v 54, no 1, p 43-53

Moore, J G , 1963, Geology of the Mount Pinchot quadrangle, southern Sierra Nevada, Calıfornia US Geological Survey Bulletın 1130, $152 \mathrm{p}$

Moore, J G , and Dodge, F C W , 1980, Late Cenozorc volcanic rocks of the southern Sierra Nevada, Calıfornı 1 Geology 
and petrology Geological Society of America Bulletın, pt 2, v 91, no 9,p 1995-2038

Morıng, B C , 1986, Reconnaissance surficial geologic map of northern Death Valley, Calıfornia and Nevada U S Geological Survey Miscellaneous Field Investigations Map MF-1770, scale 162,500

Nelson, C A , 1962, Lower Cambrian-Precambrian succession, White-Inyo Mountains, Californıa Geological Society of America Bulletın, v 73, no 1, p 139-144

1966a, Geologic map of the Blanco Mountain quadrangle, Inyo and Mono Countıes, Calıfornı U S Geological Survey Geologic Quadrangle Map GQ-529, scale 1 62,500

-1966b, Geologic map of the Waucobı Mountain quadrangle, Inyo County, Calıfornı U S Geological Survey Geologic Quadrangle Map GQ-528, scale 1 62,500

Nelson, C A , Oertel, G , Christıe, J M , and Sylvester, A G , 1978, Geologic map of Papoose Flat pluton, Inyo Mountains, Calıfornia Geological Society of America, map sheet MC20, scale $132,000,3$ sheets

Neuman, S P , 1975, Analysis of pumping test data from anısotropic unconfined aquifers considering delayed gravity response Water Resources Research, v 11, no 2, p 329-342

Neuman, S P , and Witherspoon, P A , 1971, Field pumping tests, in Sea-water intrusion Aquitards in the coastal ground water basın of Oxnard plain, Ventura County, Calıfornı Calıfornı Department of Water Resources Bulletın No 63-4, p 63-85

Nolan, T B , 1943, The Basın and Range province in Utah, Nevada, and Calıfornı US Geological Survey Professional Paper 197-D, p D141-D196

Nork, D M , 1987, The analysis of water-level fluctuations in a shallow, unconfined aquifer, Owens Valley, Calıfornı Reno, University of Nevada, M S thesis, $61 \mathrm{p}$

Oakes, E H , 1987, Age and rates of displacement along the Furnace Creek fault zone, northern Death Valley, Calıfornıa [abs ] Geological Society of America, Abstracts with Programs, v 19 , no 6, p 437

Oliver, H W , 1977, Gravity and magnetic investigations of the Sierra Nevada batholith, Calıfornia Geological Society of America Bulletın, v 88, no 3,p 445-461

Oliver, H W , and Robbins, S L , 1982, Bouguer gravity map of Calıfornia, Fresno sheet Calıfornia Division of Mines and Geology, scale $1250,000,23 \mathrm{p}$

Pakıser, L C , 1960, Transcurrent faultıng and volcanısm in Owens Valley, Calıfornıa Geological Society of America Bulletın, v 71, no 2, p 153-160

Pakiser, L C , and Kane, M F , 1962, Geophysical study of Cenozo1c geologic structures of northern Owens Valley, Calıfornıa Geophysıcs, v 27, no 3, p 334-342

Pakıser, L C, Kane, M F , and Jackson, W H , 1964, Structural geology and volcanısm of Owens Valley region, CalıfornıA geophysical study US Geological Survey Professional Paper 438, $65 \mathrm{p}$

Pistrang, M A, and Kunkel, Fred, 1964, A brief geologic and hydrologic reconnaissance of the Furnace Creek Wash area, Death Valley National Monument, Calıfornıa U S Geolog1cal Survey Water-Supply Paper 1779-Y, 35 p

Prodehl, Claus, 1979, Crustal structure of the Western United States U S Geological Survey Professional Paper 1034, $74 p$

Putnam, W C , 1950, Moraine and shorelıne relationshıps at Mono Lake, Calıfornıa Geologıcal Society of Amerıca Bulletın, v 61 , no $1, \mathrm{p} 115-122$

Rachockı, A H , 1981, Alluvial fans New York, John Wıley, 157 p

Richardson, L K , 1975, Geology and the Alabama Hills Reno, University of Nevada, M S thesis, $146 \mathrm{p}$

Rınehart, C D , and Ross, D C , 1957, Geologic map of the Casa Diablo quadrangle US Geological Survey Geologic Quadrangle Map GQ-99, scale 162,500

-1964 , Geology and mineral deposits of the Mount Morrison quadrangle, Sierra Nevada, Calıfornıa U S Geologıcal Survey Professional Paper 385, 106 p

Roberts, R J , 1968, Tectonic framework of the Great Basın, in A coast to coast tectonic study of the United States Rolla, Unıversity of Missourı, Journal, no 1, p 101-119

Ross, D C , 1962, Correlation of granitic plutons across faulted Owens Valley, Calıfornıa US Geological Survey Professional Paper 450-D, p D86-D88

1965 , Geology of the Independence quadrangle, Inyo County, Calıfornı U S Geological Survey Bulletın 1181-O, 64 p

1967, Generalized geologic map of the Inyo Mountains region, Calıfornia US Geological Survey Miscellaneous Geologic Investıgations Map I-506, scale 1 125,000

1969 , Descriptive petrography of three large granitic bodies in the Inyo Mountains, Calıfornı U S Geologıcal Survey Professional Paper 601, $47 \mathrm{p}$

Russel, Steven, and Nokleberg, Warren, 1977, Superımposition and tıming of deformations in the Mount Morrison roof pendant and in the central Sierra Nevada, Calıfornia Geological Society of America Bulletın, v 88, no 3, p 335345

Russell, I C , 1889, Geological history of Mono Valley, Calıfornıa U S Geological Survey Eighth Annual Report, p 261394

Savage, J C , 1985, Deformation of Long Valley caldera, Calıfornı, 1982-1985 Eos, Transactions of the American Geophysical Union, Abstracts, v 66, no 46, p 852

Schultz, J R, 1937, A late Cenozoic vertebrate fauna from the Coso Mountains, Inyo County, Calıfornı Carnegie Instıtutıon of Washington, Publication 487, p 75-109

Schweig, E S , III, 1986, The inception of Basin and Range tectonics in the region between Death Valley and the Sierra Nevada, Calıfornıa Geological Society of America, Abstracts with Programs, v 18, no 2, p 181

Segall, P, and Pollard, D D , 1980, Mechanics of discontınuous faults Journal of Geophysical Research, $v$ 85, no B8, p 4337-4350

Sharp, R P , 1972, Pleıstocene glaciation, Brıdgeport Basın, Cal1fornıa Geological Society of America Bulletın, v 83, no 8, p 2233-2260

Sharp, R P, and Bırman, J H , 1963, Additions to classical sequence of Pleistocene glaciatıons, Sierra Nevada, Calıfornıa Geological Society of Amenca Bulletın, v 74, no 8, p 10791086

Sharp, R V , and Clark, M M , 1972, Geologic evidence of previous faultıng near the 1968 rupture on the Coyote Creek fault in The Borrego Mountain earthquake of April 9, 1968 U S Geological Survey Professional Paper 787, p 131-140

Sheridan, M F , 1965, The mineralogy and petrology of the Bishop Tuff Stanford, Calıf, Stanford University, Ph D dissertation, $165 \mathrm{p}$

Sherlock, D G , and Hamılton, W , 1958, Geology of north half of 
the Mt Abbot quadrangle, Sierra Nevada, Calıfornıa Geological Society of America Bulletin, v 69, no 10, p 12451268

Simpson, M R , and Duell, L F W , Jr , 1984, Design and implementation of evapotranspiration measuring equipment for Owens Valley, Calıfornıa Groundwater Monitoring Review, v 4, no 4, p 155-163

Sımpson, R W , Jachens, R C , and Blakely, R J , 1983, AIRYROOT A Fortran program for calculatıng 1sostatic regional anomalies from digital topography U S Geological Survey Open-F1le Report 83-883, 66 p

Smith, G I , 1962, Subsurface stratıgraphy of late Quaternary deposits, Searles Lake, Calıfornia, A summary U S Geological Survey Professional Paper 450-C, p C65-C69

1979, Subsurface stratıgraphy and geochemistry of late Quaternary evapontes, Searles Lake, California, with a sectıon on Radiocarbon ages of stratıgraphic units by Minze Stuiver and George I Smith U S Geological Survey Professional Paper 1043, $122 \mathrm{p}$

Smith, G I, Barczak, V J, Moulton, G F, and Liddicoat, J C , 1983, Core KM-3, a surface-to-bedrock record of late Cenozoic sedimentation in Searles Valley, Calıfornia U S Geological Survey Professional Paper 1256, $24 \mathrm{p}$

Smith, G I , and Pratt, W P , 1957, Core logs from Owens, Chına, Searles, and Panamınt Basıns, Calıfornıa US Geologıcal Survey Bulletın 1045-A, 62 p

Snyder, C T , Hardman, G, and Zdenek, F F , 1964, Pleıstocene lakes of the Great Basin U S Geological Survey Miscellaneous Geologic Investıgatıons Map I-416, scale 1 1,000,000

Sorenson, S K , Miller, R F , Welch, M R , Groeneveld, D P , and Branson, F A , 1989, Estımatıng soll matric potential in Owens Valley, Calıfornia U S Geological Survey Water-Supply Paper 2370-C, $18 \mathrm{p}$

Sorey, M L, 1985, Evolution and present state of hydrothermal system in Long Valley caldera Journal of Geophysical Research, v 90, no B13, p 11,219-11,228

Sorey, M L, Lew1s, R E , and Olmsted, F H , 1978, The hydrothermal system of Long Valley caldera, Calıfornia U S Geological Survey Professional Paper 1044-A, $60 \mathrm{p}$

Spurr, J E , 1903, Nevada south of the fortieth parallel and adjacent portions of Calıfornia U S Geological Survey Bulletın $208,229 \mathrm{p}$

Stevens, C H , and Olson, R C , 1972, Nature and significance of the Inyo thrust fault, eastern Calıfornia Geological Society of America Bulletın, $v$ 83, no 12, p 3761-3768

Stewart, J H , 1967, Possible large right-lateral displacement along fault and shear zones in the Death Valley-Las Vegas area, Calıfornıa and Nevada Geological Society of America Bulletın, $v$ 78, no 2,p 131-142

1971, Basin and Range structure A system of horsts and grabens produced by deep seated extension Geological Soc1ety of America Bulletın, v 82, no 4,p 1019-1044

1978, Basin and Range structure in western North America A review, in Smith, R B , and Eaton, G P, eds, Cenozoic tectonics and regional geophysics in the western Cordillera Geological Society of America Memoir 152, p 1-31

1985, East-trending dextral faults in the western Great Basin An explanation for anomalous trends of pre-Cenozoic strata and Cenozoic faults Tectonics, v 4, no 6,p 547-564

Stewart, J H , Ross, D C , Nelson, C A , and Burchfiel, B C , 1966,
Last Chance thrust-a major fault in the eastern part of Inyo County, Calıfornıa U S Geological Survey Professional Paper 550-D, p D23-D34

Stınson, M C , 1977a, Geology of the Haiwee Reservolr 15-mınute quadrangle, Inyo County, Calıfornı Calıfornı Division of Mines and Geology, map sheet 37, scale 162,500

1977b, Geology of the Keeler 15-minute quadrangle, Inyo County, Calıfornıa Calıfornia Division of Mines and Geology, map sheet 38 , scale 162,500

Stone, Paul, Conley, D E, and Stevens, C H , 1979, Late Permıan orogenic strata in the southern Inyo Mountains, Calıfornia Geological Society of America, Abstracts with Programs, v 11 , no 3 , p 130

Stone, Paul, and Stevens, C H , 1987, Stratıgraphy of the Owens Valley Group (Permian), southern Inyo Mountains, Calıfornıa U S Geological Survey Bulletın 1692, 19 p

Sylvester, A G , 1985, Crustal tıltıng in Long Valley, Calıfornıa U S Geological Survey Open-File Report 85-664, 40 p

Sylvester, A G , Oertel, G , Nelson, C A , and Chrıstıe, J M , 1978, Papoose Flat pluton a granitıc blister in the Inyo Mountains, Calıfornıa Geological Society of America Bulletın, v 89, no 8 , p 1205-1219

Theis, C V , 1935, The relation between the lowering of the prezometric surface and the rate and duration of discharge of a well using groundwater storage Eos, Transactions of the American Geophysical Union, v 2, p 519-524

Thornbury, W D , 1965, Regional geomorphology of the United States New York, John Wiley, 609 p

Thornthwaite, C W , 1931, The climates of North America according to a new classification Geographical Review, v 21, p 633-655

Tolman, C F , 1937, Groundwater New York, McGraw-Hill, 593 p

Trowbridge, A C , 1911, The terrestrial deposits of Owens Valley, Calıfornia Journal of Geology, v 19, no 8, p 706-747

Twenhofel, W H , and McKelvey, V E , 1941, Sedıments of freshwater lakes American Association of Petroleum Geologists Bulletın, v 25, no 5, p 826-849

Tyson, N H , and Weber, E M , 1964, Groundwater management for the Natıon's future Computer simulation of groundwater basins American Society of Civil Engineers, Hydraulics Division Journal, v 90, no HY4, p 59-77

US Bureau of Land Management, 1976a, Darwin Hills quadrangle U S Bureau of Land Management Surface Management Map, scale 1100,000

1976b, Salıne Valley quadrangle U S Bureau of Land Management Surface Management Map, scale 1 100,000

1976c, Benton Range quadrangle US Bureau of Land Management Surface Management Map, scale 1100,000

1978a, Three Rivers quadrangle U S Bureau of Land Management Surface Management Map, scale 1 100,000

1978b, Mount Whitney quadrangle U S Bureau of Land Management Surface Management Map, scale 1 100,000

1978c, Bishop quadrangle U S Bureau of Land Management Surface Management Map, scale 1 100,000

U S Environmental Protection Agency, 1977a, Natıonal interım prımary drınkıng water regulations Washıngton, U S Env1ronmental Protection Agency Report EPA-570/9-76-003, $159 \mathrm{p}$

1977b, Natıonal secondary drınkıng water regulatıons Washıngton Register, v 42, no 62, p 17143-17147 
1986, Quality criteria for water Washıngton, U S Envıronmental Protection Agency, $256 \mathrm{p}$

U S Geological Survey, 1983a, Aeromagnetıc map of the central part of the Inyo National Forest, Calıfornı U S Geological Survey Open-File Report 83-655, scale 1250,000

$1983 \mathrm{~b}$, Aeromagnetic map of the White and Inyo Mountains, Calıfornia and Nevada U S Geological Survey OpenFile Report 83-656, scale 1250,000

$1983 \mathrm{c}$, Aeromagnetic map of the northern part of the Inyo Natıonal Forest, Calıfornı and Nevada U S Geological Survey Open-File Report 83-654, scale 1250,000

U S Salınıty Laboratory, 1954, Salıne and alkalı solls U S Department of Agriculture Handbook no 60,160 p

Van Wormer, J D, and Ryall, A S , 1980, Seismicity related to structure and active tectonic processes in the western Great Basın, Nevada and eastern Calıfornıa, in Proceedıngs of conference $\mathrm{X}$ earthquake hazards along the Wasatch SierraNevada frontal fault zones U S Geological Survey OpenFile Report 80-801, p 37-61

Waitt, R B , Jr , 1981, Concepts of classification and nomenclature for surficial deposits U S Geological Survey Open-File Report 81-28, $26 \mathrm{p}$

Walcott, C D , 1897, The post-Pleistocene elevation of the Inyo Range, and the lake beds of Waucobi embayment, Inyo County, Calıformia Journal of Geology, v 5, no 4, p 340-348

Wallace, R E , 1984, Patterns and tımıng of late Quaternary faulting in the Great Basin province and relation to some regional tectonic features Journal of Geophysical Research, v 89, no B7, p 5763-5769

Weiss, J S , and Williamson, A K , 1985, Subdivision of thick sedimentary units into layers for simulation of ground-water flow Groundwater, v 23, no 6, p 767-774

Welch, T C , 1979, Superposed Mesozorc deformations in the southern White Mountains, eastern Calıfornıa Geological Society of America, Abstracts with Programs, v 11, no 3 , p 134 135

Willıams, D E , 1966, Water resources development study for proposed Los Angeles Aqueduct second barrel Los Angeles Department of Water and Power unpublished report, $62 \mathrm{p}$

1969, Prelıminary geohydrologic study of a portion of the Owens Valley ground-water reservoir Socorro, New Mexico Institute of Minıng and Technology, $\mathrm{Ph} \mathrm{D}$ dissertation, $194 \mathrm{p}$

-1970 , Use of alluvial faults in the storage and retention of ground water Groundwater, v 8, no 5, p 25-29

Williams, P B , 1978, Changes in the Owens Valley shallow groundwater levels from 1970 to 1978 Prepared for the Inyo County Board of Supervisors, $50 \mathrm{p}$

Williams, T R, and Bedınger, M S , 1984, Selected geologic and hydrologic characteristics of the Basin and Range province, Western United States, Pleistocene lakes and marshes U S Geological Survey Miscellaneous Geologic Investıgatıons Map I-1522-D, scale $12,500,000$

Wood, S H , 1983, Chronology of late Plesstocene and Holocene volcanics, Long Valley and Mono Basin geothermal areas, eastern Calıfornıa U S Geological Survey Open-File Report 83-747, $77 \mathrm{p}$

Wood, W W , and Fernandez, L A , 1988, Volcanic rocks, in Back, W, Rosenshein, J S , and Seaber, P R, eds, Hydrogeology, v 0-2 of The Geology of North America Boulder, Colo, Geological Society of America, p 353-365

Wright, L A , and Troxel, B W , 1967, Limitations on right-lateral, strike-slıp displacement, Death Valley and Furnace Creek fault zones, Calıfornia Geological Society of America Bulletın, v 78, no 8, p 933-950

Yen, Chung-Cheng, 1985, A determınıstic-probabilıstıc modelıng approach applied to the Owens Valley groundwater basin Irvine, Unıversıty of Calıfornı, School of Engıneerıng, Ph D dissertation, $199 \mathrm{p}$ 